\title{
LIETUVOS KARIUOMENĖS ŠARVUOTIEJI TRAUKINIAI 1920-1935 M.
}

\author{
Ltn. dr. Andriejus Stoliarovas \\ Mechanizuotoji péstininkų brigada „Geležinis Vilkas“
}

\section{IVADAS}

Šarvuotasis traukinys - tai visiškai arba iš dalies šarvuotas ir ginkluotas traukinys, skirtas kovos ir paramos veiksmams geležinkelio ruože vykdyti. Jị sudare dvi pagrindinès dalys: kovinè ir bazinè. Kovinẻ dalis, kurią sudarẻ garvežys, keletas artilerijos platformų (vagonų), ginkluotų kulkosvaidžiais, patrankomis, haubicomis, ir keletas kulkosvaidžių vagonų, ginkluotų kulkosvaidžiais, buvo skirta dalyvauti kautynèse. Bazinę dalị, kuri mūšiuose nebuvo naudojama, skirtą apsaugai ir paramai užtikrinti, sudarė keliolika keleivinių vagonų, skirtą kariams gyventi, mokytis, dirbti, maitintis, ilsètis, gydytis, taip pat keliolika specialiosios paskirties prekinių vagonų, kuriuose buvo irrengti sandèliai ir dirbtuvès, ir kontrolinių platformų su geležinkelio medžiaga.

Šie traukiniai buvo plačiai naudojami ịvairių šalių kariuomenèse nuo $\mathrm{XIX}$ a. antrosios puses iki XX a. vidurio. Jie dalyvavo ir svarbiausiuose XIX-XX a. karuose: JAV pilietiniame (1861-1865 m.), Prancūzijos-Prūsijos (1870-1871 m.), Anglų-būrų (1899-1902 m.), Rusijos pilietiniame (1917-1922 m.), Pirmajame ir Antrajame pasauliniuose (1914-1918 m. ir 1939-1945 m.), Lenkijos-Sovietų Rusijos (1919-1921 m.). Laikotarpiu tarp dviejų pasaulinių karų îvairių šalių kariuomenès turejo ir šarvuotųju traukinių. Ne išimtis ir Baltijos valstybès - Lietuva, Latvija ir Estija, bet kaimynès anksčiau pradejjo tuo rūpintis, turejjo daugiau ir ilgiau naudojamų šarvuotụjų traukinių.

Atkurtos Lietuvos Respublikos kariuomenès kariai pirmą kartą su šarvuotaisiais traukiniai susidūrẻ Nepriklausomybès kovų (19191920 m.) metu, nes jų, taip pat šarvuotųjų automobilių ir net tankų vietos fronte turejjo priešų kariuomenès - bolševikų, bermontininkų ir 
lenkų ${ }^{1}$. Dalis jų su šarvuotaja karo technika buvo susipažinę tarnaudami dar carinès Rusijos imperijos, baltagvardiečių ir kitose kariuomenėse. Pirmieji šarvuotieji traukiniai Lietuvos kariuomeneje pradèti naudoti pačioje Nepriklausomybès kovų pabaigoje ir buvo naudojami iki XX a. 4-ojo dešimtmečio pabaigos.

Šiame straipsnyje siekiama atskleisti Lietuvos Respublikos kariuomenès šarvuotųjų traukinių istorinę raidą 1920-1935 m. Šiam tikslui pasiekti keliami trys uždaviniai: 1) išnagrinèti šarvuotųjų traukinių dalinio atsiradimo aplinkybes, jo formavimo ypatumus ir kovines funkcijas, užduotis kovų su lenkais metu; 2) išanalizuoti šarvuotųjų traukinių struktūrą, ginkluotę ir naudojimo taikos metu ypatumus; 3) apžvelgti šarvuotųjų traukinių dalinio funkcionavimo ypatumus aptariant Estijos ir Latvijos kariuomenių šarvuotųjų traukinių dalinių struktūrą.

Pirmiausia šio tyrimo aktualumą lèmé istoriografinè situacija, kurioje šarvuotųjų traukinių tema palyginti menkai tyrinèta ir pristatyta tik bendrame kovinių dalinių ir karinès technikos istoriniame kontekste, nors informatyvios ikonografinès medžiagos (nuotraukų ir negatyvų) netrūksta. Todèl straipsnio autorius šia tema 2015 m. parengè kilnojamąją parodą "Lietuvos kariuomenès šarvuotieji traukiniai 1920-1935 m.“ ir $2016 \mathrm{~m}$. brošiūrą „Lietuvos kariuomenès šarvuotieji traukiniai 1920-1940 m.“

Daugiausia ikonografinès medžiagos yra saugoma Lietuvos archyvuose, bibliotekose ir muziejuose, t. y. Lietuvos nacionalinès Martyno Mažvydo bibliotekos Retų knygų ir rankraščių skyriaus Zenono Ivinskio kolekcijoje, Lietuvos centrinio valstybės archyvo Fotonuotraukų skyriuje, Lietuvos nacionalinio, Geležinkelių, Lietuvos aviacijos ir Vytauto Didžiojo karo muziejų rinkiniuose ir privačiose kolekcijose.

Pagrindinė šia tema dokumentinè medžiaga saugoma Lietuvos centriniame valstybès archyve: Kariuomenès tiekimo valdybos (f. 1), Šarvuočių rinktinès (f. 828), Kariuomenès štabo (f. 929) fonduose, Krašto apsaugos ministerijos įstaigų ir karinių dalinių asmens sudèties dokumentų kolekcijoje (f. 930), Karo technikos valdybos (f. 1364), Artilerijos inspekcijos (f. 1373) fonduose, taip pat jau minètoje Lietuvos nacionalinès Martyno

1 Z. Ivinskis, Šarvuočių rinktinès istorija: rinktinès 15-os metų sukakčiai pažymèti nuo 1920.VII.14 iki 1935.VII.14, Lietuvos nacionalines Martyno Mažvydo bibliotekos Retu knygu ir rankraščiu skyriaus kolekcijos (toliau - LNMMB RK RSK), f. 29-697, 1. 65. 
Mažvydo bibliotekos Retų knygų ir rankraščių skyriaus Zenono Ivinskio kolekcijoje (f. 29).

Rengiant tekstą buvo aktualūs aptariamojo laikotarpio įstatymų igyvendinamieji teisès aktai - ísakymai kariuomenei ir instrukcijos ${ }^{2}$, atsiminimai $^{3}$. Ne mažiau vertingi jubiliejiniai leidiniai, skirti ịvairių kariuomenès dalinių sukaktims paminèti ${ }^{4}$, karių publikacijos ${ }^{5}$, ịvairūs lietuvių ${ }^{6}$ ir užsienio ${ }^{7}$ istorikų mokslo darbai. Deja, istoriografija nagrinejjama tematika yra menka, tad tyrime pasitelktos literatūrinès pozicijos yra pagalbinès, daugiau skirtos bendram kontekstui atskleisti.

Nors pati tema nesulaukè deramo istorikų dèmesio, šiame kontekste minètini istoriko Vytauto Lesčiaus darbai ${ }^{8}$, kuriuose ypatingas dèmesys skiriamas $1920 \mathrm{~m}$. laikotarpiui, kai buvo pradetas formuoti ir naudoja-

2 Instrukcija šarvuotiems traukiniams, Kaunas, [1922], d. I. Analogišką Šarvuotiems traukiniams instrukcija $1935 \mathrm{~m}$. turèjo parengti mjr. Adolfas Zubavičius, tačiau nežinoma, ar ji buvo parengta.

3 J. Dovydaitis, Svaidom ugnị ir plieną, Lietuvos sparnai, 1938, Nr. 3, p. 83; J. Baublys, Geležinkelių būrys Vilniaus kryptimi, Karys, 1961, Nr. 5, p. 139.

4 Karo technikos dalių dvidešimtmetis 1919-1939, Kaunas, 1939.

5 [J.] Kraucevičius, Plienu gaubta kariuomene, Karys, 1924, Nr. 44; [J.] Budzilas, Šarvuočių rinktinè, Mūsų žinynas, 1928, t. 15, Nr. 45; O. Žadvydas, Šarvuočių rinktinė, Karys, 1970, Nr. 7.

6 G. Ramoška, Lietuvos karo aviacija Nepriklausomybės karuose, Plieno sparnai, 1994, Nr. 2, p. 2-9; V. Orlov, Kauno tvirtoves istorija, Kaunas, 2007; V. Statkus, Lietuvos ginkluotos pajegos 1918-1940 m., Chicago, 1986; Lietuvos kariuomenés karininkai 1918-1953, Vilnius, 2002, t. 2; 2004, t. 4; 2005, t. 5; Г. И. Косаковский, Железные дороги Литвы, Вилнюс, 1975.

А. В. Шавровъ, Бронепоздпзда. Значеніе, вооруженіе, организація и тактика бронепоздпздовъ, Бълградъ, 1927; J. Soots, Estų Nepriklausomybès karai, Mūsų žinynas, 1931, t. XX, Nr. 73; T. Krawczak, J. Odziemkowski, Polskie pociagi pancerne w wojnie 1939, Warszawa, 1987; E. Andersons, The Military Situation in the Baltic States, Baltic Defence Review, 2001, vol. 2, no. 6; H. Walter, Soomusrongid, Laidoneri Muuseumi Aastaraamat, Tallinn, 2002, Nr. 1; T. Tojak, Vabadussõjas langenud soomusronglased, Laidoneri Muuseumi Aastaraamat, Tallinn, 2002, Nr. 1; M. Õu, T. Noormets, J. Pihlak, Eesti soomusrongid ja soomusronglased 1918-1941, Tallinn, 2003; T. Nõmm, Eesti suurtükivägi 1918-1940. Relvastus ja ülesehitus, Laidoneri Muuseumi Aastaraamat, Tallinn, 2004; М. Коломиец, Бронепоезда Великой Отечественной. „Сухопутные броненосиьы “ Красной Армии, Москва, 2010.

8 V. Lesčius, Lietuvos kariuomenè 1918-1920, Vilnius, 1998; V. Lesčius, Lietuvos kariuomené Nepriklausomybès kovose 1918-1920, Vilnius, 2004. 
mas šarvuotasis traukinys „Gediminas“. Autorius trumpai aprašo traukinio atsiradimo aplinkybes, organizacinę struktūrą ir personalo sudètị, nemažai dèmesio skiria traukinio naudojimo Nepriklausomybès kovose su lenkais atvejams. Tas pats pasakytina apie istoriko Arvydo Pociūno ${ }^{9}$ ir žurnalisto Vytauto Žeimanto darbus ${ }^{10}$. Pirmasis autorius bendrais bruožais nušviečia šarvuotųjų traukinių istorinę raidą, nuodugniau aptaria šarvuotę ir ginkluotę, karinio geležinkelio infrastruktūros kūrimo aplinkybes, antrasis - trumpai pristato šarvuotojo traukinio „Gediminas“ atsiradimo ir naudojimo kovose istoriją.

Ši straipsnị sudaro ịvadas, dèstomoji dalis, suskirstyta $\mathfrak{i}$ tris skyrius ir poskyrius, ir išvados.

\section{1. ŠARVUOTOJO TRAUKINIO „GEDIMINAS“ FORMAVIMAS NEPRIKLAUSOMYBÉS KOVŲ METU}

1919-1920 m. vykstant Nepriklausomybès kovoms strategiškai svarbus valstybei ir kariuomenei tapo geležinkelis. Tačiau, kad geležinkelių sistema funkcionuotų, reikejo ji atkovoti, apsaugoti ir parengti naudoti. Viena iš tokių priemonių tapo Lietuvos kariuomenè ir jos šarvuotųjų traukinių, taip pat geležinkelių daliniai. Taikos metu Lietuva turejjo gan platų geležinkelių tinklą, buvo pagrindinių geležinkelio linijų sankirtoje, rūpinosi jo struktūros materialiniu aprūpinimu, technine baze, kelių kokybe ir tarnautojais. Šarvuotieji traukiniai tapo geležinkelių sistemos dalimi ir buvo naudojami kovinèms ir paramos funkcijoms vykdyti.

\footnotetext{
9 A. Pociūnas, Buvo pasiruošę ginti Lietuvą... Šarvuoti traukiniai ir tankai, Tẻviškès žinios, 1989 m. gruodžio 5 d., Nr. 145; A. Pociūnas, Šarvuoti traukiniai Lietuvos kariuomeneje, Karys, 1994, Nr. 5; A. Pociūnas, Kauno tvirtovés gynyba 1915 metais, Kaunas, 2008. 10 V. Žeimantas, „Gediminas“ - pirmasis lietuvių šarvuotasis traukinys, Geležinkelininkas, 2000 m. rugpjūčio 1-15 d., Nr. 15; V. Žeimantas, Pirmajam Lietuvos šarvuotam traukiniui „Gediminas“ - 90 metų, <http://www.mokslasirtechnika.lt/2011-nr.1/2011nr.1.html> [žiūrèta: 201507 24].
} 


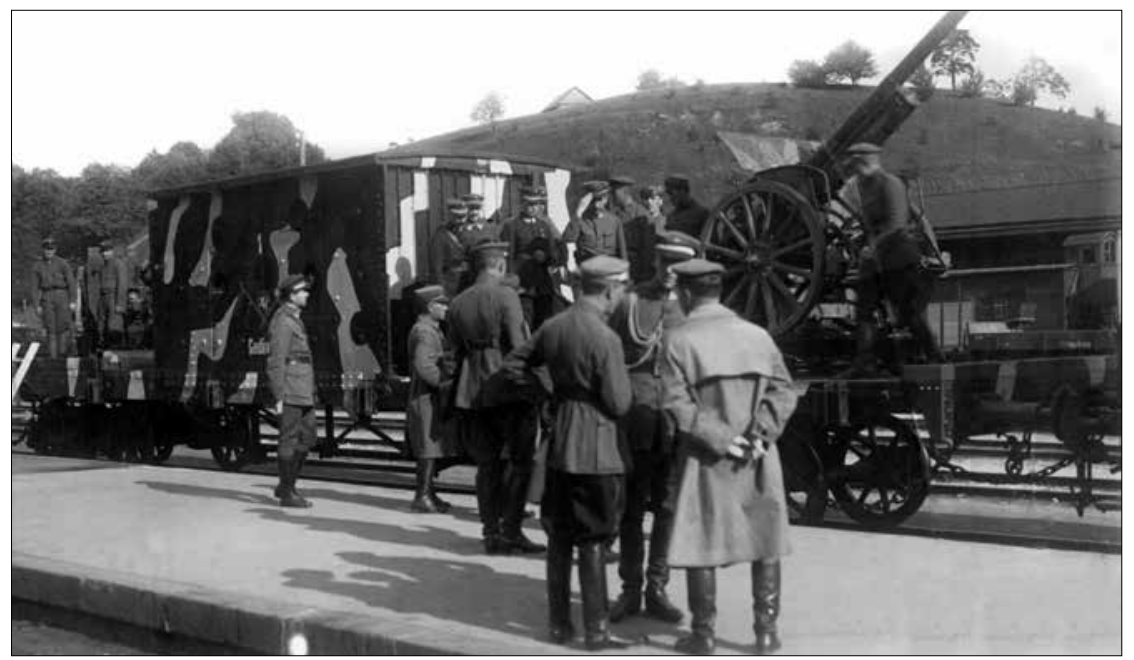

Lietuvos karinė vadovybė apžiūri šarvuotojo traukinio „Gediminas“ artilerijos platformą, ginkluotą $77 \mathrm{~mm} 1916 \mathrm{~m}$. lauko patranka (Vokietija). Kaunas, $1920 \mathrm{~m}$.

Ant platformos iš kairès: 1-as - šarvuotojo traukinio vado pareigas èjęs krn. / plk. ltn. Jonas Kraucevičcius, 3-ias - armijos vadas plk. ltn. Kazys Ladiga, 5-as - krašto apsaugos ministras, ėjęs vyriausiojo kariuomenès vado pareigas, plk. Itn. Konstantinas Žukas

Vytauto Didžiojo karo muziejaus nuotrauku rinkiniai (toliau - VDKM), Fa-14938

\subsection{Atsiradimo aplinkybès ir formavimo ypatumai}

1919 m. liepos 4 d. Vokietija perdavè siaurųjų ir plačiųjų geležinkelių tinklą Lietuvai. Jị sudarè rusų ir vokiečių ịvairiu laiku strateginiais ir prekybos tikslais nutiestos geležinkelių linijos, kurios ilgainiui buvo pertvarkytos ir pritaikytos krašto reikmèms. 1919-1920 m. Lietuvoje buvo per $1000 \mathrm{~km}$ plačiojo (1435 mm pločio) ir siaurojo (750 mm ir $600 \mathrm{~mm}$ ) geležinkelių linijų. Tačiau labai trūko geležinkeliams skirtos technikos, ją reikèjo nuomotis, sukomplektuoti, pritaikyti įvairioms reikmėms arba pirkti.

Pagaliau 1920 m. sausio 18 d. geležinkelio dirbtuvèse Kaune pagal Rusijos kariuomenès šarvuotųjų traukinių pavyzdžius buvo pradėtas gaminti pirmasis Lietuvos kariuomenès šarvuotasis traukinys. Jị kuriant daugiausia dirbo inžinieriai ir konstruktoriai mjr. Leonas Šilingas, Georgijus Koršas, Jurgis Čiurlys, Vilius (Vilhelmas) Vaišvila, meistrai Fiše- 


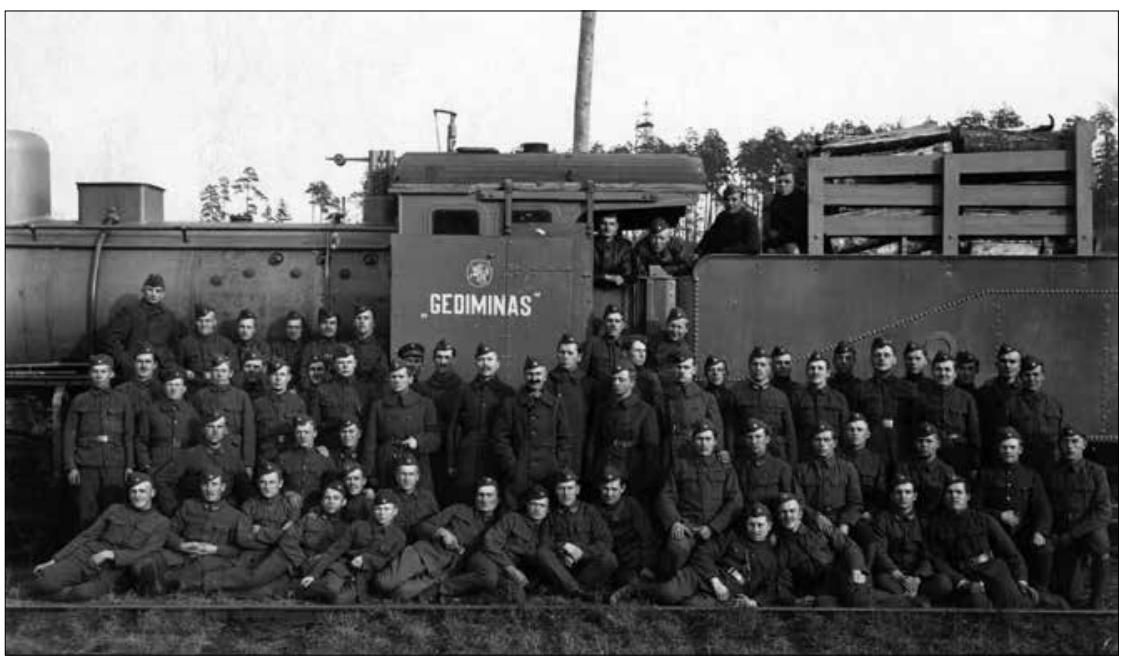

Šarvuotojo traukinio „Gediminas“ igula prie garvežio. 1920-1921 m.

Trečioje eilèje iš kairès stovi: 9-as - artilerijos platformos vadas ltn. Juozas Toliušis, 11-as - kulkosvaidžių vagono vadas ltn. Alfonsas Vilèniškis, 12-as - adutantas ltn. Kazys Pašys, 13-as - traukinio vado pareigas ejjęs plk. Itn. J. Kraucevičius, 14-as - traukinio vado pavaduotojas kpt. Petras Gudelis, 15-as - mechanikas ltn. Aleksandras Barota, 17-as - artilerijos platformos vadas ltn. Antanas Sidabras, 18-as - raštvedys karo valdininkas Mikas Cicènas

VDKM nuotrauku rinkiniai, Fa-13438

ris $^{11}$, Normantas ${ }^{12}$ ir darbininkai ${ }^{13}$. Rugpjūčio $25 \mathrm{~d}$. traukinys buvo parengtas ir pavadintas „Gediminu“14. Šj pavadinimą jam suteikè krašto apsaugos ministras, èjęs vyriausiojo kariuomenès vado pareigas, plk. ltn. Konstantinas Žukas ${ }^{15}$.

11 Straipsnio autoriui nežinomas minèto geležinkelio meistro vardas.

12 Straipsnio autoriui nežinomas minèto geležinkelio meistro vardas.

131934 m. J. Kraucevičiaus atsiminimai apie 1920-1924 m. Šarvuočių rinktinę, Lietuvos nacionalinès Martyno Mažvydo bibliotekos Retų knygu ir rankraščiu skyriaus (toliau LNMMB RKRS) Z. Ivinskio kolekcija, f. 29-730, 1. 20; V. Lesčius, Lietuvos kariuomenè 1918-1920, Vilnius, 1998, p. 142.

1419200118 Lietuvos Respublikos krašto apsaugos ministro ir vyriausiojo kariuomenès vado padejejo krn. A. Merkio įsakymas mjr. R. Tornberiui (R. W. Thornberry), Lietuvos centrinis valstybes archyvas (toliau - LCVA), f. 828, ap. 1, b. 113a, 1. 30.

151934 m. J. Kraucevičiaus atsiminimai apie 1920-1924 m. Šarvuočių rinktinę, LNMMB RK RSK, f. 29-730, 1. 5. 


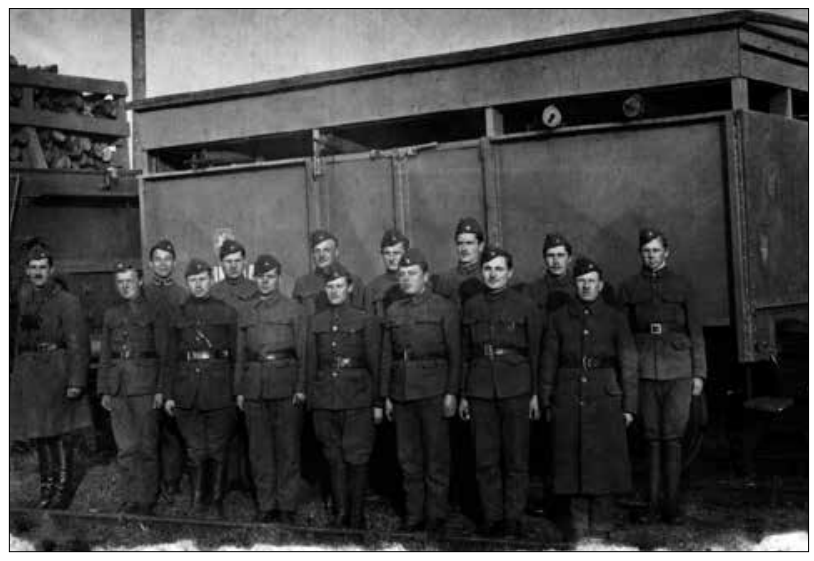

Šarvuotojo traukinio „Gediminas“ kulkosvaidžių vagono komanda prie vagono, ginkluoto $7,92 \mathrm{~mm}$ kalibro $1908 \mathrm{~m}$. modelio „Maxim $08^{“}$ (Vokietija) kulkosvaidžiais. Apie $1921 \mathrm{~m}$. Iš kairès pirmas kulkosvaidžių vagono vadas ltn. A. Vilèniškis VDKM nuotrauku rinkiniai, $\mathrm{Fa}-14934 / 12$

Pirmosiomis dienomis, kai buvo sukomplektuotas šarvuotasis traukinys, pradèta komplektuoti nuolatinè vadovaujančio personalo kadrinė sudètis. Eiti šarvuotojo traukinio "Gediminas“ vado pareigas buvo patikèta šarvuotosios karo technikos specialistui krn. Jonui Kraucevičiui ${ }^{16}$, kuris tapo pavaldus Generalinio štabo viršininkui. Tą pačią dieną eiti jo adjutanto pareigas buvo paskirtas ltn. Kazys Pašys ${ }^{17}$. Traukinio vado padejeju tapo kpt. Juozas Giedraitis, kuris ejjo ir ūkio vedejo pareigas ${ }^{18}$, vèliau ji pakeitè kpt. Petras Gudelis ${ }^{19}$. Traukinio raštinei vadovauti buvo paskirtas karo valdininkas Mikas Cicènas ${ }^{20}$, artilerijos platformų vadu vyr. ltn. Juozas Rymeikis ${ }^{21}$, ejjęs ir iždininko pareigas. Tačiau netrukus kai

16 Lietuvos kariuomenei ịsakymas Nr. 422/7, Kaunas, 1920 m. rugsèjo 2 d.; Šarvuotam traukiniui „Gediminas“ issakymas Nr. 1/1, Kaunas, 1920 m. rugpjūčio 25 d., LCVA, f. 828, ap. 1, b. $5,1.1$.

17 Šarvuotam traukiniui „Gediminas“ isakymas Nr. 1/3, Kaunas, 1920 m. rugpjūčio 25 d., ten pat, b. $4,1.1$.

18 Šarvuotam traukiniui „Gediminas“ itsakymas Nr. 9/3, Kaunas, 1920 m. rugsèjo 9 d., ten pat, 1. 10 ap; Šarvuotam traukiniui „Gediminas“ ìsakymas Nr. 30/2, Kaunas, 1920 m. spalio 5 d., ten pat, 1. 34 ap.

19 Šarvuotam traukiniui „Gediminas“ isakymas Nr. 30/7, Kaunas, 1920 m. spalio 5 d., ten pat, 1. 35 .

20 Šarvuotam traukiniui „Gediminas“ įsakymas Nr. 3/2, Kaunas, 1920 m. rugsejjo 1 d., ten pat, 1. 1 ap.

21 Šarvuotam traukiniui „Gediminas“ įsakymas Nr. 2/1, Kaunas, 1920 m. rugpjūčio 26 d., ten pat, 1. 1; Šarvuotam traukiniui „Gediminas“ isakymas Nr. 9/2, Kaunas, 1920 m. 
kurių traukinio karininkų, atšauktų iš pareigų ir paskirtų i kitus dalinius, tarnybos vietas užėmè perspektyvūs jaunesnieji karininkai. Leitenantai Antanas Sidabras ir Juozas Toliušis buvo paskirti artilerijos platformos vadais $^{22}$, Alfonsas Vilëniškis - kulkosvaidžių vagono vadu ${ }^{23}$, traukinio mechaniku - ankstesnès tarnybos patirties šarvuotajame traukinyje turintis ltn. Aleksandras Barota ${ }^{24}$, o traukinio kareivių komandos viršila kareivis Petras Visockis ${ }^{25}$.

1920 m. rugsèjo $1 \mathrm{~d}$. šarvuotojo traukinio „Gediminas“ personalą sudare 7 karininkai, 1 karo valdininkas ir $62^{26}$ (metų pabaigoje - 76) rikiuotès ir ne rikiuotès kareiviai, skirti ị nuolatinę tarnybą iš artilerijos ir pèstininkų pulkų, Elektrotechnikos ir Atskirojo geležinkelių batalionų, naujokai iš etapo skirstymo punkto ${ }^{27}$. Nors pagal etatinę sudètị traukinyje turejjo būti per 100 karių, iš tikrųjų jų buvo mažiau ir viena pamaina, nors reikejo mažiausiai dviejų ${ }^{28}$.

Tuo metu ịvairiose kariuomenès dalyse trūko karių specialistų, todèl formuojant šarvuotajj̨ traukinį dalyvavo ir laikinai prie jo priskirti kitų karinių dalinių kariai arba net jų padaliniai. Pvz., 1920 m. rugsejjo 22-spalio $2(10)^{29} \mathrm{~d}$. prie šarvuotojo traukinio buvo priskirta laisvai samdomų geležinkelininkų brigada iš geležinkelio bataliono, kurią sudarẻ 3 kareiviai: mašinistas Adolfas Venskevičius, mašinisto padejjejas Kazys Bražiūnas ir

rugsèjo 9 d., ten pat, 1. 10 ap; Šarvuotam traukiniui „Gediminas“ isakymas Nr. 30/3, Kaunas, $1920 \mathrm{~m}$. spalio 5 d., ten pat, l. 34 ap.

22 Šarvuotam traukiniui „Gediminas“ isakymas Nr. 8/6, Kaunas, 1920 m. rugsejjo 7 d., ten pat, 1. 10; Šarvuotam traukiniui „Gediminas“ isakymas Nr. 30/5, Kaunas, 1920 m. spalio 5 d., ten pat, 1. 35.

23 Šarvuotam traukiniui „Gediminas“ issakymas Nr. 13/3, Kaunas, 1920 m. rugsejjo 14 d., ten pat, 1. 15.

24 Šarvuotam traukiniui „Gediminas“ issakymas Nr. 25/4, Kaunas, 1920 m. rugsèjo 29 d., ten pat, 1. 26.

25 Šarvuotam traukiniui „Gediminas“ issakymas Nr. 11/2, Kaunas, 1920 m. rugsejjo 11 d., ten pat, l. 14.

26 V. Lesčius, Lietuvos kariuomene 1918-1920, p. 408.

27 Ten pat, p. 412.

281920 m. spalio mėn. Lietuvos Respublikos KAM šarvuotojo traukinio „Gediminas“ vado adjutanto ltn. K. Pašio pranešimas Artilerijos skyriaus viršininkui, LCVA, f. 828, ap. 1, b. 7, 1. 7 .

29 Kitais duomenimis, 1920 m. spalio $10 \mathrm{~d}$. 
kūrikas Otonas Gessas (Ottonas Hessas) ${ }^{30}$.

Pagal patvirtintus etatus, šarvuotajam traukiniui vadovavo karininkas - pulkininkas leitenantas. Jam buvo pavaldūs karininkai: traukinio vado padejjejas-ūkio vedẻjas, adjutantas, mechanikas, sprogdintojas, raštvedys (karininkas arba karo valdininkas), taip pat artilerijos platformos ir kulkosvaidžio vagono vadai, jaunesnieji karininkai - nuo leitenanto iki vyr. leitenanto. Traukinio kareivių komandai ir puskarininkiams vadovavo viršila. Komandą sudarè: artileristai (po 8 prie kiekvieno pabūklo) ir kulkosvaidininkai (po 2 prie kiekvieno kulkosvaidžio), sprogdintojai, telefonistai, sekèjai, garvežio mašinistas, jo padejjèjas, kūrikas, geležinkelininkai, raštininkai, šaltkalvis, dailidè, kalviai, iešmininkai, virëjai, ūkvedys, artelininkas, pasiuntinys, batsiuvys, siuvejas ir vyr. gydytojo padejejejas $^{31}$.

Karo metu Lietuvos kariuomenès šarvuotajj traukinị sudare dvi pagrindinès dalys - kovinè ir bazinè. Kovinę dali - garvežys, 1-3 artilerijos platformos (vadintos lèkštvagoniais), ginkluotos patrankomis ir haubicomis, 1-2 kulkosvaidžių vagonai, kurių kiekviename paprastai būdavo 4-6 kulkosvaidžiai. Bazinę dalị sudarẻ keliolika rusiško ir vokiško tipo keleivinių vagonų dalinio komandai gyventi (I ir II klasės karininkų, III klasès kareivių patalpos, prausykla), mokytis (klasès), dirbti (štabas, raštinè, sargybos būstas), maistui gaminti ir valgyti (virtuvè ir valgykla), ilsètis, bendrauti ir spręsti aktualius reikalus (ramovè), gydytis (ambulatorija), ịvairios paskirties prekinių vagonų sandèliams ir dirbtuvems, kontrolinès platformos su geležinkelio reikmenimis (bẻgiais, ̨̧rankiais) ir pagalbinemis priemonemis ${ }^{32}$. Bazinis sąstatas buvo bendras visam traukiniui arba daliniui ${ }^{33}$, jis buvo naudojamas apsaugai ir paramai teikti ${ }^{34}$.

\footnotetext{
30 Šarvuotam traukiniui „Gediminas“ itsakymas Nr. 21/2, Kaunas, 1920 m. rugsejjo 24 d., ten pat, b. 5, 1. 19 ap; Šarvuotam traukiniui „Gediminas“ isakymas Nr. 27/2, Kaunas, 1920 m. spalio 1 d., ten pat, 1. 31 ap; Šarvuotam traukiniui „Gediminas“ isakymas Nr. 34/3, Kaunas, 1920 m. spalio 9 d., ten pat, 1. 40.

31 Šarvuotam traukiniui „Gediminas“ issakymo Nr. 28/2 priedas, Kaunas, 1920 m. spalio 2 d., ten pat, b. 4, 1. 32 ap-33 ap.

32 Instrukcija šarvuotiems traukiniams, Kaunas, [1922], d. I, p. 3, 30.

33 1920-1922 m. Lietuvos Respublikos KAM šarvuotųjų traukinių pulko istorinè apžvalga, $L C V A$, f. 828 , ap. 1, b. 8, 1. 21 ap.

34 [J.] Kraucevičius, Plienu gaubta kariuomenè, Karys, 1924, Nr. 44, p. 360.
} 


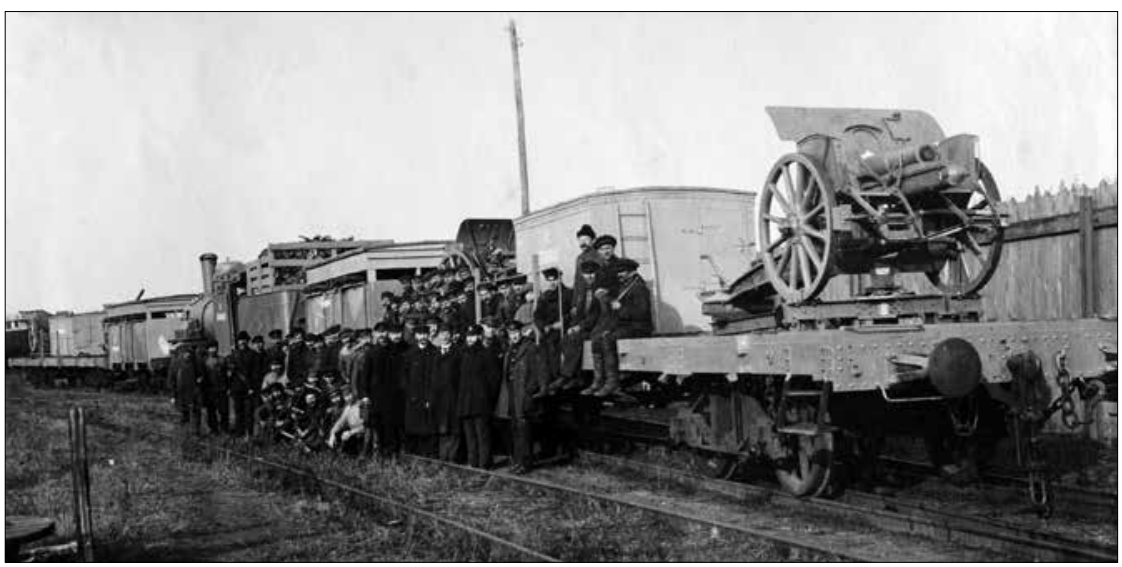

Kauno geležinkelio dirbtuvių tarnautojai ir darbininkai, parengę šarvuotąjị traukinị „Gediminas“, prie traukinio kovinès dalies. Apie $1921 \mathrm{~m}$.

VDKM nuotrauku rinkiniai, Fa-14934/21

Šarvuotasis traukinys „Gediminas“ buvo komplektuojamas ir laikomas Kauno geležinkelio stoties komplekse, kur buvo tinkamos funkcinès zonos ir infrastruktūros objektai. Nuo 1920 m. spalio $10 \mathrm{~d}$. iki lapkričio $12(20)^{35} \mathrm{~d}$. geležinkelio dirbtuvèse buvo šarvuojama ir ginkluojama traukinio kovinè ir remontuojama bazinè dalis ${ }^{36}$; nuo lapkričio $25 \mathrm{~d}$. iki 1921 m. rugpjūčio 1 d. „Gediminas“ stovejjo ant atsarginių bėgių Kauno geležinkelio stotyje, prie siaurojo geležinkelio dirbtuvių, kuriose toliau buvo rengiamos ir šarvuojamos 2 artilerijos platformos, 2 kulkosvaidžių vagonai, buvo įrengti prekiniai vagonai, padidintas vagonų ir platformų skaičius $^{37}$. Vèliau traukinys stovejo XIX a. pab. Kauno tvirtovès statytojų įrengtoje trijų bėgių kelių karinejje geležinkelio stotyje, t. y. prie siauro-

\footnotetext{
35 Kitais duomenimis, $1920 \mathrm{~m}$. lapkričio $20 \mathrm{~d}$.

36 Generalinio štabo Technikos skyriui ísakymas Nr. 8/1, Kaunas, 1920 m. lapkričio 24 d., LCVA, f. 929, ap. 9, b. 25, 1. 11; 1920-1922 m. Lietuvos Respublikos KAM šarvuotųjų traukinių pulko istorinè apžvalga, ten pat, f. 828, ap. 1, b. 8, 1. 15 ap.

37 1920-1922 m. Lietuvos Respublikos KAM šarvuotųjų traukinių pulko istorinė apžvalga, ten pat, 1. 19-20; 1933 m. spalio mèn. Lietuvos Respublikos KAM šarvuotụjų traukinių pulko mechaniko vyr. ltn. A. Barotos raštas Geležinkelių valdybos Traukos tarnybos viršininkui, ten pat, b. 23, 1. 57.
} 


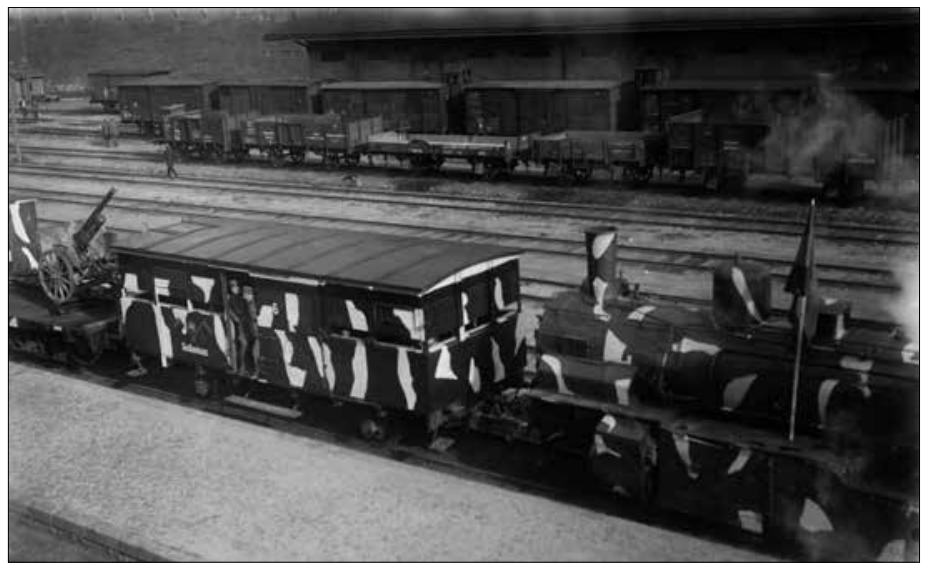

Šarvuotasis traukinys "Gediminas“ Kauno geležinkelio stotyje. $1920 \mathrm{~m}$.

VDKM nuotrauky rinkiniai, Fa-15993

jo geležinkelio dirbtuvių Žemutinèje Fredoje ${ }^{38}$, kuri jungèsi su plačiuoju geležinkeliu ${ }^{39}$.

Iš pradžių šarvuotasis traukinys „Gediminas“ buvo nudažytas prancūziško, vèliau - vokiško tipo kamufliažu, t. y. slepiamąja spalva su netaisyklingų formų dèmèmis arba tik slepiamąja spalva, o atskiroms užduotims vykdyti buvo maskuojamas medžiais ir šakomis ${ }^{40}$. Ant traukinio garvežio ir vagonų šonų buvo pavaizduotas baltas Vytis raudoname fone, baltos spalvos dažais parašytas traukinio pavadinimas ir vagonų numeriai. Traukinio karininkai buvo ginkluoti 7,65 mm „Mauser“ (Vokietija), „Browning“ (Belgija) ir „Retolaza“ (Ispanija) pistoletais, kardais, puskarininkiai - 9 mm „Parabellum“ (Vokietija) pistoletais, kareiviai - 7,92 mm $1888 \mathrm{~m}$. modelio lengvaisiais pėstininkų šaunamaisiais ginklais, $1898 \mathrm{~m}$. modelio „Mauser“ (Vokietija) šautuvais ir karabinais, granatomis ${ }^{41}$. Iš

38 [J.] Budzilas, Šarvuočių rinktinè, Mūsų žinynas, 1928, t. 15, Nr. 45, p. 346; V. Statkus, Lietuvos ginkluotos pajegos 1918-1940 m., Chicago, 1986, p. 348.

39 V. Orlov, Kauno tvirtoves istorija, Kaunas, 2007, p. 120-121; A. Pociūnas, Kauno tvirtovés gynyba 1915 metais, Kaunas, 2008, p. 58.

40 А. В. Шавровъ, Бронепоздюзда. Значеніе, вооруженіе, организація и тактика бронепоздпздовъ, Бълградъ, 1927, с. 19.

4119200908 Lietuvos Respublikos KAM šarvuotojo traukinio „Gediminas“ ginklų, ịvairių įrankių ir kito turto statistinès žinios, $L C V A$, f. 929, ap. 4, b. 131, 1. 1 ap; Šarvuotam traukiniui „Gediminas“ issakymas Nr. 36/4, Kaunas, 1920 m. spalio 12 d., ten pat, f. 828, ap. 1, b. $5,1.56$. 
pradžių kariai daugiausia dèvèjo amerikietiškas karines uniformas su lietuviškais skiriamaisiais ženklais, o tarnybos ir darbo metu, be to, odinius ir darbo kostiumus.

1920 m. šarvuotojo traukinio „Gediminas“ kovinę dalị sudarẻ garvežys, artilerijos platformos ir kulkosvaidžių vagonai, gauti iš Geležinkelių valdybos ir kartu su ginkluote sukomplektuoti Kauno geležinkelio ir artilerijos dirbtuvèse ${ }^{42}$. Vienu metu traukini sudare 1-3 artilerijos platformos, ginkluotos 4-6 $75 \mathrm{~mm} 1916 \mathrm{~m}$. (Prancūzija), $77 \mathrm{~mm} 1914$ ir 1916 m. modelio lauko patrankomis ir $2105 \mathrm{~mm} \mathrm{1898/1909} \mathrm{m.} \mathrm{modelio}$ „Kruppo“ lauko haubicomis (Vokietija); ant vienos iš jų buvo pastatyta keturkampé šarvuota vadavietė, kurios galuose buvo įrengtos durys su pabūklų tarnybomis susisiekti, lubose padaryta anga, pro kurią viduje įrengtomis kopéčiomis buvo galima patekti ị sekyklą, o šonuose ịtaisyti 4 kulkosvaidžiai. Šarvuotieji vagonai buvo ginkluoti 4-16 7,92 mm 1908 m. modelio „Maxim 08“ (Vokietija) kulkosvaidžių ${ }^{43}$.

Vienas svarbiausių šarvuotojo traukinio komponentų buvo šarvai, kurie traukinio formavimo pradžioje buvo gauti iš Kauno geležinkelio dirbtuvių, o metalas rekvizuotas iš Brolių Šmidtų (Schmidt) ir Nikola-

42 O. Žadvydas, Šarvuočių rinktinè, Karys, 1970, Nr. 7, p. 205; A. Pociūnas, Buvo pasiruošę ginti Lietuvą... Šarvuoti traukiniai ir tankai, Tëviškès žinios, 1989 m. gruodžio 5 d., Nr. 145, p. 3; Šarvuotam traukiniui „Gediminas“ i̇sakymas Nr. 27a/1, Kaunas, 1920 m. spalio 1 d., $L C V A$, f. 828, ap. 1, b. 4, 1. 31; Šarvuotam traukiniui „Gediminas“ isakymas Nr. 56/14, Kaunas, 1920 m. lapkričio 18 d., ten pat, 1. 67.

43 Šarvuotam traukiniui „Gediminas“ ịsakymas Nr. 21/8, Kaunas, 1920 m. rugsejjo 24 d., LCVA, f. 828, ap. 1, b. 5, 1. 31ap; 19201021 Lietuvos Respublikos KAM šarvuoto traukinio „Gediminas" vado plk. ltn. J. Kraucevičiaus pranešimas Generalinio štabo viršininkui, ten pat, b. 7, 1. 5; 19200908 Lietuvos Respublikos KAM šarvuotojo traukinio „Gediminas“ ginklų, įvairių įrankių ir kito turto statistinès žinios, ten pat, f. 929, ap. 4, b. 131, 1. 1; 19200922 Lietuvos Respublikos KAM šarvuotojo traukinio „Gediminas“ ginklų, ịvairių ịrankių ir kito turto statistinès žinios, ten pat, 1. 3-3 ap; 19201001 Lietuvos Respublikos KAM šarvuotojo traukinio „Gediminas“ ginklų, įvairių įrankių ir kito turto statistinès žinios, ten pat, 1. 4-4 ap; 19201022 Lietuvos Respublikos KAM šarvuotojo traukinio „Gediminas“ ginklų, ịvairių ịrankių ir kito turto statistinès žinios, ten pat, 1. 7; 19201122 Lietuvos Respublikos KAM šarvuotojo traukinio „Gediminas“ ginklų, ịvairių įrankių ir kito turto statistinès žinios, ten pat, 1. 12; 19201222 Lietuvos Respublikos KAM šarvuotojo traukinio „Gediminas“ ginklų, ịvairių įrankių ir kito turto statistinès žinios, ten pat, 1. 17; Šarvuotam traukiniui „Gediminas“ isakymas Nr. 21/8, Kaunas, 1920 m. rugsèjo 24 d., ten pat, f. 828, ap. 1, b. 5, 1. 31ap. 
jaus Rekošo dirbtuvių, atgabentas iš Kauno tvirtovės fortų ${ }^{44}$. Šarvais buvo apsaugota tik traukinio kovinè dalis, o bazinè taip ir liko nešarvuota. Šarvuoti buvo garvežio ratai, mašinisto kabina ir kitos svarbesnès dalys, artilerijos platformos - nešarvuotos, išskyrus jų šonus, kur buvo ịrengti geležiniai bortai ir šarvuotos keturkampès vadavietès; jų šarvų storis siekè 15-20 mm, tik vèliau atskirai patrankos buvo pridengtos $16 \mathrm{~mm}$ storio skydais. Kulkosvaidžių vagonų sienelių 20-30 mm tarpai buvo užpildyti $4 \mathrm{~mm}$ storio geležiniais lakštais ir smèliu.

Techniškai šarvuotojo traukinio kovinè dalis buvo silpna, iš dalies šarvuota ir ginkluota ịvairaus modelio ir kalibro pabūklais be specialiu stovų, išskyrus vieną patranką, iš kurios buvo galima šaudyti bet kuria kryptimi, kaip ir iš pabūklų, kurie buvo pritaikyti šaudyti ị visas puses ${ }^{45}$. Patrankos buvo primityviai ir nejudamai pritvirtintos, prastai buvo įrengti ir kulkosvaidžių vagonai. Juose kulkosvaidžiai buvo statomi tiesiog ant stovų, ir tai turèjo įtakos šaudymo kokybei. Bazinę dalị sudarantys keleiviniai ir prekiniai vagonai buvo seni ${ }^{46}$.

\subsection{Kovos su lenkais}

1920 m. rugsejjo 10 d. dar nevisiškai sukomplektuoto šarvuotojo traukinio „Gediminas“ igula gavo pirmąji kovinị ịsakymą vykti ị Suvalkų frontą. Čia ji dalyvavo Augustavo-Suvalkų karinèje operacijoje - kovose su lenkais. Traukinio, kurị sudarè garvežys, 3 artilerijos platformos, ginkluotos 6 patrankomis, 2 kulkosvaidžių vagonai, ginkluoti 16 kulkosvaidžių, 2 paprastos platformos, 2 III klasès vagonai ir 11 prekinių vagonų. Jo igula, kurią sudarè menkai su traukinio techninėmis ir taktinėmis savybėmis susipažinę karininkai ir prastai apmokyti kareiviai, turejjo žvalgyti geležinkelio ruožą Suvalkų kryptimi. Tačiau, dar vykstant ị Varèną, jau Kaišiadorių stotyje, aptikus šarvuotojo traukinio garvežio gedimą, buvo iškviestas paprastas garvežys. Jị pasitelkus, tik kitą dieną pavyko pasiekti Varènos stotị. Ten, išžvalgius vietovę, prasidejjo mokomieji šaudymai. Rugsẻjo 13-17 d. vyko šaudymo iš kulkosvaidžių

\footnotetext{
44 A. Pociūnas, Šarvuoti traukiniai Lietuvos kariuomeneje, Karys, p. 21.

45 [J.] Kraucevičius, Plienu gaubta kariuomene, Karys, p. 359.

46 [J.] Budzilas, Šarvuočių rinktinè, Mūsų žinynas, p. 346.
} 


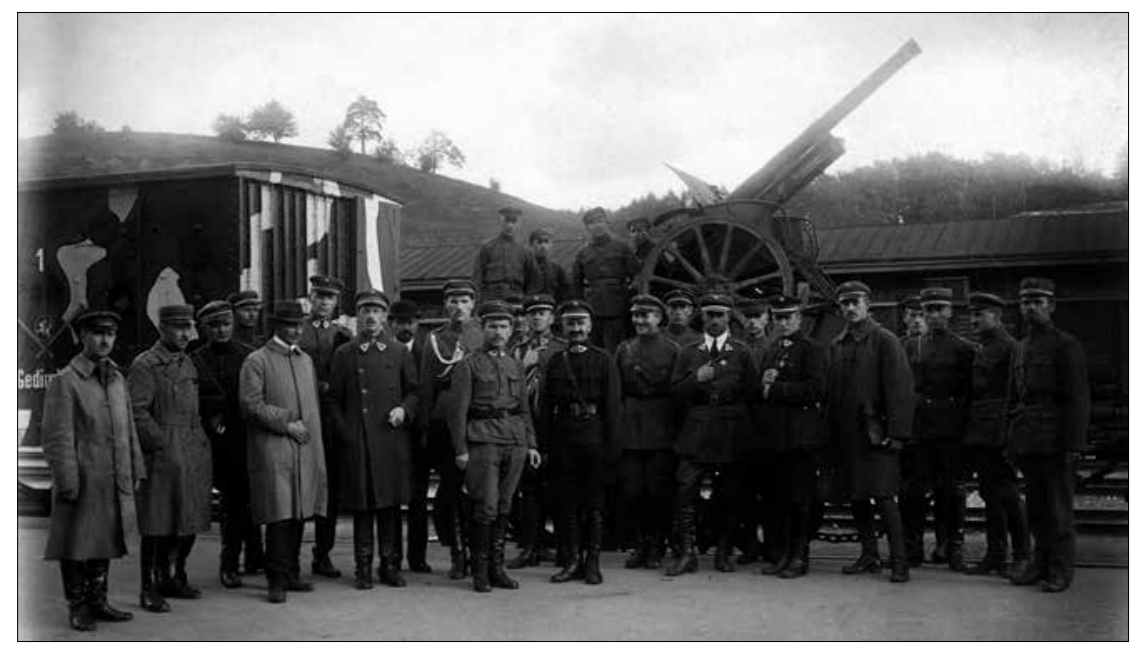

Šarvuotojo traukinio „Gediminas“ perèmimas iš geležinkelio dirbtuvių. Kaunas, 1920 m.

Iš kairès: 2-as - artilerijos pulko vadas plk. Itn. Mikas Gedgaudas, 3-ias - traukinio vado padejejjas kpt. Juozas Giedraitis, 4-as - artilerijos platformos vadas vyr. ltn. Juozas Rymeikis, 6-as - mjr. Lietuvos geležinkelių karinis viršininkas Adolfas Birontas, 7-as - ejęs Generalinio štabo Technikos skyriaus viršininko pareigas mjr. Leonas Šilingas, 8-as - Geležinkelių dirbtuvių viršininkas inž. Jurgis Čiurlys, 11 -as - krašto apsaugos ministras, ejęs vyriausiojo kariuomenès vado pareigas, plk. Itn. Konstantinas Žukas, 13-as - èjęs Generalinio štabo viršininko pareigas plk. Konstantinas Kleščinskis, 14-as - èjęs šarvuotojo traukinio „Gediminas“ vado pareigas plk. ltn. Jonas Kraucevičius, 15-as - traukinio vado adjutantas ltn. Kazys Pašys, 16-as - traukinio artilerijos platformos vadas ltn. Antanas Sidabras, 18-as - traukinio raštvedys karo valdininkas Mikas Cicènas, 19 -as - armijos vadas plk. ltn. Kazys Ladyga, 24-as - Kauno stoties komendantas kpt. Stanislovas Kuizinas Lietuvos centrinio valstybès archyvo Fotodokumentu skyrius (toliau - LCVA Fs), P-19416

ir pabūklų pratybos, jų metu tik iš vienos $77 \mathrm{~mm}$ patrankos buvo galima šaudyti visomis kryptimis, nes visos kitos buvo nejudamai pritvirtintos prie platformos. Rugsėjo 18-19 d. traukinys, grąžinus suremontuotą garveži, tęsè kelionę Alytaus kryptimi, o igulai gavus tolesnius nurodymus, rugsèjo $20 \mathrm{~d}$. atvyko ị Šeštokų stotị. Taigi rugsèjo 10-21 d. šarvuotojo traukinio „Gediminas“ igula atliko žvalgybą geležinkelio ruože Kaunas-Suvalkai ${ }^{47}$.

Kovos krikštą traukinys „Gediminas“ gavo rugsėjo 22 d. už Punsko, kur prie Seivų ežero ir Smalènų apšaudè lenkų artilerijos pozicijas ir grịžo ị Šeštokus, nes ten buvo likusi traukinio bazè. Kitą dieną traukinio

47 1920-1922 m. Lietuvos Respublikos KAM šarvuotụjų traukinių pulko istorinè apžvalga, $L C V A$, f. 828 , ap. 1, b. 8, 1.2-3 ap. 
igula tęsè savo veiksmus iki kryžkelès Vaitiekūnai-Punskas, apšaudè Rudavkos kaimą ir Smalènus, taip pat netoli buvusią priešininkų artilerijos bateriją, išardè nedideli geležinkelio ruožą, kad lenkai negalètų juo naudotis. Šias dvi dienas traukinio igula veikè kartu su 3-iuoju pėstininku Lietuvos didžiojo kunigaikščio Vytauto pulko padaliniu ir 6-ojo pėstininkų Pilènų kunigaikščio Margio pulko 6-ąja kuopa. Rugsèjo 23 d. vakare traukinio kovinè dalis grižo ị Šeštokus. I pozicijas traukinys išvyko ir kitą dieną, bet netrukus igula gavo įsakymą vèl grižzi ị Varẻną, kur padalinys buvo priskirtas prie 7-ojo pestininkų Žemaičių kunigaikščio Butigeidžio pulko. Rugsèjo 25 d. „Gedimino“ kariai gavo įsakymą išžvalgyti kelio ruožą Gardino link, bet traukinys sustojo prie tilto per Ūlos upę, kurị lenkai buvo susprogdinę. Jị kartu su vietos gyventojais sutaisius, atvyko ị Marcinkonis. Prie Marcinkonių susidūrè su stipriomis lenkų pajègomis. Jị apšaudè priešo pèstininkai ir artilerija (iš 4 pabūklų). Kautynių metu pastebètą pro traukinị žygiuojančią lenkų gurguolę po kovos traukinys išblaškè, tačiau buvo priverstas atsitraukti ir grịžo ị Varẻną. Už pasižymejjimą prie Marcinkonių trys traukinio kareiviai buvo pakelti i jaunesniuosius puskarininkius, keturi - i grandinius. Rugsejjo 26-29 d. buvo pakartotinai atliekama žvalgyba Marcinkonių link, jos metu paaiškejjo, kad geležinkelio tiltas per Ülos upę vèl susprogdintas. Traukinio vadovybẻ buvo net išsiuntusi ltn. K. Pašio vadovaujamą žvalgų grupę, bet ji priešo nepastebejjusi grịžo ị Varèną ${ }^{48}$.

Rugsėjo 29 d. lenkai ėmė pulti Varènos link, užėmė Mergežerio ir Zervynos kaimus prie Ūlos. Tik rugsèjo $30 \mathrm{~d}$. buvo gautas ịsakymas padèti 1-ajam pèstininkų Lietuvos didžiojo kunigaikščio Gedimino pulkui iš šių kaimų išstumti lenkus ${ }^{49}$. Traukinys, atlikus žvalgybą ir gavus pastiprinimą - vieną pèstininkų būrị, paleido ugnị. Lenkai buvo išstumti. Šių veiksmų metu užimtas Zervynos kaimas, kuriame buvo ịsitvirtinusios 1-2 lenkų 205-ojo pėstininkų pulko kuopos, paimta keletas belaisvių ir nukauta 10 priešo karių, tačiau dèl karių trūkumo besitraukiančio priešo nebandyta persekioti, todèl traukinys buvo priverstas atsitraukti ir persigrupuoti. Šių veiksmų metu iš jo dar kartą buvo apšaudyti ir išsklaidyti lenkai ${ }^{50}$.

\footnotetext{
48 Ten pat, 1. 4 ap-6 ap; V. Lesčius, Lietuvos kariuomene 1918-1920, p. 409.

49 Ten pat.

50 1920-1922 m. Lietuvos Respublikos KAM šarvuotųjų traukinių pulko istorinè apžvalga, LCVA, f. 828 , ap. 1, b. 8, 1. 7-8 ap.
} 
Spalio 2 d. lenkai vèl užèmė Zervynos kaimą, bet, pamatę artëjantị šarvuotajji traukinị su péstininkais žvalgais, pasitrauké $\dot{j}^{51}$. Netrukus kilo grèsmè, kad jie gali atkirsti geležinkelị ir atsitraukimo kelius ị saugų užnugarị. Traukinio vadovybẻ paprašè leidimo važiuoti $\mathfrak{i}$ Valkininkus, kad ten atliktų žvalgybą. Tačiau leidimo visam sąstatui vykti negavo. Buvo pareikšta, kad dalis traukinio turi likti Varénoje pėstininkų moraliai palaikyti. I Valkininkus išvyko dvi artilerijos platformos, ginkluotos $75 \mathrm{~mm}$ patrankomis ir $105 \mathrm{~mm}$ haubicomis, ir bazè, vadovaujamos ltn. K. Pašio $^{52}$. Tačiau Varènoje po mūšio lietuviai pèstininkai atsitraukè. Traukiniui kilo grèsmè būti apsuptam, todèl likusi jo dalis buvo priversta trauktis Valkininkų link, bet už Varėnos jau laukẻ ant bėgių civilių geležinkelio tarnautojų užverstas rąstų prikrautas prekinis vagonas. Vykstant kovos veiksmams buvo pažeistas garvežys, todèl toliau judèti nebuvo galima. Traukinio vadas krn. J. Kraucevičius liepė ardyti patrankas ir kulkosvaidžius, kad ginkluotè neatitektų priešui, ir apleisti traukinị. Priedangai užtikrinti buvo palikta karių grupė, vadovaujama ltn. A. Vileniškio, su trimis kulkosvaidininkais, kurie buvo įsitvirtinę galiniame kulkosvaidžių vagone, nes traukinys buvo apšaudomas išilgai geležinkelio. Jie dar porą trejetą valandų neleido lenkams priartèti prie traukinio, vèliau, pasinaudoję prieblanda, sèkmingai pasitrauké $\dot{e}^{53}$.

Žuvo 2 traukinio komandos kulkosvaidininkai ir 3 kareiviai, buvo sužeisti 4 kariai $^{54}$. Kaip karo grobis lenkams atiteko garvežys Nr. 4202, artilerijos platforma, 2 kulkosvaidžių vagonai, 1 paprasta platforma su geležinkelio įrankiais, 16 kulkosvaidžių, apie 60 artilerijos sviedinių, 10 tūkst. šovinių, 7 šautuvai, 4 telefono aparatai, $5 \mathrm{~km}$ telefono kabelio ir

\footnotetext{
51 Ten pat, 1. 9-9 ap.

521934 m. J. Kraucevičiaus atsiminimai apie 1920-1924 m. Šarvuočių rinktinę, LNMMB $R K$ RSK, f. 29-730, 1. 13; 1920-1922 m. Lietuvos Respublikos KAM šarvuotųjų traukinių pulko istorinè apžvalga, $L C V A$, f. 828, ap. 1, b. 8, 1. 10-10 ap; V. Žeimantas, Pirmajam Lietuvos šarvuotam traukiniui „Gediminas“ - 90 metų, <http://www.mokslasirtechnika. lt/2011-nr.1/2011-nr.1.html> [žiūrèta: 201507 24].

53 1920-1922 m. Lietuvos Respublikos KAM šarvuotųjų traukinių pulko istorinė apžvalga, LCVA, f. 828, ap. 1, b. 8, 1. 11-12.

54 Z. Ivinskis, Šarvuočių rinktinės istorija: rinktinès 15-os metų sukakčiai pažymèti nuo 1920.VII.14 iki 1935.VII.14, LNMMB RK RSK, f. 29-700, 1. 41; 1934 m. K. Pašio atsiminimai apie šarvuočių rinktinę, $L N M M B R K R S K$, f. 29-732, 1. 10.
} 
daug kito turto ${ }^{55}$. Paimtus riedmenis lenkai panaudojo savo reikmėms ir pavadino naujai suformuotą šarvuotąji traukinị "Janu Kilinskiu“ (Jan Kiliński) ${ }^{56}$.

Spalio 4 d. ị Varènos geležinkelio stotị buvo pasiųsti 5-6 Lietuvos karo aviacijos LVG CVI ir „Albatros C III“ (Vokietija) lèktuvai prarastam traukinio sąstatui, kurị lenkai galejo panaudoti prieš lietuvių kariuomenę, sunaikinti. Tačiau to padaryti nepavyko - jis buvo tik apgadintas bombarduojant stoties rajoną. Traukinio sąstatą lenkai iš Varènos suspèjo išvežti ir paslèpti Vilniaus tunelyje ${ }^{57}$. Likusi šarvuotojo traukinio dalis su paprastu garvežiu buvo panaudota spalio $4 \mathrm{~d}$. ginant Valkininkus ir remiant péstininkus ${ }^{58}$, iš Valkininkų dislokuota j Rūdiškes, spalio 5-6 d. saugojo geležinkelio stotị nuo galimo priešo puolimo, spalio 6-7 d. Lentvaryje - tiltą per Vokès upę. Spalio $8 \mathrm{~d}$. buvo gautas ịsakymas vykti $\mathfrak{i}$ Vilnių saugoti geležinkelio ruožo Vilnius-Lyda ir apsistoti Kirtimų stotyje. Tą pačią dieną geležinkelių kuopos statybos būriui ịrengus kliūtį už Merkio upès geležinkelio tilto, nuo bėgių nuvažiavo iš Varènos į Valkininkus vykęs lenkų šarvuotasis traukinys su garvežiu ir dviem vagonais ${ }^{59}$. Tačiau vakare lietuvių traukinys iš Vilniaus išvyko atgal ị Lentvarị ir ten saugojo geležinkelio stotị. Spalio $9 \mathrm{~d}$. dalis traukinio dalyvavo lenkų apšaudyme, tačiau tą pačią dieną, vykdydama karinès vadovybės nurodymą, išvyko ị Vievị ir kitą dieną grịžo ị Kauną ${ }^{60}$.

Nuo spalio 10 iki lapkričio 20 d. Kauno geležinkelių dirbtuvèse buvo šarvuojama ir ginkluojama kovinè traukinio dalis - garvežiai, du kulkosvaidžių vagonai, viena artilerijos platforma, prancūziškos ir vokiškos

\footnotetext{
55 1920-1922 m. Lietuvos Respublikos KAM šarvuotųjų traukinių pulko istorinè apžvalga, $L C V A$, f. 828, ap. 1, b. 8, 1. 12 ap-13; Šarvuotam traukiniui „Gediminas“ ìsakymas Nr. 46a/3, Kaunas, 1920 m. spalio 30 d., ten pat, b. 4, 1. 51.

56 A. Pociūnas, Šarvuoti traukiniai Lietuvos kariuomeneje, Karys, p. 23.

57 J. Dovydaitis, Svaidom ugnị ir plieną, Lietuvos sparnai, 1938, Nr. 3, p. 83; G. Ramoška, Lietuvos karo aviacija Nepriklausomybès karuose, Plieno sparnai, 1994, Nr. 2, p. 6; V. Lesčius, Lietuvos kariuomene Nepriklausomybès kovose 1918-1920, Vilnius, 2004, p. 389.

58 O. Žadvydas, Šarvuočių rinktinè, Karys, 1970, Nr. 7, p. 206.

59 J. Baublys, Geležinkelių būrys Vilniaus kryptimi, Karys, 1961, Nr. 5, p. 139; O. Žadvydas, Šarvuočių rinktinè, Karys, 1970, Nr. 7, p. 208.

60 1920-1922 m. Lietuvos Respublikos KAM šarvuotųjų traukinių pulko istorinė apžvalga, LCVA, f. 828, ap. 1, b. 8, 1. 14-15.
} 
patrankos buvo pastatytos ant sukamųjų prietaisų, remontuojama ir pritaikoma tarnybai bazine dalis ${ }^{61}$.

Lapkričio $21 \mathrm{~d}$. traukinys išvyko ị Jonavą saugoti geležinkelio tilto nuo galimo lenkų kavalerijos brigados, kuri per frontą prie Giedraičių judèjo Kèdainių-Jonavos kryptimi, antpuolio. Tada traukini sudarè kovinè dalis (garvežys, dvi artilerijos platformos su 4 pabūklais ir du kulkosvaidžių vagonai su 10 kulkosvaidžių $\left.{ }^{62}\right)$ ir bazè, prie traukinio priskirtas pèstininkų skyrius ir viena Elektrotechnikos bataliono kuopa. Visi prie traukinio priskirti padaliniai buvo paskirstyti tam tikrų užduočiu vykdyti: vienas karių būrys buvo ant tilto, kitas - per $1 \mathrm{~km}$ nuo jo, dar kitas - rezerve. Traukinio igula atliko žvalgybą $15 \mathrm{~km}$ atstumu Šètos miestelio link. Vèliau traukinys kelis kartus vyko ị Kèdainius, nes $5 \mathrm{~km}$ nuo miesto buvo sugadintas geležinkelis, telefono ir telegrafo linijos. O dar vèliau jo kovine dalis buvo priskirta prie 1-ojo pasienio pulko ${ }^{63}$. Šarvuotasis traukinys "Gediminas“ iki lapkričio 24 d. veikè Kèdainiuose ir jo apylinkèse: Apytalaukyje, Ginaičiuose ir Pridotkuose apšaudè lenkų kavaleriją ir kitą dieną grižzo ị Kauną ${ }^{64}$. Nuo 1920 m. lapkričio 25 d. iki $1921 \mathrm{~m}$. rugpjūčio 1 d. „Gediminas“ stovejo ant atsarginių bėgių Kauno geležinkelio stotyje, prie geležinkelio dirbtuvių, kur toliau buvo įrengti ir pusiau apšarvuoti du garvežiai, dvi artilerijos platformos (ant pabūklų uždèti skydai, ịrengti amunicijos bokšteliai) ir du kulkosvaidžių vagonai, sutvarkyti prekiniai vagonai, skirti kariams gyventi, padidintas vagonų ir platformų skaičius ${ }^{65}$.

\footnotetext{
61 Ten pat, 1. 15 ap.

62 V. Lesčius, Lietuvos kariuomene 1918-1920, p. 411.

63 1920-1922 m. Lietuvos Respublikos KAM šarvuotųjų traukinių pulko istorinė apžvalga, $L C V A$, f. 828, ap. 1, b. 8, 1. 16-17.

64 V. Žeimantas, „Gediminas“ - pirmasis lietuvių šarvuotasis traukinys, Geležinkelininkas, 2000 m. rugpjūčio 1-15 d., Nr. 15, p. 4.

65 1920-1922 m. Lietuvos Respublikos KAM šarvuotųjų traukinių pulko istorinè apžvalga, LCVA, f. 828, ap. 1, b. 8, 1. 19-20; 1933 m. spalio mèn. Lietuvos Respublikos KAM šarvuotųjų traukinių pulko mechaniko vyr. ltn. A. Barotos raštas Geležinkelių valdybos Traukos tarnybos viršininkui, ten pat, b. 23, 1. 57.
} 


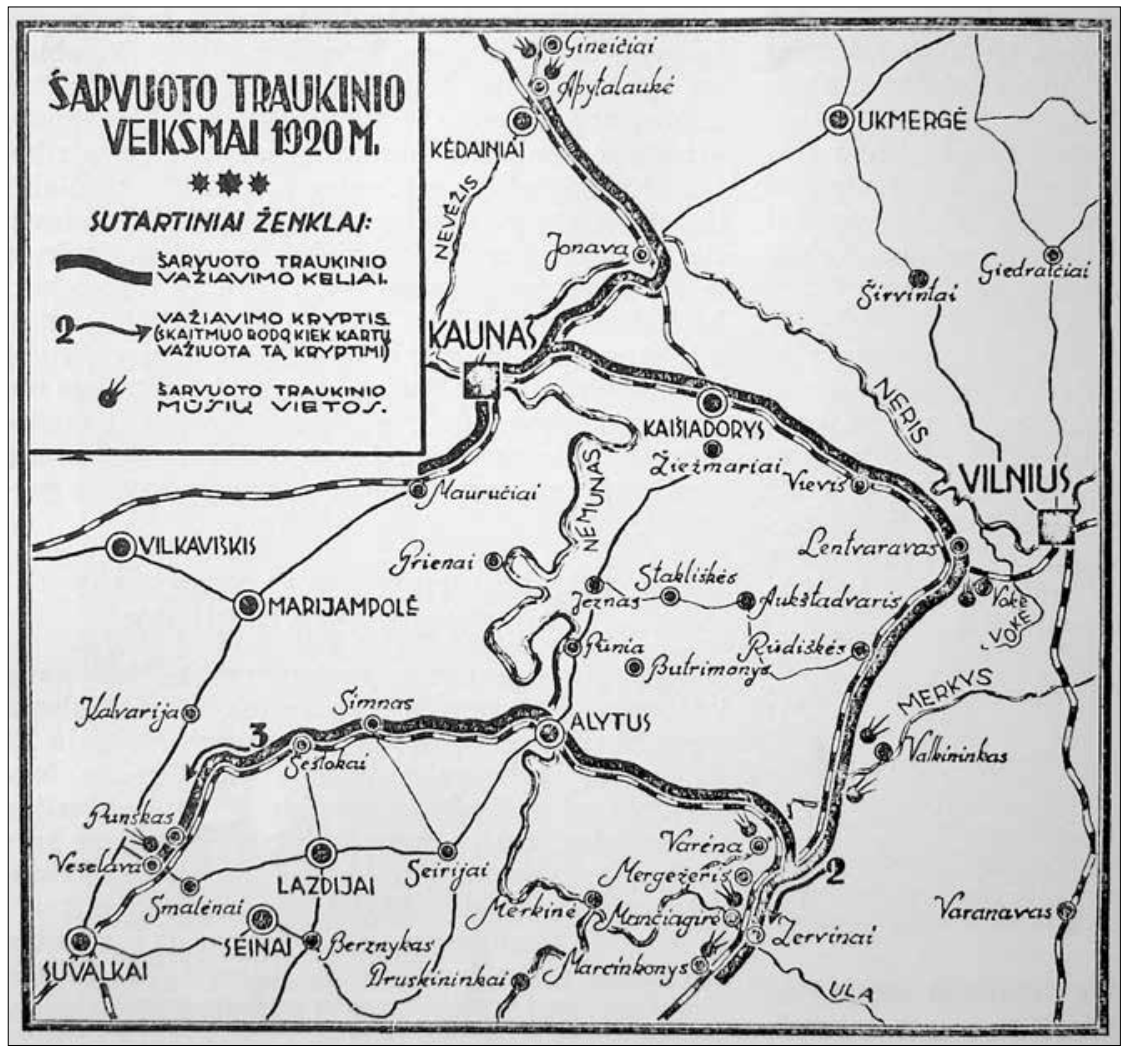

1920 m. Lietuvos Respublikos KAM šarvuotojo traukinio judejimo ir kautynių schema O. Žadvydas, Šarvuočiu rinktiné, Karys, 1970, Nr. 7, p. 206 


\section{2. ŠARVUOTŲJŲ TRAUKINIŲ DALINIO ORGANIZACINĖ STRUKTŪRA IR PERSONALO SUDE்TIS}

\subsection{Organizacinè struktūra, karių skaičius ir sudètis}

1920 m. rugpjūčio 25 - $1921 \mathrm{~m}$. liepos $31 \mathrm{~d}$. buvo naudojamas tik vienas šarvuotasis traukinys - „Gediminas“. Tačiau jo pagrindu, papildžius šarvuotaisiais garvežiais, platformomis ir ginkluote, $1921 \mathrm{~m}$. rugpjūčio $1 \mathrm{~d}$. buvo suformuotas šarvuotųjų traukinių pulkas. Jị sudarè pulko štabas ir trys šarvuotieji traukiniai - „Gediminas“, „Kęstutis“ ir "Algirdas“.

Netrukus suformuotam pulkui vadovauti buvo paskirtas plk. ltn. J. Kraucevičius ${ }^{66}$. Eiti 1-ojo šarvuotojo traukinio „Gediminas“ vado pareigas patikèta kpt. P. Gudeliui ${ }^{67}, 2$-ojo šarvuotojo traukinio

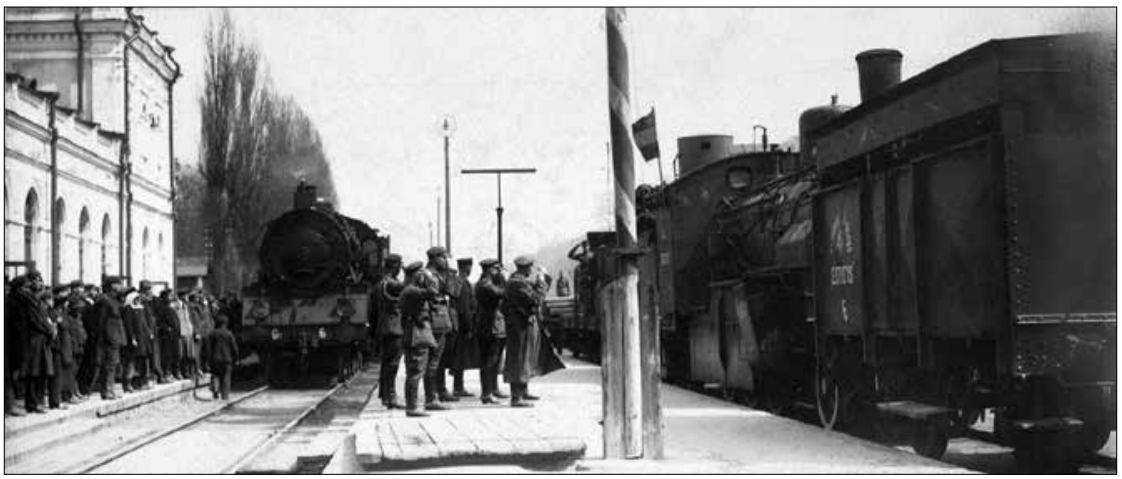

Lietuvos karinè vadovybė priima šarvuotųjų traukinių pulko paradą. $1922 \mathrm{~m}$.

LCVA Fs P-20195

66 Isakymas kariuomenei Nr. 181/2, Kaunas, 1921 m. rugpjūčio 4 d; 1924 m. Lietuvos Respublikos KAM 1. e. Šarvuočių rinktinès vado pareigas plk. ltn. J. Kraucevičiaus atestacijos lapas, ten pat, f. 930, ap. 5, b. 1361a, 1. 10.

6719211010 Lietuvos Respublikos KAM šarvuotųjų traukinių pulko kpt. Petro Gudelio tarnybos lapas, ten pat, ap. 2G, b. 180, 1. 6 ap-7. 


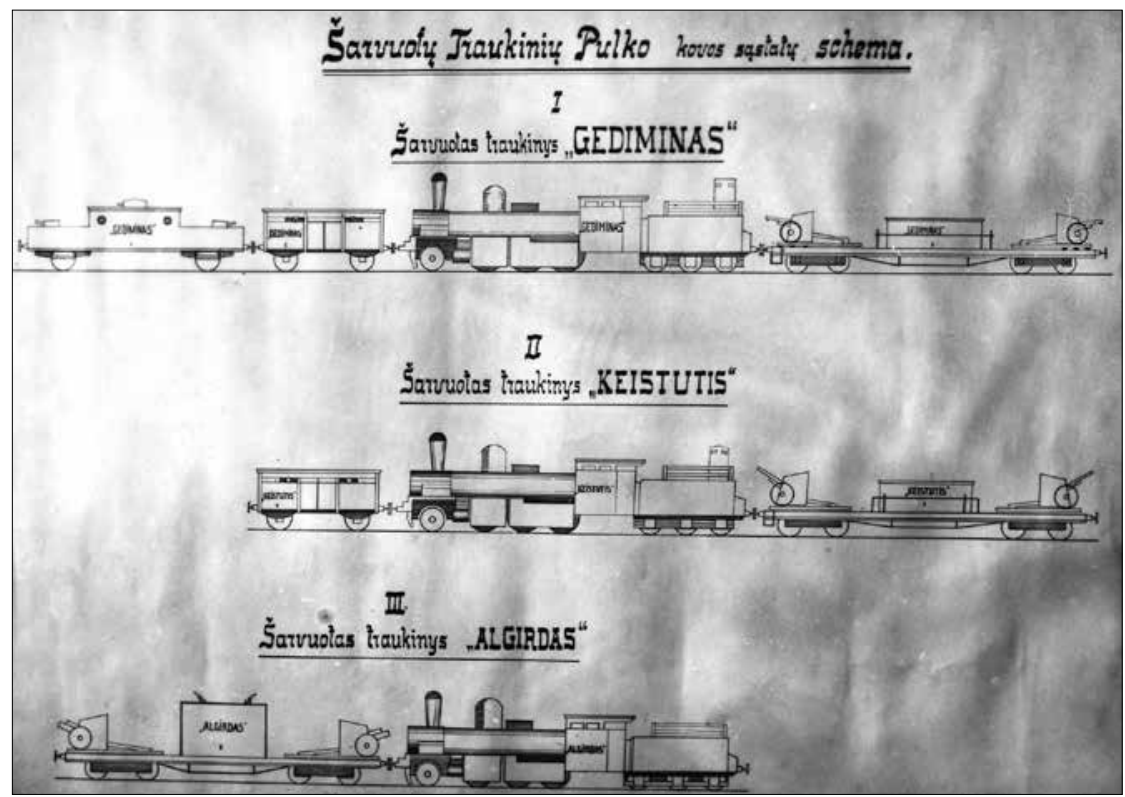

Šarvuotųjų traukinių pulko kovinès dalies (sąstato) schema. Autorius - ltn. Simas Sidabras, fotografas - Juozas Timukas. $1923 \mathrm{~m}$. kovo $3 \mathrm{~d}$.

VDKM negatyvu rinkiniai, $N-738$

„Kęstutis“ - ltn. A. Sidabrui, laikinai ị 3-iojo šarvuotojo traukinio „Algirdas" vado pareigas buvo paskirtas ltn. J. Toliušis ${ }^{68} .1921 \mathrm{~m}$. rugpjūčio 1 d., pagal etatus, pulke buvo 21 karininkas ir karo valdininkas ir 182 kareiviai $^{69}$. Faktiškai pulke visada tarnavo 100-150 karių.

Vèliau laikinaisiais ir nuolatiniais šarvuotojo traukinio „Gediminas“ vadais buvo paskirti kpt. Nikolajus Rozanovas ${ }^{70}$, vyr. ltn. Henrikas

68 Šarvuotų traukinių pulkui įsakymas Nr. 2/2, Kaunas, 1921 m. rugpjūčio 2 d., ten pat, f. 828, ap. 1, b. 13, 1. 3-3 ap.

69 1920-1922 m. Lietuvos Respublikos KAM šarvuotųjų traukinių pulko istorinė apžvalga, ten pat, b. 8, 1. 22.

70 Šarvuotų traukinių pulkui įsakymas Nr. 6/2, Kaunas, 1923 m. sausio 9 d., ten pat, f. 828, ap. 1, b. 22, 1. 11; 19230730 Lietuvos Respublikos KAM Šarvuočių rinktinès šarvuotųjų traukinių pulko kpt. N. Rozanovo tarnybos lapas, ten pat, f. 930, ap. 2R, b. 85, 1. 2-2 ap. 
Šarvuotųjų traukinių pulko štabas tarnybos metu. 1922 m. Pirmoje eilèje iš kairès: raštvedys karo valdininkas Mikas Cicenas, 4-as - adjutantas ltn. Kazys Pašys, toliau vadas plk. ltn. Jonas Kraucevičius VDKM nuotrauku rinkiniai, Fa-14934/3

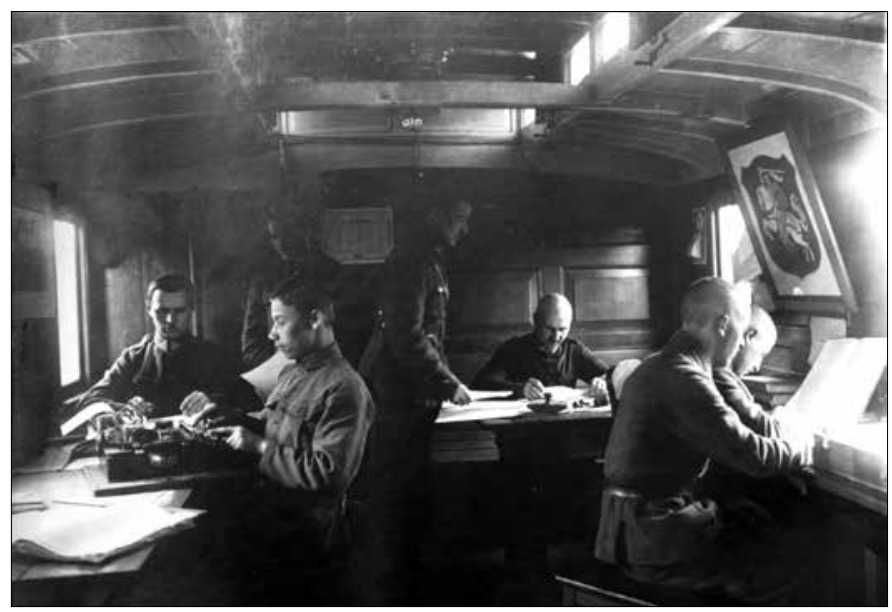

Bliumentalis $^{71}$, kpt. Kazys Abaras (Abaravičius) ${ }^{72}$, mjr. Adolfas Zubavičius $^{73}$, šarvuotojo traukinio „Kęstutis“ vadais - vyr. ltn. A. Sidabras ${ }^{74}$, vyr. Itn. Leonas Virbickas ${ }^{75}$, kpt. H. Bliumentalis ${ }^{76}$, vyr. ltn. Bronius Ambraziejus $^{77}$, šarvuotojo traukinio „Algirdas“ - kpt. Juozas Musteikis ${ }^{78}$ ir vyr. ltn. H. Bliumentalis ${ }^{79}$.

7119280428 Lietuvos Respublikos KAM 2-ojo artilerijos pulko kpt. H. Bliumentalio tarnybos lapas, ten pat, ap. 2B, b. 194, 1. 3-3 ap; Lietuvos kariuomenes karininkai 1918-1953, Vilnius, 2002, t. 2, p. 196.

72 Ten pat, p. 20.

7319340115 Lietuvos Respublikos KAM Šarvuočių rinktinès šarvuotojo traukinio „Gediminas“ mjr. A. Zubavičiaus tarnybos lapas, $L C V A$, f. 930, ap. 2Z, b. 52, 1. 11.

74 Šarvuočių rinktinei įsakymas Nr. 2/4, Kaunas, 1924 m. sausio 2 d., ten pat, f. 828, ap. 1, b. 24, 1. 5; 19280319 Lietuvos Respublikos KAM 2-ojo artilerijos pulko kpt. A. Sidabro tarnybos lapas, ten pat, f. 930, ap. 8, b. 93, 1. 304-1. 304 ap.

75 Šarvuočių rinktinei ịsakymas Nr. 295/2, Kaunas, 1924 m. gruodžio 30 d., ten pat, f. 828 , ap. 1, b. $25,1.82$.

7619280428 Lietuvos Respublikos KAM 2-ojo artilerijos pulko kpt. H. Bliumentalio tarnybos lapas, ten pat, f. 930, ap. 2B, b. 194, 1. 3 ap.

77 Lietuvos kariuomenes karininkai 1918-1953, Vilnius, 2002, t. 2, p. 49.

78 Lietuvos kariuomenès karininkai 1918-1953, Vilnius, 2005, t. 5, p. 294.

7919280428 Lietuvos Respublikos KAM 2-ojo artilerijos pulko kpt. H. Bliumentalio tarnybos lapas, LCVA, f. 930, ap. 2B, b. 194, 1. 3 ap; Lietuvos kariuomenés karininkai 1918-1953, t. 2, p. 196. 


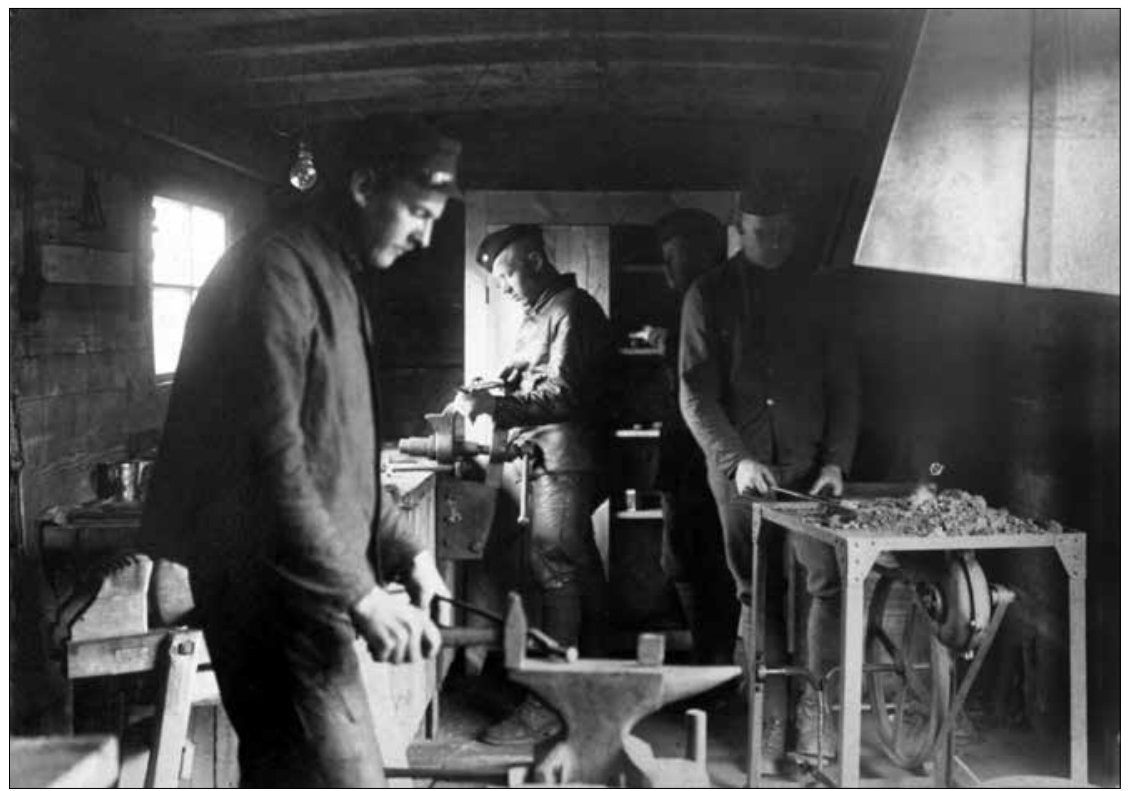

Šarvuotojo traukinio „Gediminas“ kariai dirbtuvėse. Apie 1922 m.

VDKM nuotrauku rinkiniai, Fa-14934/5

Nuo $1921 \mathrm{~m}$. rugpjūčio $1 \mathrm{~d}$. šarvuotojo traukinio dalinio vadovybè buvo pavaldi artilerijos viršininkui, nuo 1924 m. sausio 1 d. - Šarvuočių rinktinès vadui. Pastarasis buvo pavaldus artilerijos viršininkui, nuo 1925 m. rugsèjo 5 d. - II karinès apygardos viršininkui, nuo 1927 m. birželio $15 \mathrm{~d}$. - karo technikos viršininkui ${ }^{80}$.

Išnagrinejjus aptariamojo laikotarpio šarvuotųjų traukinių pulko etatinę sudètị teigtina, kad jo štabe tarnavo pulko vadas, mechanikas, sprogdintojas, pulko vado adjutantas (visi karininkai), ùkio vedejas ir raštvedys (karo valdininkai), viršila (viršila), sprogdintojai (1 vyr. puskarininkis, 2 grandiniai ir 6 eiliniai kareiviai), artilerijos sandèlio vedèjas

(vyr. puskarininkis) ir inžinerijos sandèlio vedejjas (vyr. puskarininkis),

802014 m. Lietuvos centrinio valstybès archyvo pažyma apie Šarvuočių rinktinès fondą Nr. 828, <http://www.archyvai.lt/lt/fondai/kariuomene/lcva_f828.html> [žiūrèta: $20150107]$. 


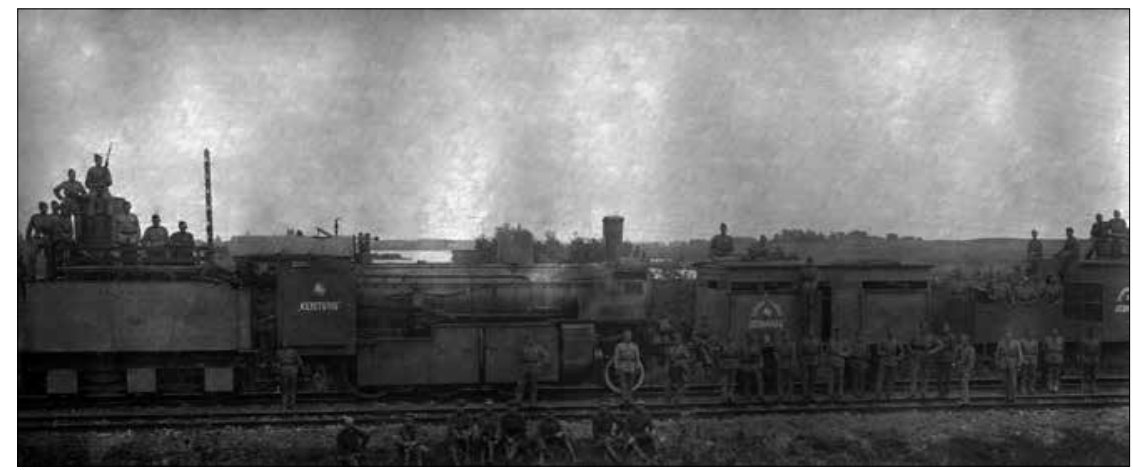

Šarvuotųjų traukinių „Kęstutis“ ir „Gediminas“ igula laisvu tarp mokymų metu. 1921-1922 m. VDKM nuotrauku rinkiniai, Fa-14934/47

ūkvedys (vyr. puskarininkis), raštininkai (1 vyr. puskarininkis ir 3 j. puskarininkiai), sanitarijos puskarininkis (vyr. puskarininkis), mechanikas (1 vyr. puskarininkis / laisvai samdomas civilis tarnautojas), 2 prožektoriaus aptarnavimo specialistai (grandiniai), šaltkalvis (j. puskarininkis) ir kalvis (grandinis), dailidè (grandinis), siuvejjas (eilinis), 2 kurpiai (eiliniai) ir 2 virẻjai (eiliniai), artelininkas ${ }^{81}$ (eilinis), geležinkelio amatininkai (2 j. puskarininkiai ir 7 eiliniai), geležinkelio meistras (vyr. puskarininkis). Iš viso štabe buvo 4 karininkai, 2 karo valdininkai, 1 viršila, 8 vyresnieji ir 8 jaunesnieji puskarininkiai, 7 grandiniai ir 20 eilinių ${ }^{82}$.

1-ajam šarvuotajam traukiniui „Gediminas“ pagal patvirtintus etatus turejo vadovauti majoras. Jam pavaldūs buvo dviejų artilerijos platformų vadai ir vieno kulkosvaidžių vagono vadas (visi vyresnieji leitenantai), 2 jaunesnieji karininkai, artileristai (2 vyr. ir 4 j. puskarininkiai, 4 grandiniai ir 22 eiliniai), kulkosvaidininkai ( 1 vyr. ir 1 j. puskarininkis, 2 grandiniai ir 4 eiliniai), telefonistai ( $1 \mathrm{j}$. puskarininkis, 1 grandinis ir 2 eiliniai), garvežio mašinistai ( 2 vyr. puskarininkiai) ir jų padèjèjai ( 2 j. puskarininkiai), garvežio kūrikai (2 grandiniai), stebėtojai (2 grandiniai ir 2 eiliniai), sanitarijos puskarininkis ( $1 \mathrm{j}$. puskarininkis). Iš viso jame tarnavo 6 karininkai, 5 vyresnieji ir 9 jaunesnieji puskarininkiai, 11

\footnotetext{
81 Artelininkas - îvairius ūkio darbus dirbantis asmuo.

821921 m. Lietuvos Respublikos KAM Šarvuočių rinktinès taikos meto etatai, LCVA, f. 929 , ap. 5 , b. $43,1.55$.
} 


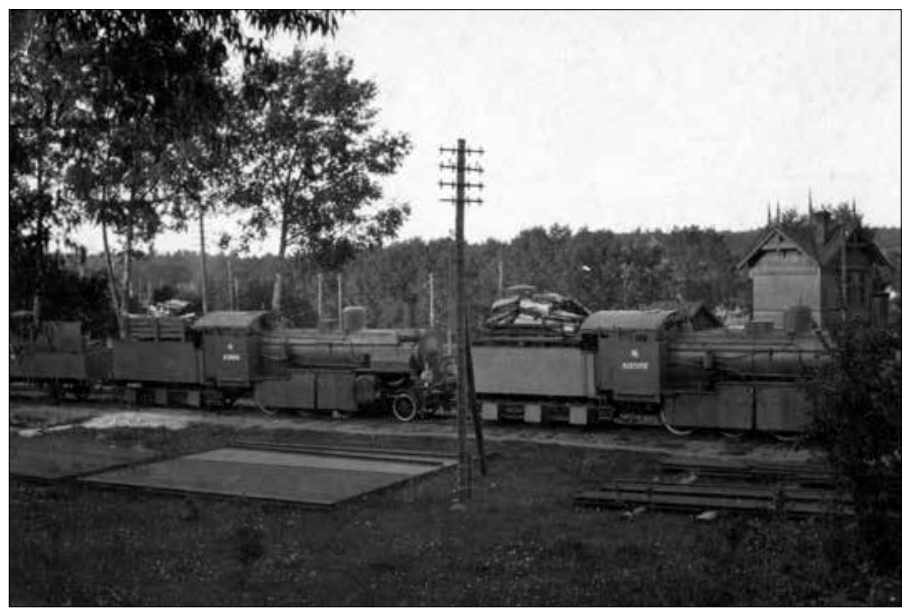

Šarvuotojo

traukinio

„Kęstutis“

garvežys ir

šarvuotasis

traukinys

"Algirdas“

geležinkelio

stotyje.

1921-1923 m.

Geležinkeliu

muziejaus

rinkiniai,

GMIf-120

grandinių ir 30 eilinių ${ }^{83}$.

2-ajam šarvuotajam traukiniui „Kęstutis“ turèjo vadovauti kapitonas. Jo artilerijos platformai ir kulkosvaidžių vagonui vadovavo karininkai (2 vyr. leitenantai), tarnavo 1 jaunesnysis karininkas, artileristai (1 vyr., 2 j. puskarininkiai ir 2 grandiniai, 11 eilinių), kulkosvaidininkai (1 vyr. ir 1 j. puskarininkiai, 2 grandiniai ir 4 eiliniai), telefonistai ( $1 \mathrm{j}$. puskarininkis ir 1 grandinis, 2 eiliniai), garvežio mašinistai ( 2 vyr. puskarininkiai), jų padejejjai (2 j. puskarininkiai), garvežio kūrikai (2 grandiniai), stebètojai (2 grandiniai ir 2 eiliniai), sanitarijos puskarininkis ( $1 \mathrm{j}$. puskarininkis). Iš viso - 4 karininkai, 4 vyresnieji ir 7 jaunesnieji puskarininkiai, 9 grandiniai ir 19 eilinių ${ }^{84}$.

3-iajam šarvuotajam traukiniui „Algirdas“ turejo vadovauti majoras ir dviejų artilerijos platformų vadai - vyresnieji leitenantai, taip pat tarnavo dar 2 jaunesnieji karininkai, artileristai (2 vyr. ir 3 j. puskarininkiai, 3 grandiniai ir 16 eilinių), kulkosvaidininkai ( $1 \mathrm{j}$. puskarininkis ir 1 grandinis, 2 eiliniai), telefonistai ( $1 \mathrm{j}$. puskarininkis, 1 grandinis ir 2 eiliniai), garvežio mašinistai ( 2 vyr. puskarininkiai), jų padejejejai ( $2 \mathrm{j}$. puskarininkiai), garvežio kūrikai (2 grandiniai), stebėtojai (2 grandiniai ir 2 eiliniai), sanitarijos puskarininkis ( $1 \mathrm{j}$. puskarininkis). Iš viso - $5 \mathrm{ka}$ -

\footnotetext{
83 Ten pat, 1. 55 ap.

84 Ten pat, 1. 55 ap.
} 
rininkai, 4 vyresnieji ir 8 jaunesnieji puskarininkiai, 9 grandiniai ir 22 eilinių ${ }^{85}$. Tačiau minèti etatai niekada visi nebuvo užimti.

Pabrèžtina, kad traukinio vadas vadovavo rikiuotès, technikos ir ūkio tarnyboms. Jo padejejejas ir adjutantas organizavo šarvuotojo traukinio ir geležinkelio tarnybą, apsaugą, vadovavo nustatant išorinius ryšius, vykdè visus kitus vado nurodymus. Karininkas mechanikas prižiūrèjo riedmenis, geležinkelį, kaip jie taisomi, ryšius, signalizaciją ir apšvietimą. Karininkas sprogdintojas dirbo su sprogstamąja medžiaga ir įranga. Artilerijos platformos vadas, kuriam talkino jaunesnieji karininkai, ir kulkosvaidžių vagono vadas, vykdė kovos užduotis, prižiūrèjo jiems priskirtą ginkluotę ${ }^{86}$. Kareivių komandai vadovavo viršila. Ją sudare puskarininkiai ir kareiviai - artileris-

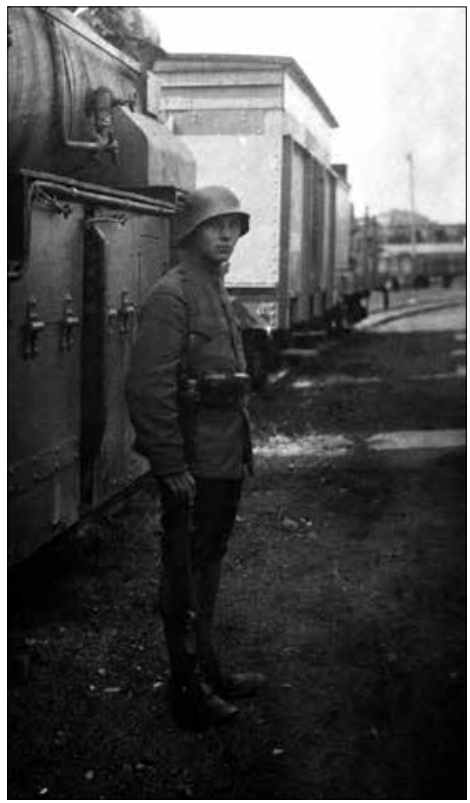

Šarvuotojo traukinio „Gediminas“ karys eina sargybinio pareigas. Apie $1921 \mathrm{~m}$.

VDKM nuotrauku rinkiniai, Fa-14934/9 tai ir kulkosvaidininkai, telefonistai, sprogdintojai, sekẻjai, garvežio mašinistai, jų padejjejjai, drezinos vairuotojai, geležinkelio meistras ir amatininkai, elektromonteris, sanitarijos puskarininkis, apšvietimo specialistas, garvežio kūrikai, konduktorius, motociklininkas, raštininkai, sandèlininkai, dailidè, šaltkalvis, siuvejjas, batsiuvys ir virejai.

Šarvuotajj traukinị taikos metu sudarè tos pačios dvi pagrindinès dalys. Tačiau kovinèje dalyje, be garvežio, galèjo būti 1-4 artilerijos platformos, ginkluotos patrankomis ir haubicomis, 1-2 kulkosvaidžių vagonai, ginkluoti kulkosvaidžiais, 1-2 (šarvuota ir nešarvuota) drezinos, skirtos žvalgybai. Bazinejje dalyje buvo keliolika keleivinių ir specialiosios paskirties prekinių vagonų, kontrolinès platformos su geležinkelio me-

85 Ten pat, 1. 55 ap-56.

86 Instrukcija šarvuotiems traukiniams, p. 8-10. 


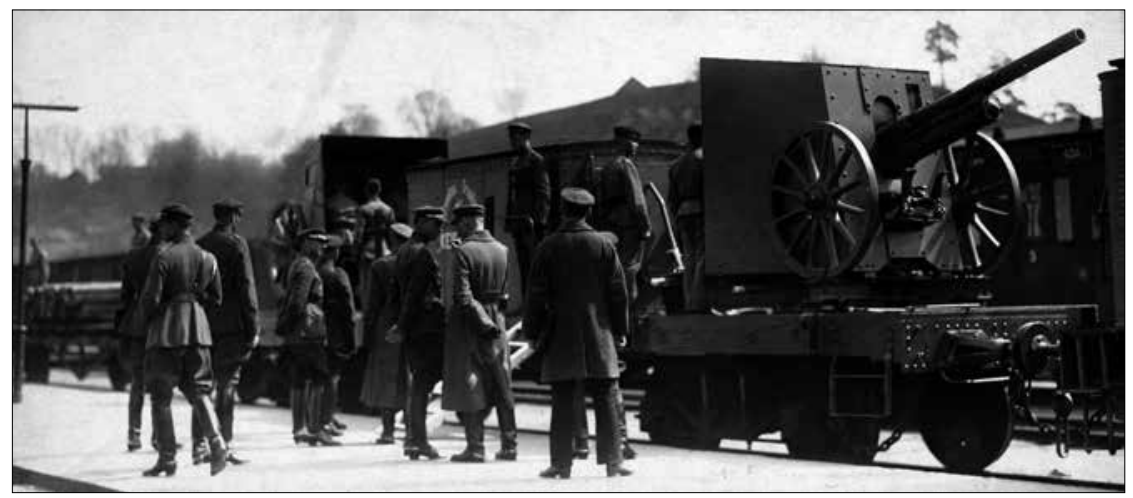

Lietuvos kariuomenès vadovybė apžiūri šarvuotąji traukinị „Kęstutis“. 1922 m. LCVA Fs, P-20194

džiaga ir pagalbinèmis priemonėmis, kabinamos priekyje ir gale ${ }^{87}$, kad platformos neužvažiuotų ant galimo sprogmens. Bazinis sąstatas buvo bendras visam traukiniui (daliniui) ${ }^{88}$.

Šalia šarvuotųjų traukinių turèjo veikti du pagalbiniai traukiniai, sudaryti iš garvežio, dviejų vagonų ir kontrolinių platformų ${ }^{89}$, techninès ${ }^{90}$ ir ūkinès ${ }^{11}$ paskirties traukiniai, turintys šarvuotą vagoną, ginkluotą pabūklu ir kulkosvaidžiais, kuriame būdavo atitinkama karių igula ${ }^{92}$.

Lietuvos kariuomenès šarvuotieji traukiniai galèjo būti priskirti tarpiniam (tarp lengvųjų ir sunkiųjų) šarvuotųjų traukinių tipui, nors joje veikè kaip taktinis vienetas - šarvuotụjų traukinių pulkas (kitų šalių kariuomenèse jis galèjo atitikti tik šarvuotųjų traukinių batalioną). Tačiau

\footnotetext{
87 Ten pat, p. 3, 30.

88 [J.] Kraucevičius, Plienu gaubta kariuomenè, Karys, p. 360.

89 Ten pat, c. 23-24.
}

90 Šarvuotojo pagalbinio traukinio techninę dalị sudare garvežys, keletas keleivinių ir prekinių vagonų dirbtuvèms, komandai ir sandèliams (amunicijos, inžinerijos, kuro ir t. t.) ikkurdinti, platformos kroviniams, drezinai gabenti, atsarginis šarvuotasis traukinys.

91 Šarvuotojo pagalbinio traukinio ūkinę dalị sudarẻ garvežys, keletas keleivinių ir prekinių vagonų, skirtų karininkams gyventi, maistui gaminti, valgyti, ginklų saugyklai, sandèliui, ligoninei, pirčiai ịrengti, ir platformų kroviniams gabenti.

92 А. В. Шавровъ, Бронепоздюзда. Значеніе, вооруженіе, организачія и тактика бронепоздьздовъ, с. 29-30. 


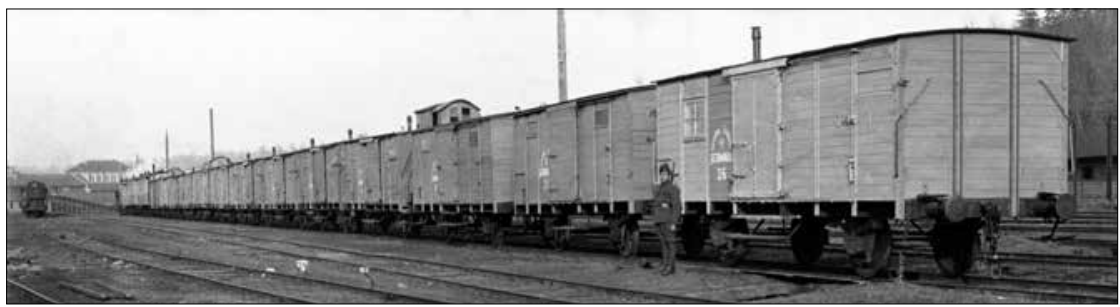

Šarvuotojo traukinio „Gediminas“ sargybinis saugo traukinio bazinès dalies prekinius vagonus. Apie 1921 m. VDKM nuotrauku rinkiniai, Fa-14934/22

Lietuvos kariuomenèje tokia trijų traukinių grupé puikiai tiko dalyvauti karo veiksmuose.

$1924 \mathrm{~m}$. sausio $1 \mathrm{~d}$. šarvuotųjų traukinių pulkas buvo reorganizuotas ị šarvuotụjų traukinių batalioną. Jị sudarè traukiniai „Gediminas“ ir „Kęstutis“"93. Šarvuotasis traukinys „Algirdas“ buvo likviduotas, o jo igula ir karinis turtas priskirtas traukiniui „Gediminas“94. Šarvuotųjų traukinių batalionui vietoje ilgamečio dalinio vado plk. ltn. J. Kraucevičiaus, kuris buvo paskirtas eiti Šarvuočių rinktinès vado pareigas ${ }^{95}$, pradejjo vadovauti kapitonas, vèliau - majoras Juozas Musteikis ${ }^{96}$. Tuo metu šarvuotųjų traukinių batalione buvo 11 karininkų, 2 karo valdininkai ir 89 kareiviai $^{97}$.

1-ajame šarvuotajame traukinyje "Gediminas“ tarnavo karininkas (majoras), 2 artilerijos platformos vadai ir 1 kulkosvaidžių vagono vadas (visi vyr. leitenantai), artileristai (1 viršila ir 1 vyr. puskarininkis, 4 j. puskarininkiai, 4 grandiniai ir 14 eiliniu), kulkosvaidininkai (1 vyr. puskarininkis, 2 j. puskarininkiai, 2 grandiniai ir 9 eiliniai), telefonistai (1 j. puskarininkis, 1 grandinis ir 2 eiliniai), garvežio mašinistas (1 vyr.

93 Šarvuotų traukinių pulkui ịsakymas Nr. 285/2, Kaunas, 1923 m. gruodžio 21 d., LCVA, f. 828, ap. 1, b. 22, 1. 276; Šarvuotų traukinių pulkui ịsakymas Nr. 285/3, Kaunas, 1923 m. gruodžio 21 d., ten pat, 1. 276.

94 Šarvuotų traukinių pulkui įsakymas Nr. 285/4, Kaunas, 1923 m. gruodžio 21 d., ten pat; Šarvuotų traukinių pulkui ịsakymas Nr. 288/2, Kaunas, 1923 m. gruodžio 27 d., ten pat, 1. 277 ap.

95 Lietuvos kariuomenès karininkai 1918-1953, Vilnius, 2004, t. 4, p. 266.

96 Šarvuočių rinktinei įsakymas Nr. 2/2, Kaunas, 1924 m. sausio 2 d., LCVA, f. 828, ap. 1, b. $24,1.4$ ap.

97 Šarvuočių rinktinei įsakymas Nr. 1/3, Kaunas, 1923 m. gruodžio 27 d., ten pat, 1. 1-3. 


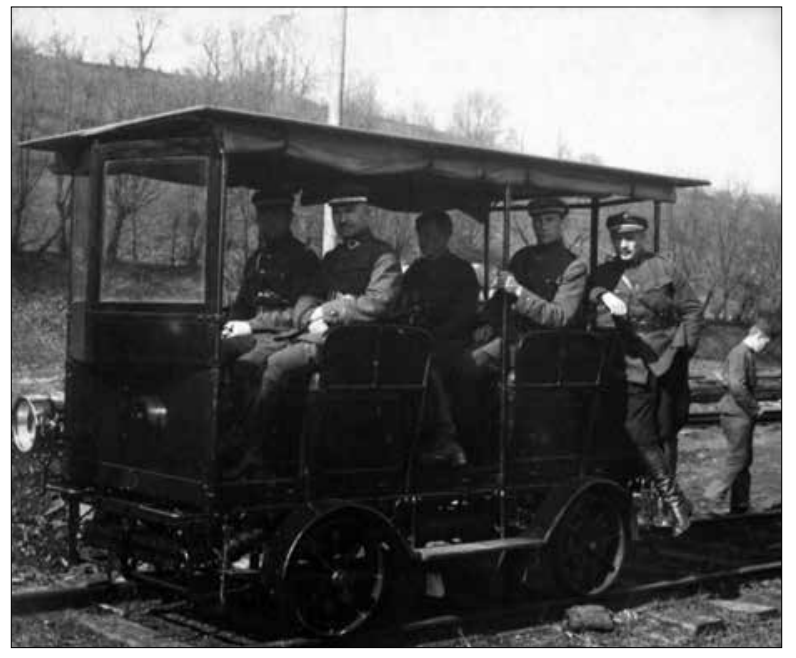

Šarvuotųjų traukinių pulko vadovybė važiuoja drezina. Žemoji Freda, Kaunas. 1922 m. LCVA Fs, P-20197

puskarininkis) ir jo padejejejas (1 j. puskarininkis), garvežio kūrikas (1 grandinis), motociklininkas (1 grandinis), konduktoriai (6 eiliniai), geležinkelio meistras ( $1 \mathrm{j}$. puskarininkis), geležinkelio amatininkai ( $3 \mathrm{j}$. puskarininkiai ir 3 eiliniai), elektromonteris ( 1 vyr. puskarininkis), raštininkas (1 j. puskarininkis), siuvejjas (1 eilinis) ir batsiuvys ( 1 eilinis), virèjai (2 eiliniai). Iš viso buvo 4 karininkai, 1 viršila, 3 vyr. puskarininkiai, 13 j. puskarininkių, 9 grandiniai ir 38 eiliniai ${ }^{98}$.

2-ojo šarvuotojo traukinio „Kęstutis“ igulą sudarè: vadas karininkas (majoras), artilerijos platformos ir kulkosvaidžių vagono vadai (vyr. leitenantai), artileristai (1 viršila, 1 vyr. puskarininkis, 2 j. puskarininkiai, 2 grandiniai ir 3 eiliniai), kulkosvaidininkai ( $1 \mathrm{j}$. puskarininkis, 1 grandinis ir 6 eiliniai), telefonistai ( $1 \mathrm{j}$. puskarininkis, 1 grandinis ir 2 eiliniai), garvežio mašinistas (1 vyr. puskarininkis) ir jo padejejjas ( 1 j. puskarininkis), garvežio kūrikas (1 grandinis), motociklininkas (1 grandinis), konduktorius (1 eilinis), ūkvedys (1 vyr. puskarininkis). Iš viso - 3 karininkai, 1 viršila, 3 vyr. puskarininkiai, 5 j. puskarininkiai, 6 grandiniai ir 17 eilinių 99.

9819251231 Lietuvos Respublikos KAM Šarvuočių rinktinès taikos meto etatai, ten pat, f. 929 , ap. 5 , b. $165,1.31$.

9919251231 Lietuvos Respublikos KAM Šarvuočių rinktinès taikos meto etatai, ten pat, 1. 31 ap. 


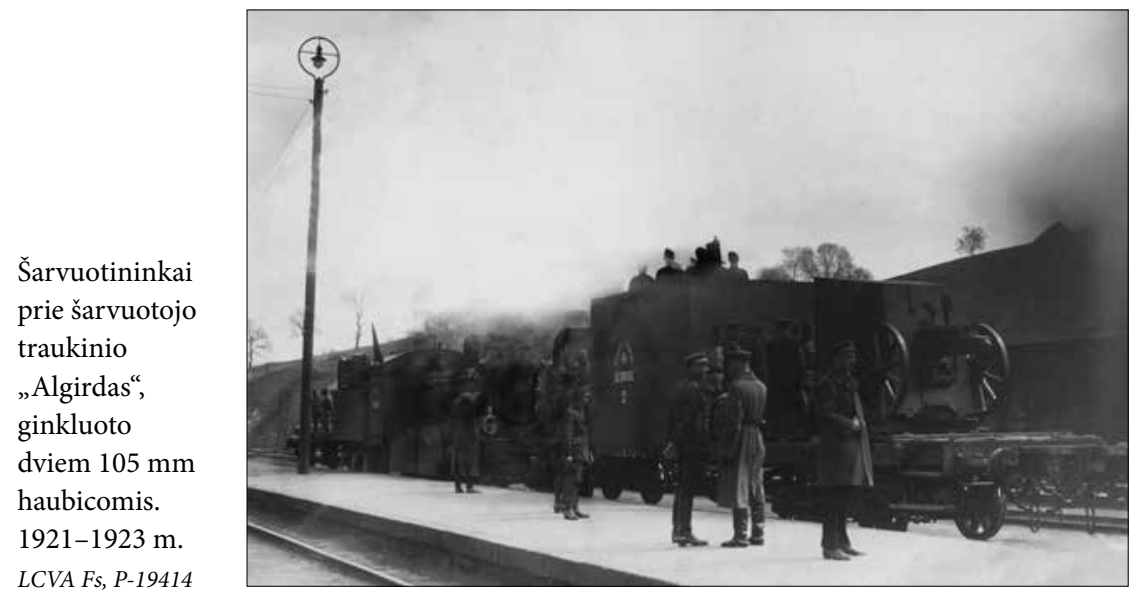

Šarvuotieji traukiniai stovejo Žemutinèje Fredoje, Žemuosiuose Šančiuose ir Linksmakalnyje ${ }^{100}$. Nuo 1925 m. laikinai, o nuo $1927 \mathrm{~m}$. gruodžio nuolatinai reorganizuotas kovinis vienetas buvo dislokuotas viename didžiausių Lietuvos geležinkelių mazgų - Radviliškyje. Dalinio vadovybei nauja dislokacijos vieta kèlè nepatogumų: naujos bazavimosi vietos aplinka buvo skurdi, pelketa, nedaug miškingos vietovés, trūko tinkamų patalpų karių tarnybai, kilo aprūpinimo ir saugumo problemų, nes neturèta ir atskiros karinès teritorijos. Net šarvuotojo traukinio dalys stovejjo trijose vietose: garvežiai - atskirai nuo kovinès dalies prie geležinkelių kuopos garvežių depo ( $300 \mathrm{~m}$ atstumu), kovinè dalis - po atviru dangumi prie vienų kareivinių, o bazinè dalis - kitame miestelio gale prie kitu geležinkelių kuopos kareivinių. Problemų kilo ir dèl išvažiavimo iš depo, nes reikejjo važiuoti apsisukimo ratu, o šiam sugedus, garvežiai net negalèjo pajudèti iš vietos. Negalèjo garvežiai stovèti ir šalia kovinès dalies, nes buvo per trumpa atsargine kelio atšaka ${ }^{101}$. Vykdant priskirtas tam tikras funkcijas, šarvuotieji traukiniai neretai stovedavo Taurageje ir čia dažnai

100 1934-1937 m. A. Sidabro atsiminimai apie Šarvuočių rinktinę, LNMMB RK RSK, f. $29-733,1.6$.

10119300301 Lietuvos Respublikos KAM Šarvuočių rinktinès vado mjr. V. Asevičiaus raportas karo technikos viršininkui, ten pat, f. 1364, ap. 1, b. 177, 1. 36 ap-37; 19310602 Lietuvos Respublikos KAM Šarvuočių rinktinès vado mjr. V. Asevičiaus raportas karo technikos viršininkui, ten pat, 1. 80; 19300517 Lietuvos Respublikos KAM karo technikos viršininko plk. K. Popeliučkos raportas Vyriausiojo štabo valdybos viršininkui, ten pat, 1. 35. 


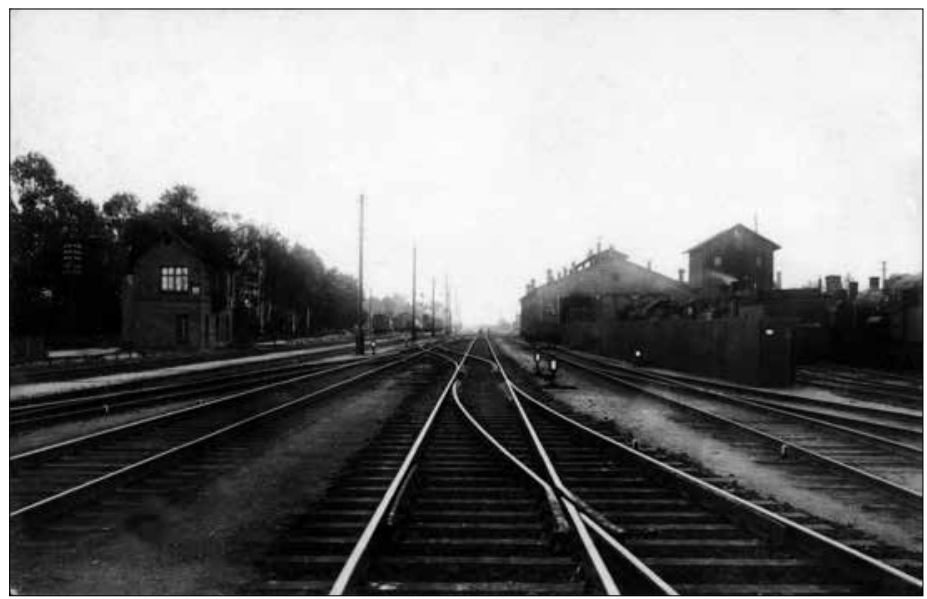

Radviliškio geležinkelio stotis. Apie $1931 \mathrm{~m}$. LCVA Fs, P-20554

buvo matomi pašalinių civilių asmenų. Pvz., ant atsarginių bėgių Tauragès geležinkelio stotyje stovintị traukinị fotografuodavo pravažiuojantys tarptautinio traukinio Berlynas-Maskva keleiviai ${ }^{102}$.

Dèl tokios padèties susidarydavo ir avarinès situacijos. Pvz., $1934 \mathrm{~m}$. spalio 3 d. Radviliškyje manevruodamas šarvuotasis traukinys susidūrẻ su taip pat manevruojančiu kitu traukiniu. Buvo nežymiai apgadintas jo garvežys, trys prekiniai vagonai. Pagrindinès nurodytos šio ịvykio priežastys - rūkas, šarvų „dundèjimas ir klebejjimas“, sutrukdęs išgirsti signalus, blogai veikiantis prožektorius, slidūs bėgiai, garvežio mašinisto ir jo padejejo nuovargis ir aplaidumas. Karinè vadovybè dalinio viršininkui pareiškè papeikimą, o garvežio mašinistui ir jo padejejjui skyrè keletą dienų arešto ${ }^{103}$.

Vis dèlto problemų buvo ir daugiau. Vieta, kur stovejo traukinio kovinè dalis, nebuvo tinkama artileristams mokyti, nes vienoje puseje buvo tvora, kitoje - trukdè medžiai ir statiniai. Be to, artilerijos priemonèms reikèjo nuolatinès priežiūros, papildomos šarvuotès ir ginkluotès. Trau-

10219340604 Lietuvos Respublikos KAM Vyriausiojo štabo valdybos I skyriaus einančio Organizacijos dalies vedejo pareigas gen. št. plk. ltn. A. Šovos raportas karo technikos viršininkui, $L C V A$, f. 828, ap. 1, b. 78, 1. 32 .

${ }^{103}$ Issakymas Šarvuočių rinktinei Nr. 356/1, Kaunas, 1934 m. gruodžio 30 d., ten pat, f. 828 , ap. 1, b. $73,1.236$ ap-238. 


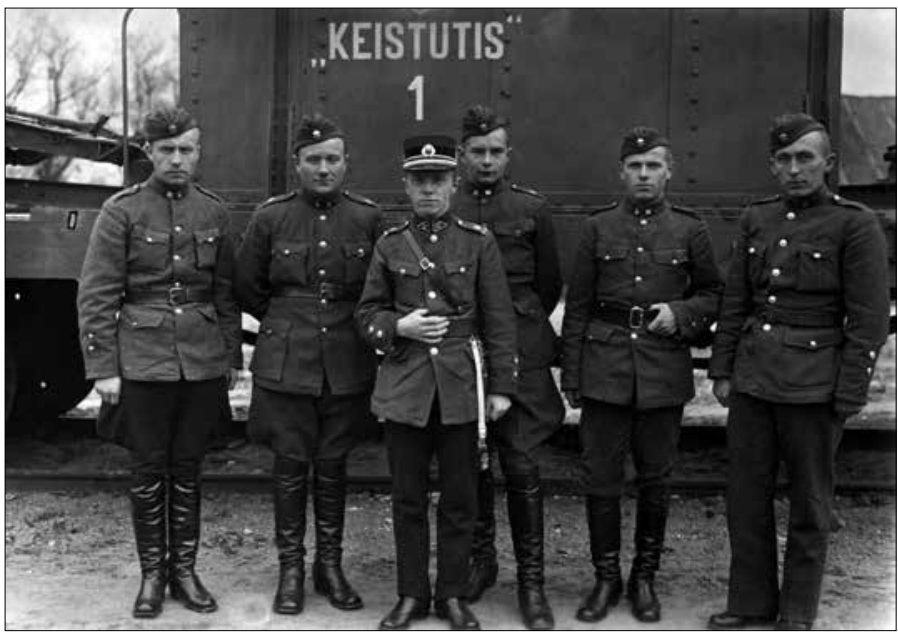

Šarvuotojo

traukinio

„Kęstutis“

igula prie

traukinio.

Apie $1927 \mathrm{~m}$.

LCVA

Fs, $P-19410$

kinys stovejjo toliau nuo Šarvuočių rinktinès štabo, o tai kẻlè nepatogumų organizuojant mokymus ir jų aprūpinimą. Todèl traukinių vadovybė puoselejo mintị grịžti ị Kauną. Net kita Kèdainiuose surasta vieta labiau tiko traukiniams dislokuoti, nes ten stovejo 2-asis artilerijos pulkas ${ }^{104}$.

1926 m. mažinant kariuomenę buvo galvojama apie šarvuotųjų traukinių dalinio išformavimą, traukiniai kurị laiką buvo laikomi Kèdainių geležinkelių depe, kurị saugojo 2-ojo artilerijos pulko kariai. Tačiau 1927 m. rugsėjo 16 d. šarvuotųjų traukinių batalionas buvo ne išformuotas, o performuotas ị kuopą. Ją sudarè tik šarvuotasis traukinys „Gediminas“. Reorganizuojant šarvuotujų traukinių batalioną šarvuotasis traukinys „Kęstutis“ taip pat buvo reorganizuotas ir likviduotas, o jo igula ir karinis turtas perkelti i traukinị „Gediminas“ ${ }^{105}$. 1927-1933 m. traukiniui vadovavo mjr. Kazys Abaras (Abaravičius) ${ }^{106}$, paskutinis traukinio vadas buvo mjr. Adolfas Zubavičius ${ }^{107}$.

10419310602 Lietuvos Respublikos KAM Šarvuočių rinktinès vado mjr. V. Asevičiaus raportas karo technikos viršininkui, ten pat, 1.80 ap.

10519390515 A. Tumo užrašyti 1919-1935 m. Šarvuočių rinktinès istoriniai bruožai, LNMMB RK RSK, f. 29-737, 1. 10.

${ }^{106}$ Lietuvos kariuomenes karininkai 1918-1953, t. 2, p. 20.

10719340115 Lietuvos Respublikos KAM Šarvuočių rinktinės šarvuotojo traukinio „Gediminas" mjr. A. Zubavičiaus tarnybos lapas, $L C V A$, f. 930, ap. 2Z, b. 52, 1. 11. 


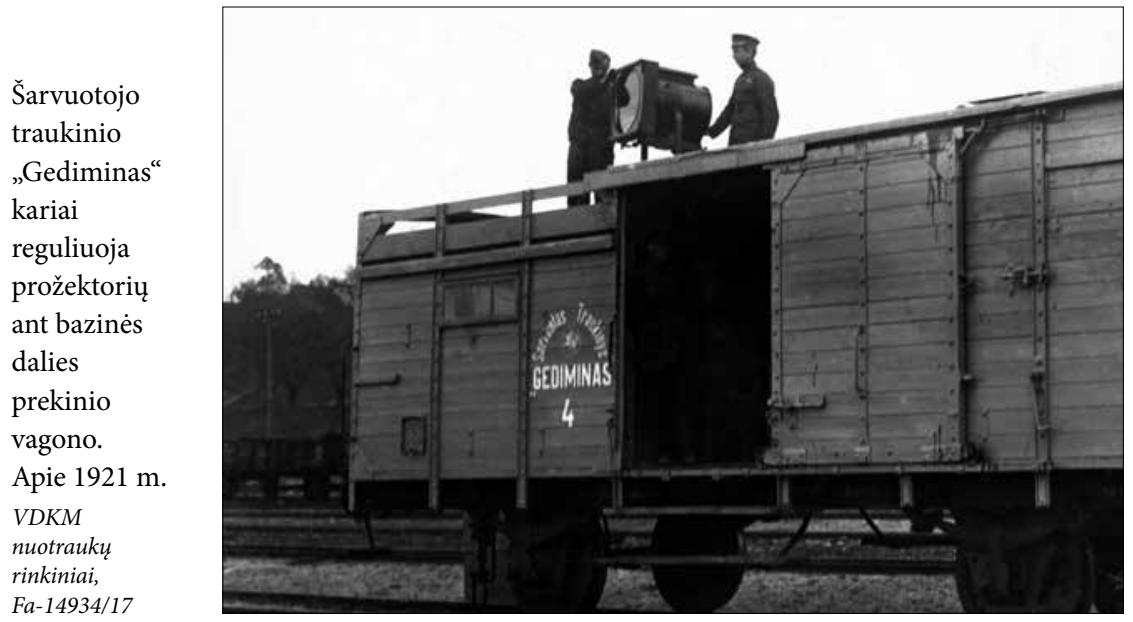

Be traukinio vado, jo personalą sudarè: vyresnysis karininkas (kapitonas), 2 artilerijos platformos vadai ir 1 kulkosvaidžių vagono vadas (leitenantai), viršila, artileristai (2 vyr. puskarininkiai, 4 j. puskarininkiai, 4 grandiniai ir 16 eilinių), kulkosvaidininkai (2 vyr. puskarininkiai, j. puskarininkis, 4 grandiniai ir 13 eilinių), sprogdintojai (1 vyr. puskarininkis ir 1 grandinis), telefonistai ( 1 vyr. ir $1 \mathrm{j}$. puskarininkiai, 1 grandinis ir 4 eiliniai), garvežio mašinistas (1 viršila), jo padejejjai ( 2 vyr. puskarininkiai), garvežio kūrikai (1 grandinis ir 1 eilinis), konduktorius (1 grandinis), drezinos vairuotojas (1 vyr. puskarininkis), jo padejejjas (1 j. puskarininkis), geležinkelio meistras (1 vyr. puskarininkis), geležinkelio amatininkas (1 grandinis ir 3 eiliniai), elektromechanikas (1 vyr. puskarininkis), raštininkai ( $1 \mathrm{j}$. puskarininkis ir 1 eilinis), sandelininkai (1 vyr. ir $1 \mathrm{j}$. puskarininkis, 1 grandinis), prožektoriaus aptarnavimo specialistai (1 vyr. ir 1 j. puskarininkis, 1 grandinis), dailide (1 grandinis), sanitarijos puskarininkis (1 vyr. puskarininkis), šaltkalvis (1 grandinis), siuvejas (1 eilinis) ir virejjai (2 eiliniai). Iš viso - 5 karininkai, 2 viršilos, 14 vyr. puskarininkių, 9 j. puskarininkiai, 17 grandinių ir 43 eiliniai ${ }^{108}$.

Šarvuotajji traukinị „Gediminas“ sudarè: 2 šarvuotieji garvežiai, 4 artilerijos platformos, 2 kulkosvaidžių vagonai, 2 kontrolinès platformos,

10819310317 Lietuvos Respublikos KAM Šarvuočių rinktinès taikos meto etatai, ten pat, f. 828 , ap. 1 , b. $35,1.5-6$. 


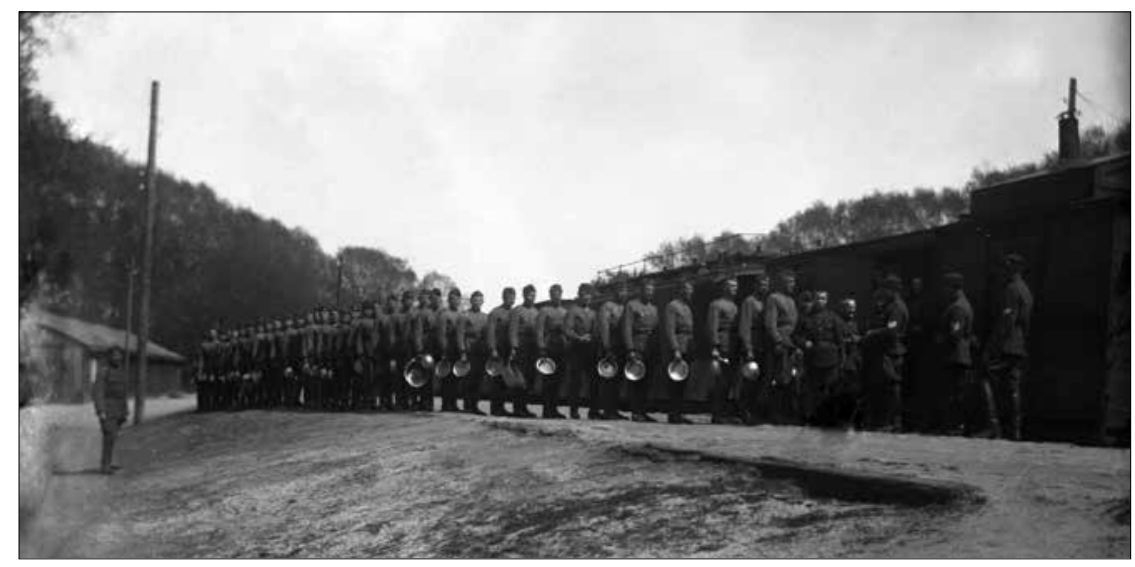

Šarvuotojo traukinio kariai laukia pietų prie traukinio virtuvès. Apie $1923 \mathrm{~m}$.

Lietuvos nacionalinès Martyno Mažvydo bibliotekos Retų knygų ir rankraščiu skyriaus (toliau - LNMMB RKRs) Zenono Ivinskio kolekcija, F-29-761/14

prekinis vagonas su įrengta elektros stotimi ir prožektoriumi ${ }^{109}$, po 1 prekinị vagoną, skirtą artilerijos, inžinerijos, maisto, kuro (malkų) sandėliui, virtuvei ịrengti, taip pat įvairioms kitoms reikmėms, 1 keleivinị I-II, 1 keleivinị III, 1 keleivini IV klasės vagoną - dalinio štabui, sargybai, klasei ir ambulatorijai ikurdinti, nes specialaus sanitarinio vagono nebuvo, 1 dengtą karių gyvenamąji vagoną ${ }^{110}$.

Šis šarvuotasis traukinys nebuvo visiškai sukomplektuotas. Vien jo bazinei daliai trūko vieno garvežio ir įrankių komplekto, I-II klasių vagono, sanitarinio vagono, dviejų III ir IV klasių, dviejų dengtų prekinių vagonų, dviejų pusvagonių anglims laikyti, dviejų prožektorių vagonų ir jos įrangos komplekto, o kovinei daliai - dviejų kontrolinių platformų, dviejų šarvuotųjų motorinių drezinų, dviejų motociklų su priekaba, keturių šarvuotụjų platformų keliams taisyti. Nebuvo įrengtos ir techninès dirbtuvès ${ }^{111}$.

1935 m. rugpjūčio $1 \mathrm{~d}$. de jure, o rugpjūčio $14 \mathrm{~d}$. de facto šarvuotụjų

109 Tik $1921 \mathrm{~m}$. buvo įsigytas prožektorius. $1934 \mathrm{~m}$. J. Kraucevičiaus atsiminimai apie 1920-1924 m. Šarvuočių rinktinę, LNMMB RK RSK, f. 29-730, 1. 21.

${ }^{110} 1931$ m. liepos mėn. Lietuvos Respublikos KAM Šarvuočių rinktinès papildomo inžinerijos etatinio turto žinios, LCVA, f. 828, ap. 1, b. 52, 1. 93.

${ }^{111} 19341112$ Lietuvos Respublikos KAM Šarvuočių rinktinès vado plk. ltn. Z. Talevičiaus raportas karo technikos viršininkui, ten pat, b. 78, 1. 77. 
traukinių kuopa buvo išformuota ${ }^{112}$. Traukinio garvežiai ir kai kurie vagonai buvo perduoti Susisiekimo ministerijai, o kitas turtas - 2-ojo inžinerijos bataliono geležinkelių kuopai ${ }^{113}$, kurioje likęs karinis inventorius buvo paskirtas statybos kuopoms, vietinèms ir kilnojamosioms dirbtuvèms.

\subsection{Technika, karių ginkluotè, ekipuotè ir tarnyba}

Taikos metu kariuomenejje liko ir Nepriklausomybès kovose naudota šarvuotoji karo technika (riedmenys). Ji buvo taisoma, keičiama nauja, taip pat iš naujo komplektuojama naudojant iš Geležinkelių valdybos gautas priemones. Šarvuotajji traukinị sudarė garvežiai, artilerijos platformos, kulkosvaidžių vagonai, drezina, keleiviniai kelių klasių ir prekiniai vagonai, kontrolinès platformos.

Visada šarvuotųjų traukinių kovinę dalị sudarè vokiški prekiniai garvežiai ( $\mathrm{P}_{5}^{4}$ serijos 1905 m. „Henschel“ (Nr. 653), 1906 m. ir 1908 m. „Borsing“ (Nr. 673 ir Nr. 689), 1903 m. „Hanomag“ (Nr. 684) firmų ir $\mathrm{P}_{4}^{3}$ serijos (Nr. 633), keturašès ir dviašès artilerijos platformos, kulkosvaidžių vagonai, šešiavietẻ motorinė ir rankinè šarvuotosios drezinos. Pirmoji drezina buvo gauta $1921 \mathrm{~m}$. spalio $11 \mathrm{~d}$., antroji - $1934 \mathrm{~m}$. balandžio $7 \mathrm{~d} .{ }^{114}$ Bazinę dalị sudarè rusiški ir vokiški keturašiai, triašiai ir dviašiai keleiviniai I-II, III ir IV klasès ir prekiniai vagonai, kontrolinès platformos ${ }^{115}$.

Iš pradžių šie riedmenys buvo skirti tik vienam šarvuotajam traukiniui "Gediminas", tačiau jo pagrindu formuojant kitus šarvuotuosius traukinius visa ši technika, papildyta ir iš geležinkelių dirbtuvių gauta techni-

${ }^{112}$ Isakymas Šarvuočių rinktinei Nr. 223/2, Kaunas, 1935 m. liepos 31 d., ten pat, b. 86, 1. 154-155; Z. Ivinskis, Šarvuočių rinktinès istorija: rinktinès 15-os metų sukakčiai pažymèti nuo 1920.VII.14 iki 1935.VII.14, LNMMB RK RSK, f. 29-737, 1. 11.

${ }^{113}$ V. Statkus, Lietuvos ginkluotos pajegos 1918-1940 m., p. 352.

114 Šarvuotųjų traukinių pulkui įsakymas Nr. 13/6, Kaunas, 1923 m. sausio 20 d., LCVA, f. 828, ap. 1, b. 22, 1. 16; 1923 m. spalio mèn. Lietuvos Respublikos KAM šarvuotujuc traukinių pulko mechaniko vyr. ltn. A. Barotos raštas Geležinkelių valdybos Traukos tarnybos viršininkui, ten pat, b. 23, 1. 57; 19360220 Lietuvos Respublikos KAM Šarvuočių rinktinès žinios apie 1924-1936 m. gautus ir perduotus riedmenis, ten pat, b. 81, 1. 159; 19210630 Lietuvos Respublikos KAM Tiekimų valdybos viršininko mjr. S. Zaskevičiaus pareiškimas krašto apsaugos ministrui, ten pat, f. 1, ap. 1, b. 144, 1. 10.

${ }^{115} 19360220$ Lietuvos Respublikos KAM Šarvuočių rinktinès žinios apie 1924-1936 m. gautus ir perduotus riedmenis, ten pat, f. 828, ap. 1, b. 81, 1. 159. 


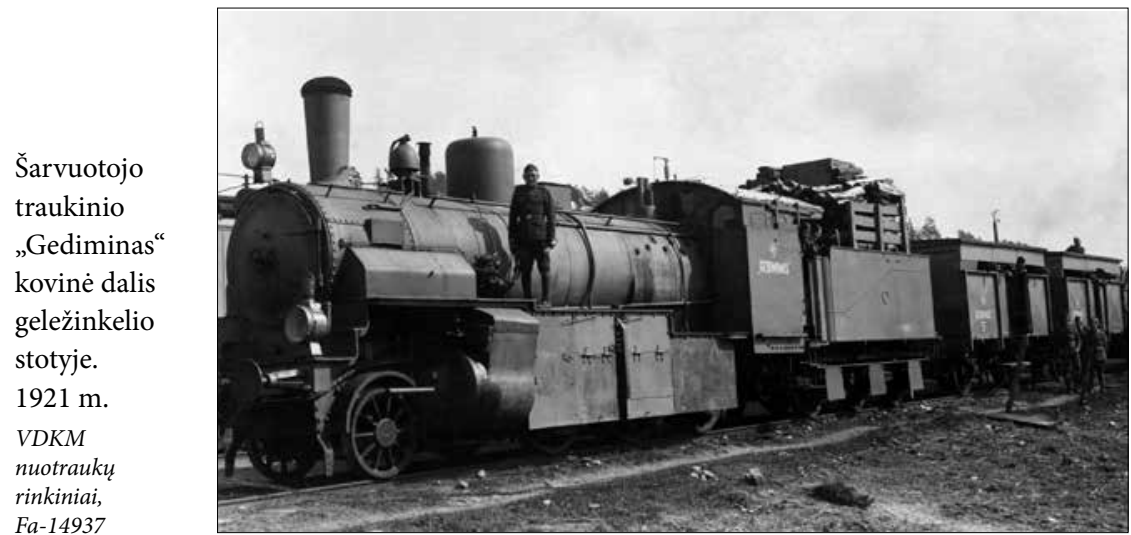

ka, buvo atitinkamai perskirstyta. Pvz., $1921 \mathrm{~m}$. rugpjūčio $1 \mathrm{~d}$. garvežys Nr. 653, artilerijos platforma Nr. 3, kulkosvaidžių vagonas Nr. 5 buvo skirti traukiniui „Gediminas“, artilerijos platforma Nr. 1 ir kulkosvaidžių vagonas Nr. 6 - traukiniui „Kęstutis“, artilerijos platforma Nr. 2 - traukiniui „Algirdas“116. O performuojant ir išformuojant šarvuotuosius traukinius 1926 m. rugpjūčio $28 \mathrm{~d}$. ir rugsèjo $22 \mathrm{~d}$. garvežiai buvo perduoti 2-ajam artilerijos pulkui ir Geležinkelių valdybai, artilerijos platformos, kulkosvaidžių ir keleiviniai III ir IV klasès vagonai - 2-ajam artilerijos pulkui, I-II klasès vagonai, drezinos - $1935 \mathrm{~m}$. rugsèjo $4 \mathrm{~d}$. 2-ajam inžinerijos batalionui. Kita dalis prekinių vagonų ir platformų 1926, 1929, 1930 ir $1935 \mathrm{~m}$. buvo perduotos 2-ajam artilerijos pulkui, 2-ajam inžinerijos batalionui ir Geležinkelių valdybai ${ }^{117}$.

1926 m. rugsèjo 22 d. šarvuotųjų traukinių batalionui priklausė du garvežiai, penkios artilerijos platformos, du kulkosvaidžių vagonai, keturi keleiviniai vagonai, vagonas-elektros stotis, vagonas-virtuvé, devyniolika prekinių gyvenamųjų vagonų ir penki negyvenamieji prekiniai vagonai $^{118}$. Batalione, performuotame $\mathfrak{i}$ kuopą, liko tie patys riedmenys,

${ }^{116}$ Šarvuotų traukinių pulkui įsakymas Nr. 1/5, Kaunas, 1921 m. rugpjūčio 1 d., ten pat, b. 4, 1. 262 ap; 1920-1922 m. Lietuvos Respublikos KAM šarvuotųų traukinių pulko istorinè apžvalga, ten pat, b. 8, 1. 20 ap.

${ }^{117} 19360220$ Lietuvos Respublikos KAM Šarvuočių rinktinės žinios apie 1924-1936 m. gautus ir perduotus riedmenis, ten pat, b. 81, 1. 159.

118 Šarvuočių rinktinei įsakymas Nr. 270/36, Kaunas, 1926 m. rugsèjo 30 d., ten pat, b. 28, 1. 493. 


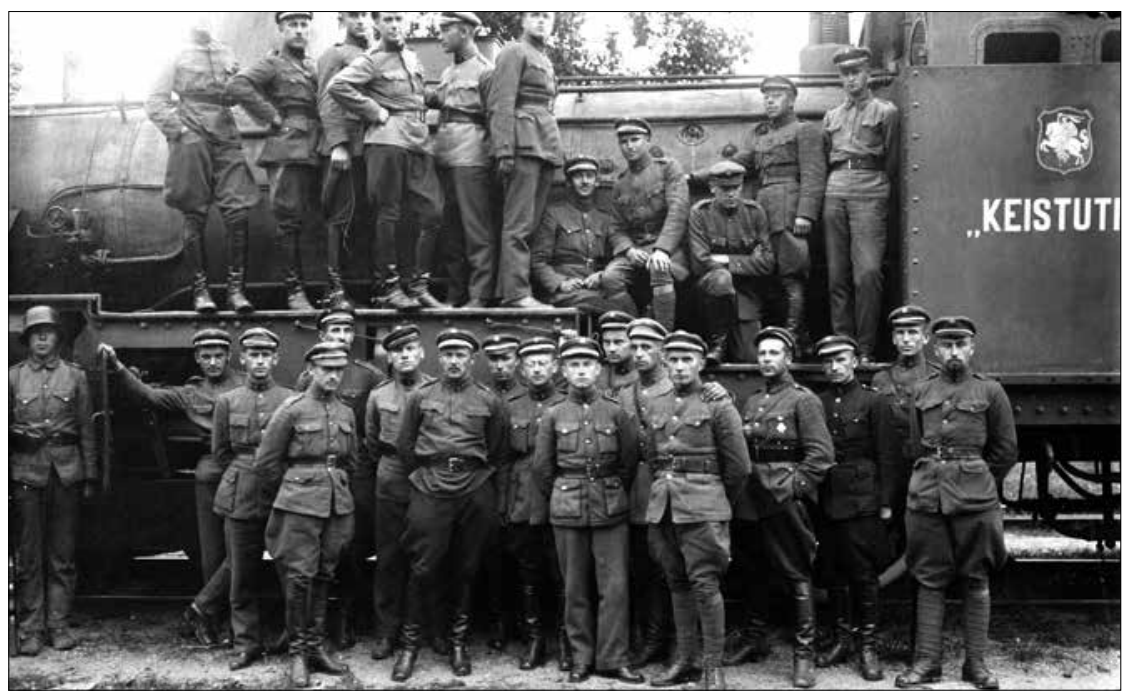

Lietuvos kariuomenès karininkai prie 2-ojo šarvuotojo traukinio „Kęstutis“ garvežio. Apie 1922 m. Apačioje stovi: 5-as - šarvuotojo traukinio „Kęstutis“ kulkosvaidžiu vagono vadas ltn. A. Vilèniškis, 6-as šarvuotojo traukinio „Gediminas“ artilerijos platformos vadas ltn. J. Toliušis, 7-as - kpt. Nikolajus Radionovas VDKM nuotrauku rinkiniai, Fa-14934/39

tik kovinejje dalyje sumažèjo viena artilerijos platforma ${ }^{119}$.

Lietuvos kariuomenès atstovai nuolat ieškojo galimybių ir būdų modernizuoti karo techniką. Todèl, pvz., 1928 m. ketinta įsigyti automotrisą, tačiau išskirtinai karo tikslams firmos automotrisų negamino, nors specialius užsakymus galèjo ir įvykdyti. Buvo domètasi, kaip įsigyti transportui gabenti „Berliet“ (Prancūzija), keleiviams vežti „Fiat“ (Italija) ir „Tatra“ (Čekoslovakija) firmų geležinkelio technikos ${ }^{120}$.

Taikos metu šarvuotasis traukinys „Gediminas“ buvo ginkluotas $275 \mathrm{~mm} 1916 \mathrm{~m}$. modelio (Prancūzija) ir $257 \mathrm{~mm}$ (Vokietija / Anglija?) patrankomis ir 4 7,92 mm $1908 \mathrm{~m}$. modelio „Maxim 08“ kulkosvaidžiais (Vokietija). Šarvuotajame traukinyje „Kęstutis“ buvo įrengtos $277 \mathrm{~mm}$ 1896 m. / 1916 m. (Vokietija) patrankos ir 4 7,92 mm 1908 m. mode-

\footnotetext{
119 Šarvuočių rinktinei įsakymas Nr. 290/5, Kaunas, 1927 m. spalio 11 d., ten pat, b. 30, 1. 349 ap.

${ }^{120} 19281118$ Lietuvos Respublikos KAM komisijos karinei technikai pirkti aktas, ten pat, b. 44, 1. 9 ap.
} 


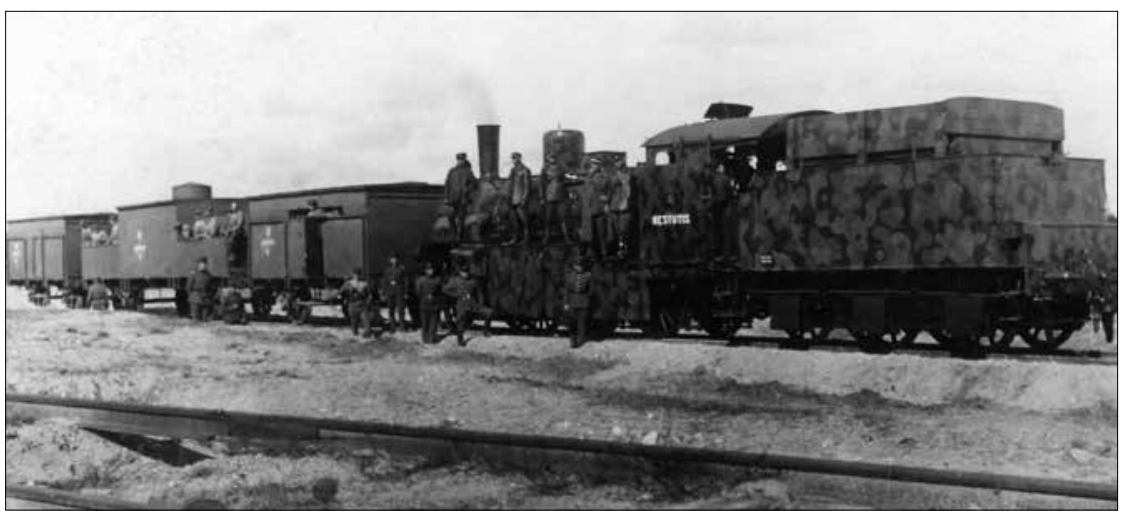

Šarvuotojo traukinio „Gediminas“ garvežys „Kęstutis“. 1930 m. rugsèjo 25 d.

VDKM nuotrauku rinkiniai, neinventorinta

lio „Maxim 08“ kulkosvaidžiai, o šarvuotajame traukinyje „Algirdas“ $2105 \mathrm{~mm} 1898 \mathrm{~m}$. / $1909 \mathrm{~m}$. modelio haubicos (Vokietija) ir 2 7,92 mm 1908 m. modelio „Maxim 08“ kulkosvaidžiai ${ }^{121}$. Tiesa, ant šarvuotojo traukinio artilerijos platformos (viduryje) buvo šarvuota keturkampé vadavietė su keturiomis angomis kulkosvaidžiams šaudyti, bet to neužteko - traukinyje turèjo būti mažiausiai vienas kulkosvaidžių vagonas bent su 14 kulkosvaidžių: 2 - bokštelyje ant stogo, 4 - vagono kampuose (sukami), 8 - iš šonų (po 4), o ant platformos papildomai - bent po 2 kulkosvaidžius bokšteliuose ${ }^{122}$.

1921 m. rugsejjo-1922 m. kovo mèn. geležinkelių ir artilerijos dirbtuvèse buvo apšarvuoti du garvežiai, kovinèje dalyje - artilerijos platformos su $75 \mathrm{~mm}$ prancūzų ir $57 \mathrm{~mm}$ vokiečių (anglų) gamybos patrankomis, jose esančiuose bokšteliuose buvo įrengtos vietos kulkosvaidžiams, o bazinèje dalyje - I klasės keleiviniai ir 8 prekiniai vagonai ${ }^{123}$.

${ }^{121} 1920-1922$ m. Lietuvos Respublikos KAM šarvuotųjų traukinių pulko istorinè apžvalga, ten pat, b. 8, 1. 20 ap.-21; A. Pociūnas, Šarvuoti traukiniai Lietuvos kariuomenèje, Karys, p. 23; 19230810 Lietuvos Respublikos KAM Artilerijos viršininko valdybos pareiškimas, $L C V A$, f. 1373, ap. 1, b. 128, 1. 195-195 ap.

${ }^{122}$ А. В. Шавровъ, Бронепоздюзда. Значеніе, вооруженіе, организація и тактика бронепоздпздовъ, с. 15.

${ }^{123}$ 1920-1922 m. Lietuvos Respublikos KAM šarvuotųjų traukinių pulko istorinė apžvalga, $L C V A$, f. 828 , ap. 1, b. 8, 1. 21-21 ap. 

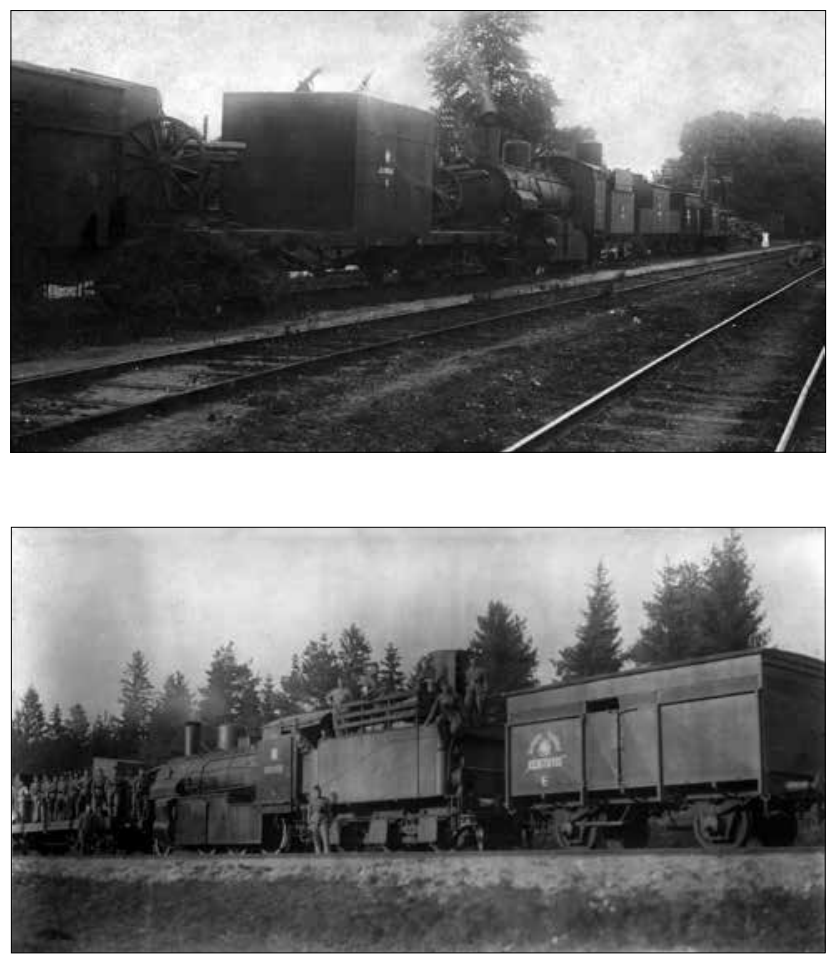

Šarvuotieji

traukiniai

„Algirdas“ir

„Kęstutis“ stovi ant atsarginių bejgių savo dislokacijos vietoje. Žemoji Freda, Kaunas, 1921-1923 m. Edvardo Vasiliausko asmenine kolekcija

Šarvuotojo traukinio „Kęstutis“ igula prie traukinio tarnybos metu. 1921-1923 m.

LCVA Fs, P-19425

1923 m. rugpjūčio $10 \mathrm{~d}$. žiniomis, šarvuotųjų traukinių pulkas turejjo net 8 iqvairių kalibrų $(75 \mathrm{~mm}, 76,2 \mathrm{~mm}, 77 \mathrm{~mm}$ ir $105 \mathrm{~mm})$ pabūklus ${ }^{124}$. Tačiau realių duomenų apie $76,2 \mathrm{~mm}$ patrankas, naudotas traukiniuose, aptikti nepavyko, o ir turimoje gausioje ikonografineje medžiagoje jų tiesiog nematyti. 1923-1924 m. sandūroje ị šarvuotųjų traukinių ginkluotę buvo ịtrauktos vokiškos (angliškos) $57 \mathrm{~mm}$ patrankos. Šie pabūklai šarvuotųjų traukinių ginkluotėje išliko iki XX a. 4-ojo dešimtmečio vidurio. Teiktinas 1934 m. pavyzdys, kai šarvuotojo traukinio keturiose artilerijos platformose buvo po dvi $57 \mathrm{~mm}$ kaponierių ir $77 \mathrm{~mm}$ patrankas ir viena 105 mm haubica, dviejuose kulkosvaidžių vagonuose - 251908 m. modelio „Maxim 08“ kulkosvaidžiai. O bazinę dali sudarè keleiviniai vagonai (po vieną I-II, III ir IV klasès), skirti karininkams, kareiviams apgyven-

12419230810 Lietuvos Respublikos KAM Artilerijos viršininko valdybos pareiškimas, ten pat, f. 1373,ap. 1, b. 128, 1. 195-195 ap. 


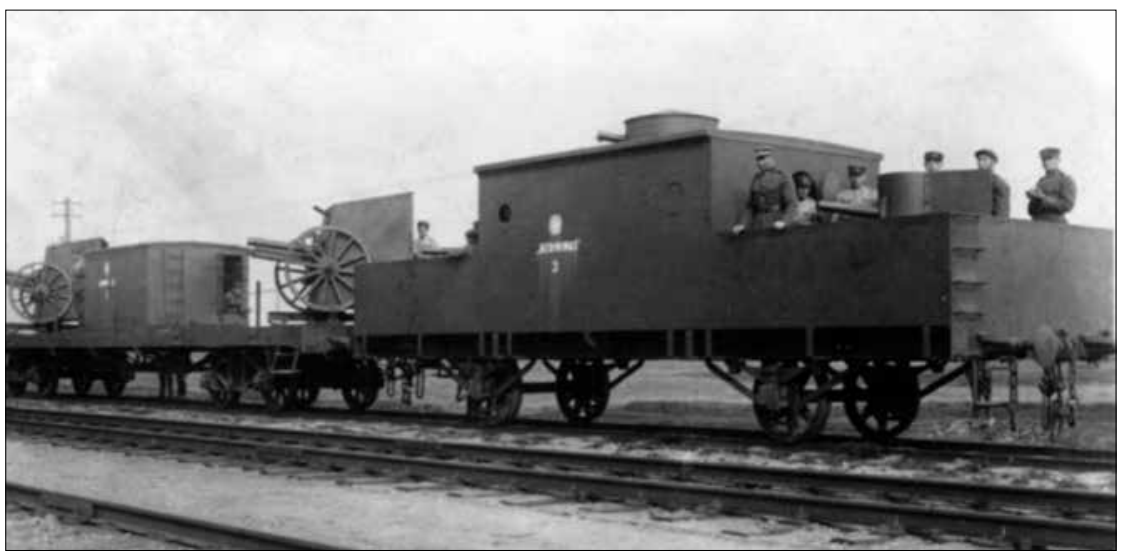

Šarvuotojo traukinio „Gediminas“ igula ant artilerijos platformų prie $75 \mathrm{~mm} 1916 \mathrm{~m}$. modelio (Prancūzija) ir dviejų $57 \mathrm{~mm}$ (Vokietija) patrankų. 1923-1931 m.

Ruslano Kirejevo asmeniné kolekcija

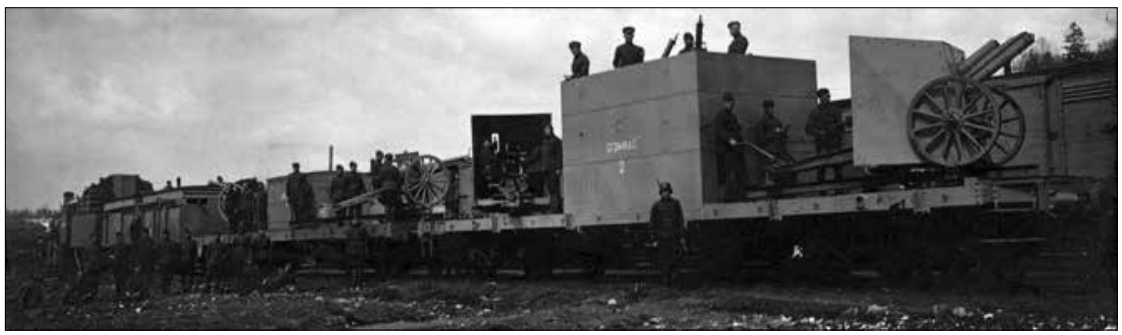

Šarvuotojo traukinio „Gediminas“ igula lauko pratybose. 1922 m. LCVA Fs, P-20191

dinti, sargybos būstinei, štabui, klasèms įrengti, aštuoni prekiniai vagonai artilerijos, technikos inventoriui, kurui (malkoms) laikyti, maisto sandèliui, virtuvei, elektros stočiai įrengti ir dvi kontrolinès platformos ${ }^{125}$.

Šarvuotieji traukiniai buvo nudažyti slepiamąja spalva netaisyklingų formų dèmèmis, atskiroms užduotims vykdyti buvo maskuojami paran-

${ }^{125} 1934 \mathrm{~m}$. gegužès mèn. Lietuvos Respublikos KAM Šarvuočių rinktinès vado mjr. A. Zubavičiaus raportas Šarvuočių rinktinès vadui, ten pat, f. 828, ap. 1, b. 78, 1. 12; 19341121 Lietuvos Respublikos KAM einančio Karo technikos štabo viršininko pareigas plk. ltn. P. Kutkos atsakymas i paklausimą Vyriausiojo štabo valdybos II skyriaus viršininkui, ten pat, f. 1364, ap. 1, b. 177, 1. 258. 
kinėmis priemonėmis ${ }^{126}$. Ant traukinio garvežio ir vagonų šonų buvo ta pati simbolika - Vytis raudoname fone, traukinio pavadinimas ir vagonu numeriai. Šarvuotieji traukiniai buvo ginkluoti ịvairių kalibrų artilerijos pabūklais (gamintojai Prancūzija ir Vokietija), kulkosvaidžiais (gamintoja Vokietija), ju igulos karininkai - 7,65 mm „Mauser“ (Vokietija) ir „Retolaza“ (Ispanija) pistoletais, kardais, puskarininkiai - $9 \mathrm{~mm}$ „Parabellum“ (Vokietija) pistoletais, kareiviai - lengvaisiais pėstininkų šaunamaisiais ginklais - 7,92 mm 1888 m., 1898 m. modelio „Mauser“ (Vokietija) šautuvais ir karabinais, 7,71 mm 1914 m. modelio „Lee Enfield“ (Didžioji Britanija) šautuvais ir granatomis.

Kariai dèvejo lietuviškas karines uniformas su išskirtiniais skiriamaisiais ženklais. Nuo 1923 m. tik šarvuotųjų traukinių dalinio kariai nešiojo
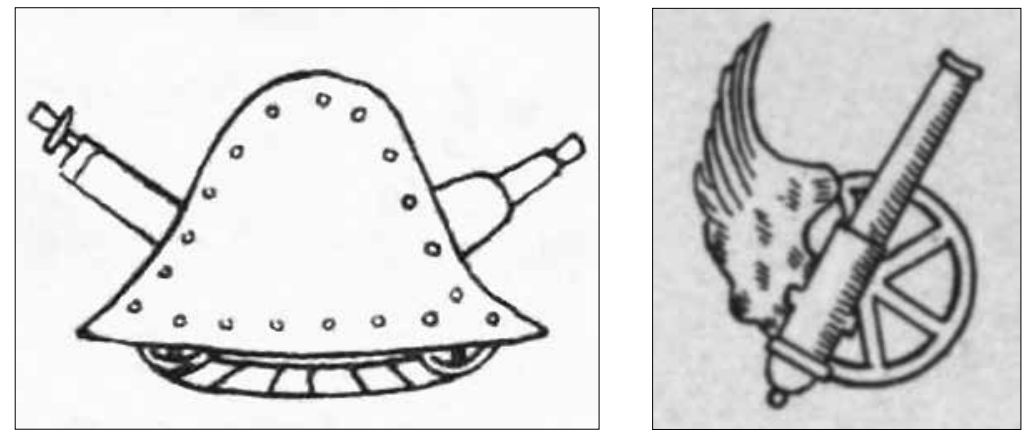

1923 ir 1931 m. modelio šarvuotininkų antpetiniai ženklai

Isakymas kariuomenei Nr. 53/1, Kaunas, 1923 m. kovo 27 d.; Isakymas kariuomenei Nr. 6/1, Kaunas, 1931 m. sausio $28 d$.

antpetinị ženklą, kuriame buvo pavaizduotas ratas, pabūklas ir sparnai, o nuo 1931 m. - bendrąji šarvuotininkų ženklą, kuriame buvo pavaizduotas vikšras, pabūklo ir kulkosvaidžio vamzdžiai.

Karių tarnyba traukinių dalinyje vyko organizuotai, mokant siekta suteikti reikalingų karybos žinių ir igūdžių ir juos įtvirtinti. Kariai dalinyje išeidavo teorinị ir praktinị kursą. Jie mokèsi lietuvių kalbos, istorijos,

${ }^{126}$ А. В. Шавровъ, Бронепоздпзда. Значеніе, вооруженіе, организація и тактика бронепоздпздовъ, с. 19. 
Lietuvos kariuomenės šarvuotieji traukiniai 1920-1935 m.

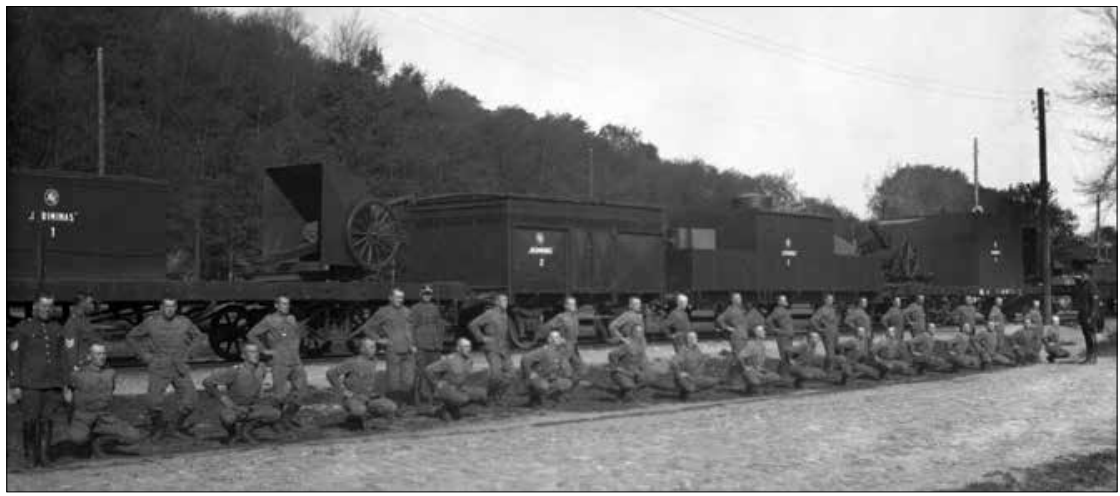

Šarvuotojo traukinio „Gediminas“ igula atlieka mankštos pratimus. 1923-1931 m. LNMMB RKRs Z. Ivinskio kolekcija, F-29-761/28

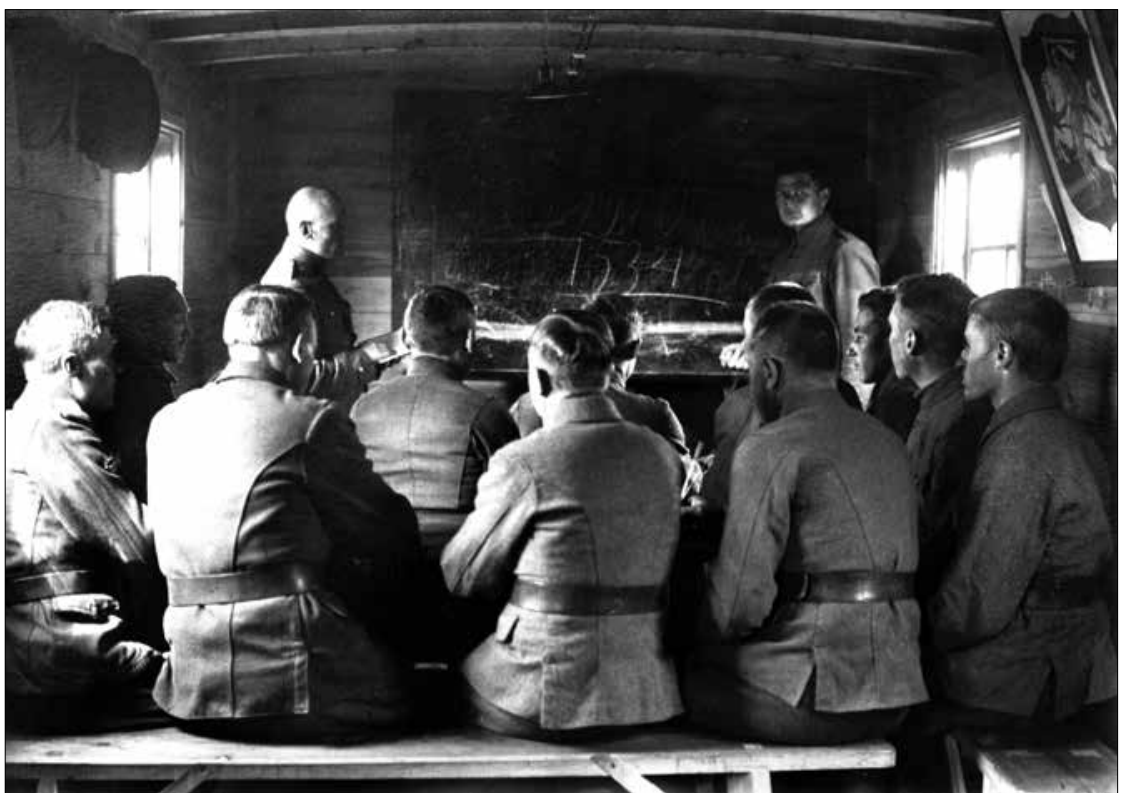

Šarvuotojo traukinio „Gediminas“ igulos kariai klausinèjami artilerijos platformos vado ltn. J. Toliušio teorinių mokymų metu. Apie 1922 m.

VDKM nuotrauku rinkiniai, Fa-14934/4 


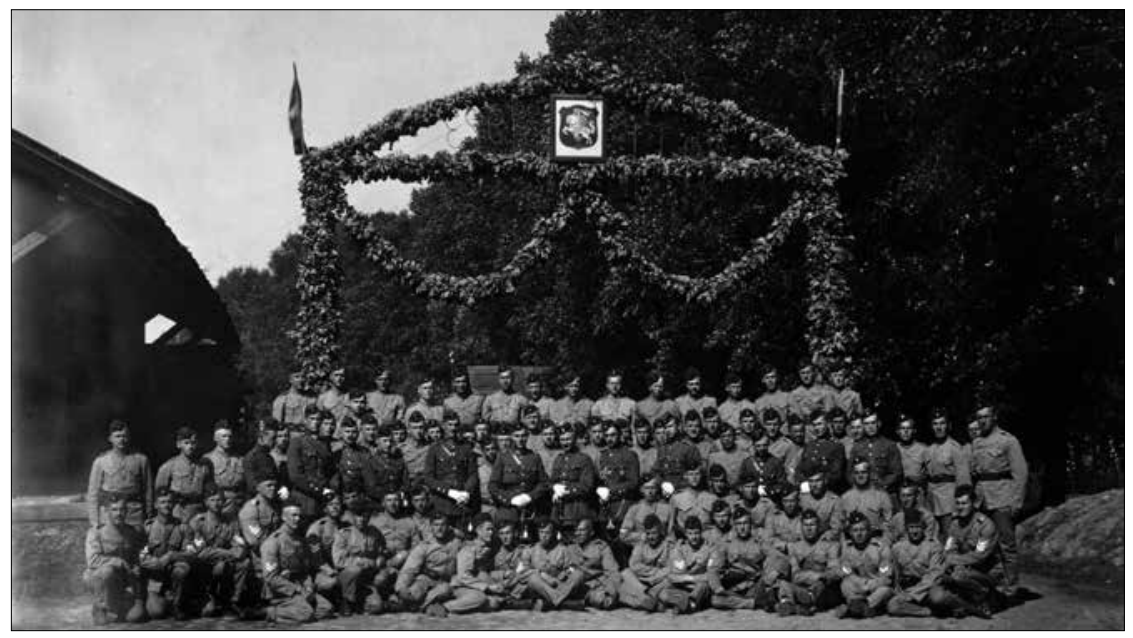

Šarvuotụjų traukinių vadovybė ir šarvuotojo traukinio „Gediminas“ kariai per iškilmes pozuoja bendrai nuotraukai. Apie 1923 m. VDKM nuotrauku rinkiniai, Fa-14943

politologijos, geografijos, matematikos, fizikos, geometrijos, karinių statutų, tikybos, rikiuotès, šarvuočių taktikos (ginantis, puolant, stabdant), ryšių organizavimo, karo inžinerijos ir karo topografijos, ginkluotès (artilerijos pabūklų, kulkosvaidžių, šautuvų, karabinų, pistoletų, granatų) pagrindų ir šaudybos, geležinkelio pažinimo, traukinio priežiūros dalykų, gimnastikos, higienos. Taip pat buvo komandiruojami tobulintis ị kitas krašto apsaugos ir susisiekimo žinybos įstaigas, jų rengiamus kursus, pvz., ì pėstininkų, artilerijos pulką, ryšių batalioną, geležinkelių kuopą. Mokant buvo naudojama ịvairi literatūra, brèžiniai ir kovos technika.

Laisvu nuo tarnybinių užduočių laiku kariai mokèsi, skaitė karinę literatūrą, sportavo, ilsèjosi karių ramovèje, klube ${ }^{127}$. Beje, Šarvuočių rinktinè nuo 1925 m. rugpjūčio 25 d., t. y. minint šarvuotojo traukinio „Gediminas" suformavimo datą, o nuo 1927 m. - liepos 14 d., minint pirmąji šarvuotų automobilių susidūrimo su lenkais Nepriklausomybès kovų metu atveji, švęsdavo savo šventę. Ji galiausiai 1929 m. rugsèjo 12-ąją tapo bendra visų kariuomenès technikos dalių švente ${ }^{128}$.

${ }^{127}$ Isakymas kariuomenei Nr. 102/1, Kaunas, 1922 m. balandžio 25 d.

${ }^{128}$ Karo technikos dalių dvidešimtmetis 1919-1939, Kaunas, 1939, p. 202, 368. 


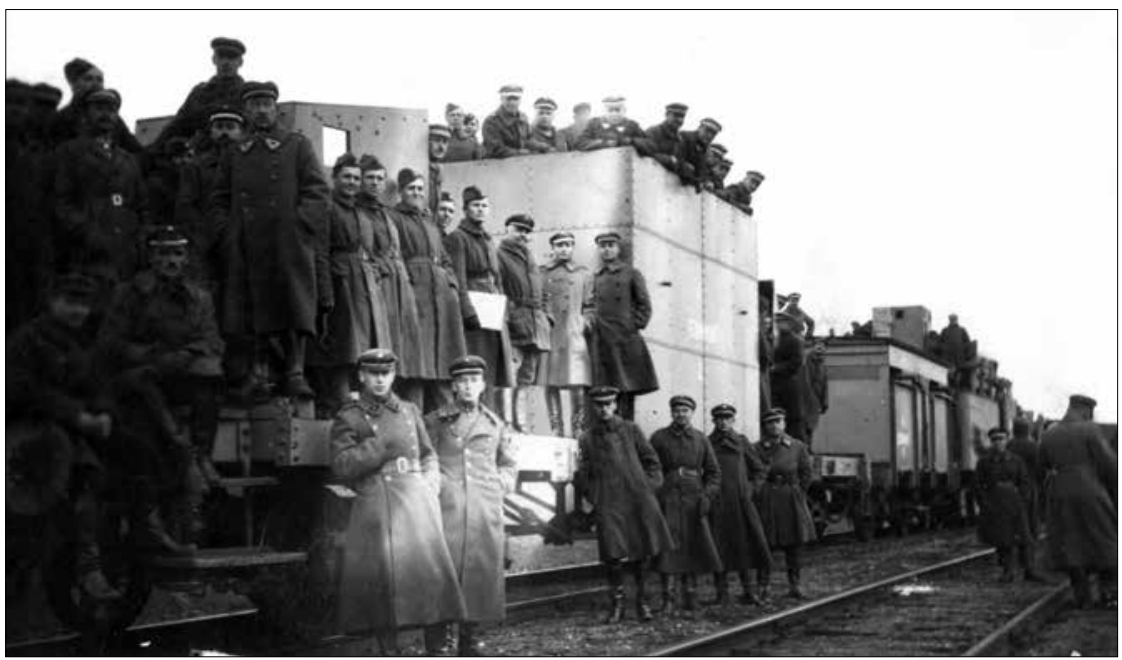

Lietuvos karinè vadovybė ir Aukštųjų karininkų kursų klausytojai ant šarvuotojo traukinio „Gediminas" kontrolinių platformų su karinių sandèlių turtu prieš vykstant ị Žemaičių rinktinès manevrus. $1922 \mathrm{~m}$. rugsèjis. R. Kirejevo asmeninè kolekcija

Tenka pridurti, kad kariuomenès šarvuotosios technikos riedmenys buvo nepakankamai eksploatuojami, nes jų rida sudarè ne kelis šimtus tūkstančių, o vos kelias dešimtis tūkstančių kilometrų ${ }^{129}$. Tai lèmé jų funkcijos ir uždaviniai, materialinis aprūpinimas ir techninès galimybès. Pvz., traukiniai dalyvaudavo manevruose, pratybose ir mokymuose Varénos ir Gaižiūnų poligonuose, atlikdavo žvalgybą, tačiau jų veikimo teritorija dažniausiai apimdavo Kauno ir Radviliškio apylinkes, rečiau tolimesnes vietas: Tauragę, Šiaulius, Mažeikius ar Klaipèdą. Traukiniai buvo kuriami kietuoju kuru - malkomis ir anglimis, jų vidutinis greitis siekè 30-45 km/h, didžiausias - $65 \mathrm{~km} / \mathrm{h}$.

Lietuvos kariuomenès šarvuotieji traukiniai buvo naudojami žvalgybos, priedangos ir paramos funkcijoms atlikti, strateginiams ir kariniams objektams saugoti, taip pat mobilizacijos metu.

Šarvuotojo traukinio privalumai buvo šie: moralinis aspektas (galè-

12919341206 Lietuvos Respublikos KAM šarvuotųjų traukinių kuopos mjr. A. Zubavičiaus raštas rinktinès Ūkio skyriaus viršininkui, $L C V A$, f. 1364, ap. 1, b. 409, 1. 3. 


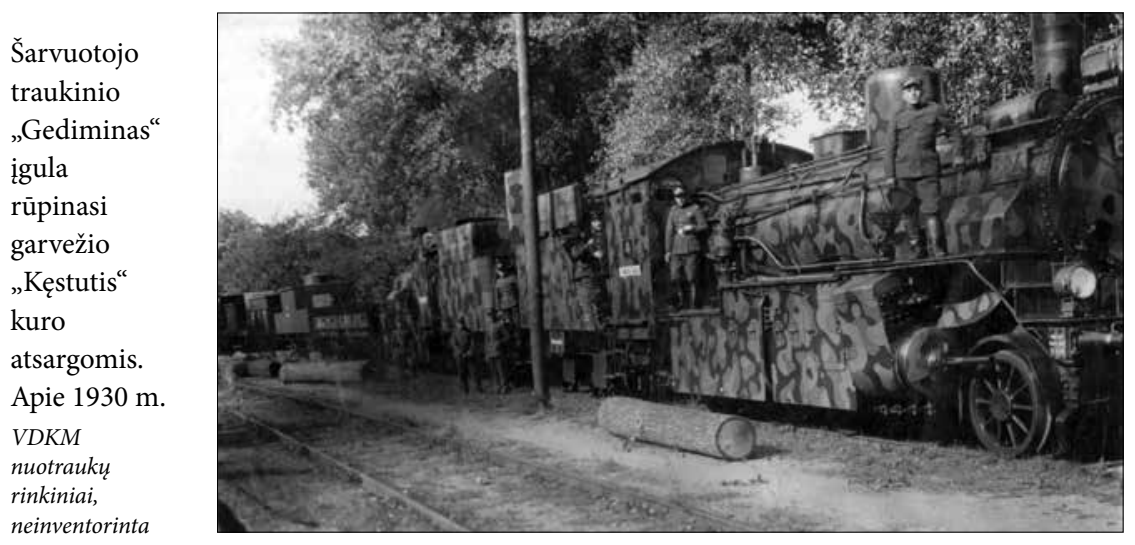

jo priešą priversti trauktis, pasiduoti panikai), ugnies galia (lengvoji ir sunkioji artilerija, kulkosvaidžiai), manevringumas (gana didelis greitis, netikètumo veiksnys), nesudetingas techninis valdymas. Tačiau šarvuotojo traukinio eksploatacija (pagaminimas, suformavimas, išlaikymas ir apginklavimas) atsiëjo gana brangiai (vien garvežio remontas galejjo kainuoti iki 30 tūkst. Lt) ${ }^{130}$, naudojimo galimybès priklausè nuo geležinkelių tinklo (galejjo veikti tik tam tikrame jo ruože), jo veiksmai naktị ir žiemą buvo riboti (netiko efektyviems veiksmams vykdyti tamsiu paros metu, o šaltuoju metų laiku traukinys galejo pradèti veikti tik po 3-6 val.) ${ }^{131}$. Traukinys buvo iš dalies šarvuotas, o jo šaudymo sektorius - ribotas (patrankų šaudymo sektorius siekė 90, kulkosvaidžių - 180 laipsnių, ne visada iš karto buvo galima šaudyti iš dviejų pabūklų), sudètinga komplektacija, sunku palaikyti ryši (kariai bendraudavo naudodamiesi ruporu, sutartiniais ženklais, telefonu) ${ }^{132}$. Dèl viso to šarvuotųjų traukinių ir buvo atsisakyta.

\footnotetext{
${ }^{130} 19350102$ Lietuvos Respublikos KAM Vytauto Didžiojo aukštųjų karininkų kursų Mechanikos ir vidaus degimo variklių kabineto vedejjo inž. M. Piskorskio raportas Karo technikos valdybos viršininkui, LCVA, f. 1364, ap. 1, b. 409, 1. 1.

${ }^{131}$ Instrukcija šarvuotiems traukiniams, p. 6-7; 19340604 Lietuvos Respublikos KAM Šarvuočių rinktinès vado gen. št. plk. ltn. A. Šovos raportas karo technikos viršininkui, LCVA, f. 828, ap. 1, b. 78, 1. 32.

132 А. В. Шавровъ, Бронепоздъзда. Значеніе, вооруженіе, организація и тактика бронепоздъздовъ, с. 5.
} 


\section{ESTIJOS IR LATVIJOS KARIUOMENIŲ ŠARVUOTIEJI TRAUKINIAI 1919-1940 M.}

1919-1940 m. visų Baltijos valstybių (Estijos, Latvijos ir Lietuvos) kariuomenès turèjo šarvuotųjų traukinių. Ypač svarbų vaidmenị jie suvaidino Nepriklausomybès kovų metu. Skirtingai nuo Lietuvos, Estijos ir Latvijos kariuomenès šarvuotụjų traukinių atsisakyti neskubejjo, jų daliniai buvo ne kartą performuoti, netgi modernizuoti, o galimos funkcijos ir užduotys perskirstytos atsižvelgian $\mathfrak{i}$ kariuomenès poreikius ir galimybes.

Estijos kariuomenès šarvuotieji traukiniai Nepriklausomybès kovų (1919-1920 m.) laikotarpiu ${ }^{133}$ suvaidino ypatingą vaidmenị ir patyrè daug nuostolių ${ }^{134}$. Iš viso Estijos kariuomenè turejjo šešis plačiajam ir penkis

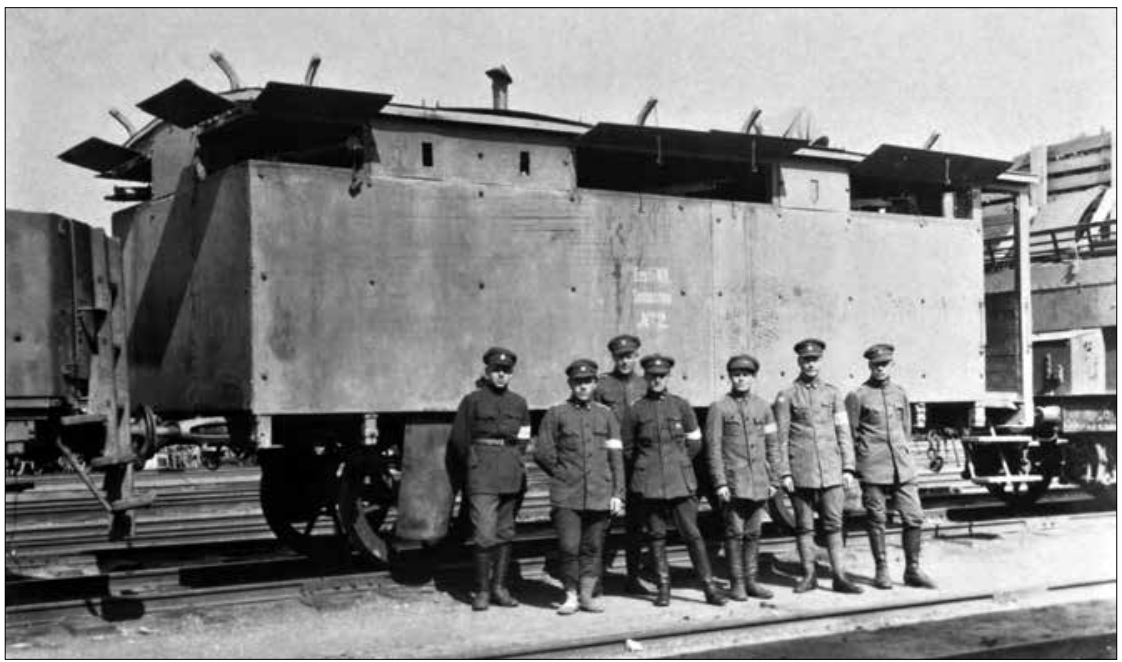

Estijos kariuomenès plačiųjų geležinkelių šarvuotojo traukinio Nr. 2 igula prie kulkosvaidžių vagono, ginkluoto 7,92 mm „Maxim MG08“ modelio sunkiaisiais kulkosvaidžiais (Vokietija). Estija, 1919 m. gegužè

Estijos karo muziejaus - Generolo Laidonerio muziejaus (toliau - EKM GLM) rinkiniai, inv. Nr. KLMF 11005-036

${ }^{133}$ J. Soots, Estų Nepriklausomybès karai, Mūsų žinynas, 1931, t. XX, Nr. 73, 1. 276.

${ }^{134}$ H. Walter, Soomusrongid, Laidoneri Muuseumi Aastaraamat, Tallinn, 2002, Nr. 1, 1. 17-27; T. Tojak, Vabadussõjas langenud soomusronglased, ten pat, 1. 28-37. 


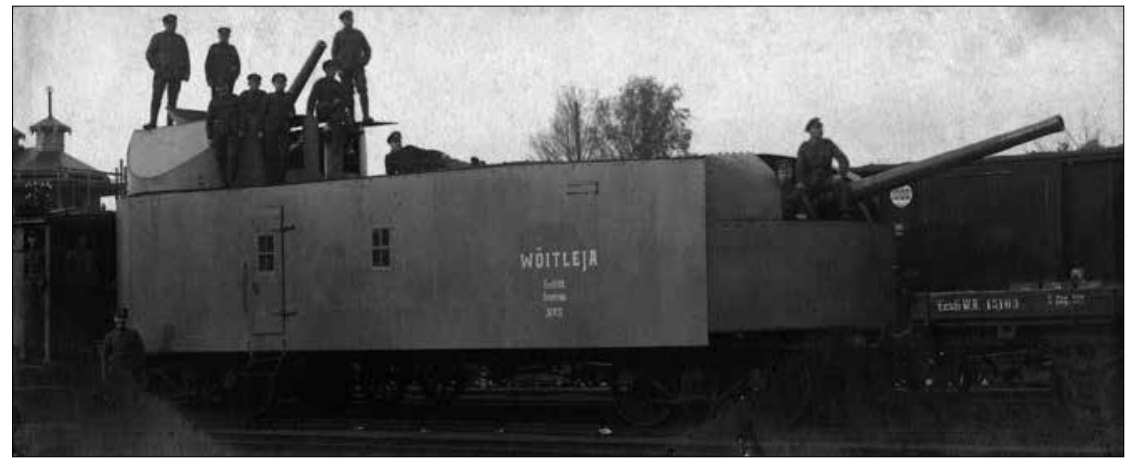

Estijos kariuomenės plačiųjų geležinkelių šarvuotojo traukinio Nr. 5 artilerijos vagono „Wõitleja“ („Karžygys“) igula prie $120 \mathrm{~mm}$ haubicos ir $75 \mathrm{~mm}$ patrankos. Estija, $1919 \mathrm{~m}$. ruduo EKM GLM rinkiniai, inv. Nr. KLMF1106-036

siaurajam geležinkelių ruožams pritaikytus šarvuotuosius traukinius. Visi plačiųjų geležinkelių šarvuotieji traukiniai turèjo numerius, išskyrus šarvuotąji traukinị Nr. 1, kuris buvo gavęs pavadinimą, kaip artilerijos ir kulkosvaidžių vagonai.

Šarvuotajji traukinị Nr. 1 „Kapten Jrw“ („Kapitonas Irvis“) sudarè du artilerijos vagonai - „Pisuhänd“ („Vabalas“) ir „Wambola“ („Vambola“). Pirmasis buvo ginkluotas $276 \mathrm{~mm}$ patrankomis, antrasis - $107 \mathrm{~mm}$ patranka (Vokietija), juose dar buvo sumontuoti 22 kulkosvaidžiai. Šarvuotajame traukinyje Nr. 2 buvo trys artilerijos vagonai - „Uku“ („Perkūnas“), ginkluotas $76 \mathrm{~mm}$ patranka ir $122 \mathrm{~mm}$ haubica, „Kalew“ („Kalevas“), ginkluotas $76 \mathrm{~mm}$ paranka, ir „Sepp Willu“ („Kalvis Vilu“), ginkluotas $76 \mathrm{~mm}$ patranka ir $122 \mathrm{~mm}$ haubica. Be haubicų ir patrankų, juose dar buvo 23 kulkosvaidžiai.

Šarvuotąji traukinị Nr. 3 sudarè du artilerijos vagonai - „Onu Tom“ („Dèdè Tomas") ir „Tont“ („Girinis“ / „Vaiduoklis“). Be 20 kulkosvaidžių, pirmajame vagone buvo įtaisytos $76 \mathrm{~mm}$ ir $75 \mathrm{~mm}$, antrajame - $76 \mathrm{~mm}$ patrankos.

Šarvuotaji traukini Nr. 4 sudarè trys artilerijos vagonai - „Pikker“ („Griaustinis“), „Kõu“ („Perkūnas“) ir „Tõll“ („Telis“). Kaip ir kituose traukiniuose, juose buvo 20 kulkosvaidžių ir artilerijos pabūklų. Pirmajame vagone buvo $122 \mathrm{~mm}$ haubica ir $75 \mathrm{~mm}$ patranka, antrajame - $105 \mathrm{~mm}$ M1916 modelio (Vokietija) haubica, trečiajame - $276 \mathrm{~mm}$ patrankos. 


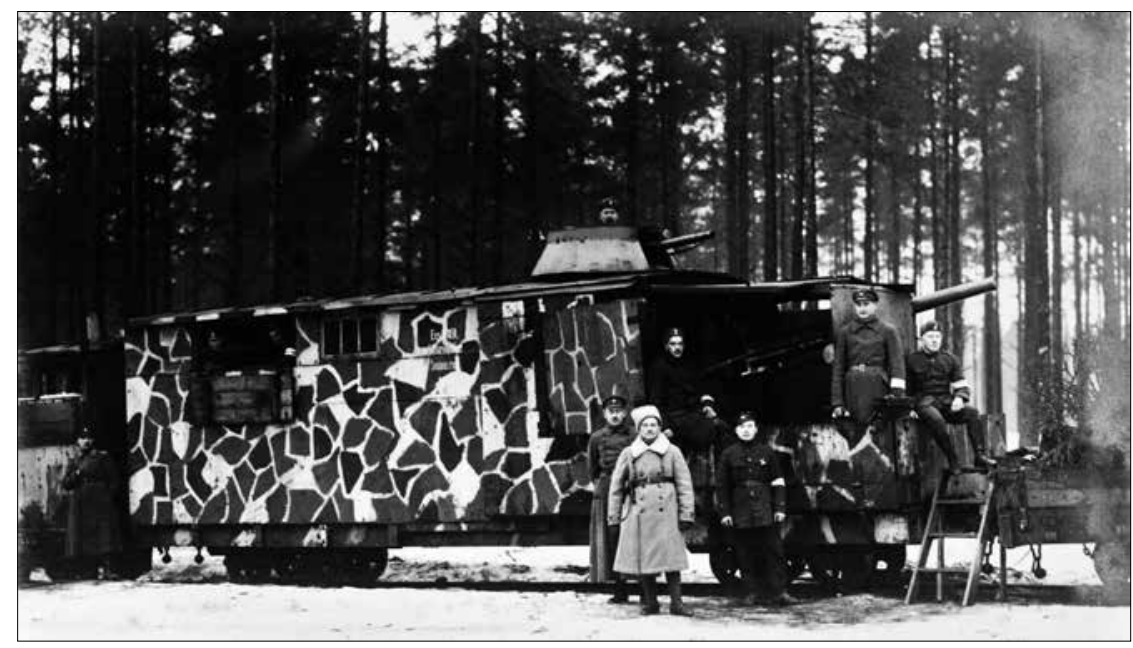

Estijos kariuomenès siaurųjų geležinkelių šarvuotojo traukinio Nr. 5 artilerijos vagono ịgula prie $76 \mathrm{~mm}$ patrankos ir „Lewis“ kulkosvaidžių (Didžioji Britanija). Estija, 1920 m. kovas EKM GLM rinkiniai, inv. Nr. KLMF 11005-103

Šarvuotojo traukinio Nr. 5 sąstatą sudarè du artilerijos vagonai „Wõitleja“ („Karžygys“) ir „Tasuja“ („Keršytojas“). Juose buvo 18 kulkosvaidžių, viename - $120 \mathrm{~mm}$ „Canet“ (Rusija) haubica, $75 \mathrm{~mm}$ ir $84 \mathrm{~mm}$ M1904 modelio (Didžioji Britanija) ir $76 \mathrm{~mm}$ patrankų.

Šarvuotajj traukinị Nr. 6 sudarė trys artilerijos vagonai - „Tommi“ („Tomas“), „Rummu Jüri“ („Jurijus Rumo“) ir „Leitnant Sabolotnõi Kartetsch („Leitenantas Sabolotnis“). Pirmajame buvo pastatytos $57 \mathrm{~mm}$ (Vokietija / Anglija?), antrajame - $76 \mathrm{~mm}$ patrankos, trečiajame - $120 \mathrm{~mm}$ "Canet“ (Rusija) ir $107 \mathrm{~mm}$ haubicos, be to, traukinys buvo ginkluotas 12 kulkosvaidžių ${ }^{135}$.

Penki siaurųjų geležinkelių šarvuotieji traukiniai taip pat buvo numeruoti (išskyrus Nr. 1 „Heinaste“). Jie buvo ginkluoti patrankomis ir kulkosvaidžiais: šarvuotojo traukinio Nr. 1 ginkluotę sudare 2 patrankos ir 12 kulkosvaidžių, Nr. 2 - patranka ir 9 kulkosvaidžiai, Nr. 3 - 2 patrankos ir 9 kulkosvaidžiai, Nr. 4 - patranka ir 6 kulkosvaidžiai, Nr. 5 -

${ }^{135}$ M. Õun, T. Noormets, J. Pihlak, Eesti soomusrongid ja soomusronglased 1918-1941, Tallinn, 2003, 1. 18. 

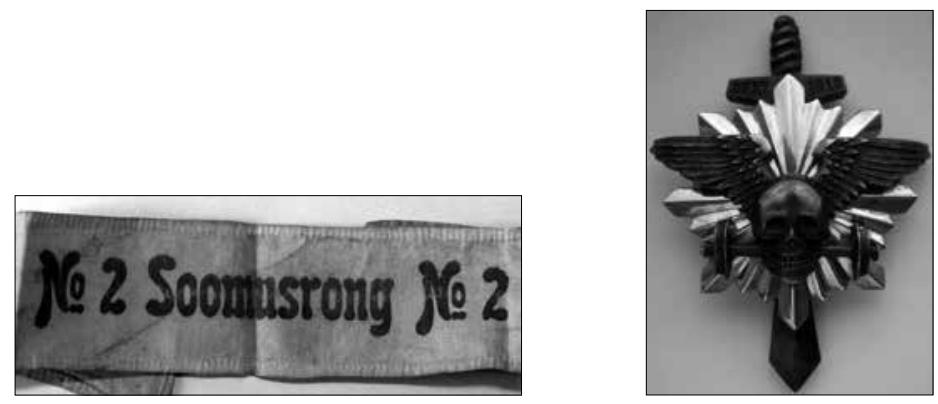

Estijos kariuomenės šarvuotụjų traukinių karių skiriamieji ženklai - raištis ir antkrūtinis ženklas. Pirmasis ryšètas nuo 1918 m. iki XX a. 3-iojo dešimtmečio, antrasis segètas nuo $1934 \mathrm{~m}$. Autoriaus asmenine skaitmeniné kolekcija

patranka ir 4 kulkosvaidžiai ${ }^{136}$. Ilgainiui šarvuotųjų traukinių dalys, jų sudètis (artilerijos ir kulkosvaidžių vagonai ir platformos), karių skaičius ir ginkluotè kito ${ }^{137}$.

1919-1921 m. visi Estijos kariuomenès šarvuotieji traukiniai buvo ịtraukti ị šarvuotụjų traukinių divizioną, o 1921-1923 m. šarvuotųjų traukinių dalinys veike kaip šarvuotụjų traukinių brigada (ji buvo dislokuota Valge). Tačiau $1923 \mathrm{~m}$. jau buvo suformuoti du šarvuotujuc traukinių pulkai - Tapoje ir Valge, nuo 1934 m. - tik Tapoje. Turimais duomenimis, iki 1940 m. šarvuotųjų traukinių pulką sudarè štabas, du šarvuotieji traukiniai - vienas lengvasis ir vienas sunkusis, sunkiųjų kulkosvaidžių, pėstininkų ir technikos kuopos. Lengvieji šarvuotieji traukiniai buvo ginkluoti $276 \mathrm{~mm}$ patrankomis, 8 sunkiaisiais ir 6 priešlekktuviniais sunkiaisiais kulkosvaidžiais, sunkieji - 5 (1 - $152 \mathrm{~mm}, 2$ - $112 \mathrm{~mm}$ ir $2-105 \mathrm{~mm}$ ) haubicomis ir 4 sunkiaisiais kulkosvaidžiais ${ }^{138}$.

\footnotetext{
${ }^{136}$ Straipsnio autoriui nežinomi patrankų kalibrai ir pavadinimai. E. Andersons, The Military Situation in the Baltic States, Baltic Defence Review, 2001, vol. 2, no. 6, p. 123, 136-138; Estonian Army. 21 October 1919, <http://pygmy-wars.50megs.com/technical/ orbats/estonianarmy.html> [žiūrèta: 20150109 ]; Võidukad soomusronglased taastasid eestlaste eneseusu, <http://www.postimees.ee/1746525/voidukad-soomusronglased-taastasid-eestlaste-eneseusu> [žiūrèta: 20150108 ].

137 T. Nõmm, Eesti suurtükivägi 1918-1940. Relvastus ja ülesehitus, Laidoneri Muuseumi Aastaraamat, Tallinn, 2004, Nr. 4, 1. 177-186.

${ }^{138} 19390701$ Estijos Respublikos kariuomenès žinios, LCVA, f. 929, ap. 2, b. 1063, 1. 9
} 


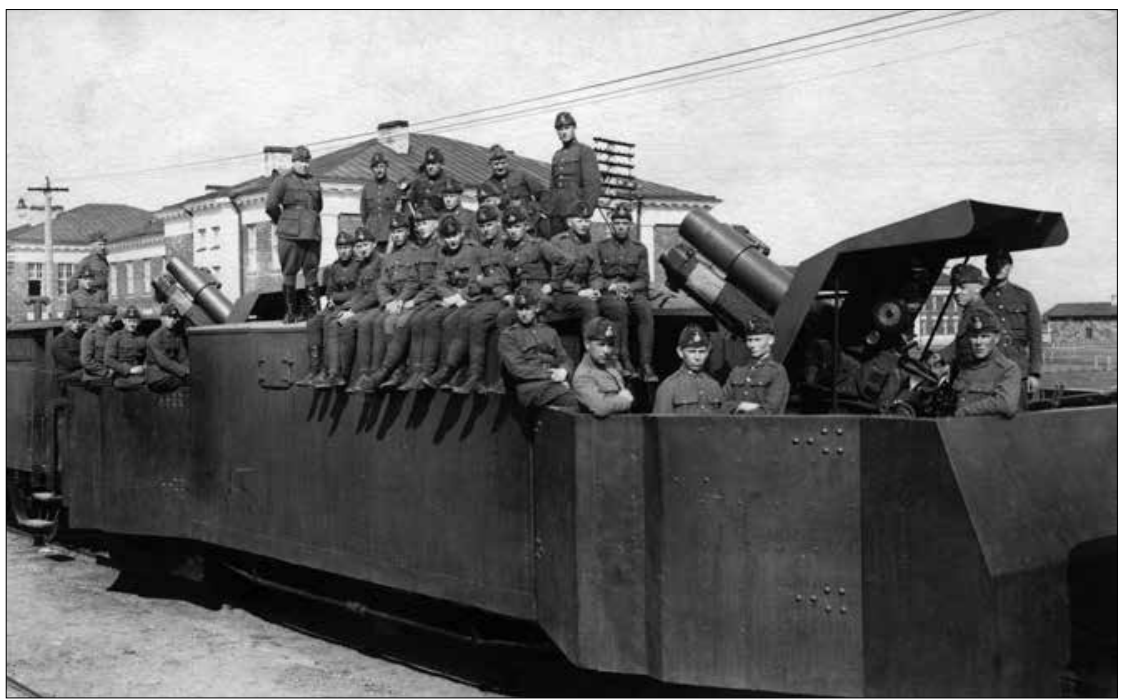

Estijos kariuomenès šarvuotojo traukinio igula ant artilerijos vagono, ginkluoto $120 \mathrm{~mm}$ haubicomis. XX a. 3-4 dešimtmetis Tavio Veilerio (Taavi Veiler) asmeninè kolekcija

Latvijos kariuomenès šarvuotieji traukiniai buvo pagaminti arba paimti kaip karo grobis taip pat Nepriklausomybès kovų (1919-1920) metu. Iš pradžių, tik kuriantis kariuomenei, buvo penki, vèliau - keturi plačiųjų geležinkelių šarvuotieji traukiniai.

Šarvuotąji traukinị Nr. 1 sudarè garvežys, 4 šarvuotieji vagonai ir 2 šarvuotosios platformos, ginkluotę - $88 \mathrm{~mm}$ jūrinè, $77 \mathrm{~mm}$ lauko ir $37 \mathrm{~mm}$, vèliau - 76,2 mm patrankos, 10 kulkosvaidžių. Nuo $1920 \mathrm{~m}$. traukiniui papildomai buvo skirtas garvežys, 6 kulkosvaidžiai ir $276 \mathrm{~mm}$ patrankos.

Šarvuotąjj traukinị Nr. 2 „Komunistu iznīcinātājs“ ( „Komunistų naikintojas“) sudarė garvežys, 4, nuo 1920 m. - 5 šarvuotieji vagonai, ginkluotę - 114,3 mm „Vickers“ (Didžioji Britanija) ir 105 mm haubicos, 9 kulkosvaidžiai.

Šarvuotasis traukinys Nr. 3, kurị sudarè garvežys ir 3 šarvuotieji vagonai, buvo ginkluotas $105 \mathrm{~mm}$ haubica ir $77 \mathrm{~mm}$ patranka, 6-7 kulkos-

ap,11 ap-12; 1938 m. Latvijos Respublikos kariuomenès dislokacijos schema Nr. 5, ten pat, lapas nenumeruotas. 


\section{Latvijos}

kariuomenès

šarvuotasis

traukinys

geležinkelio

stotyje.

1919 m.

Latvijos karo

muziejaus

(toliau - LKM)

rinkiniai,

inv. Nr. RM

2-79162/1557- $\varnothing$

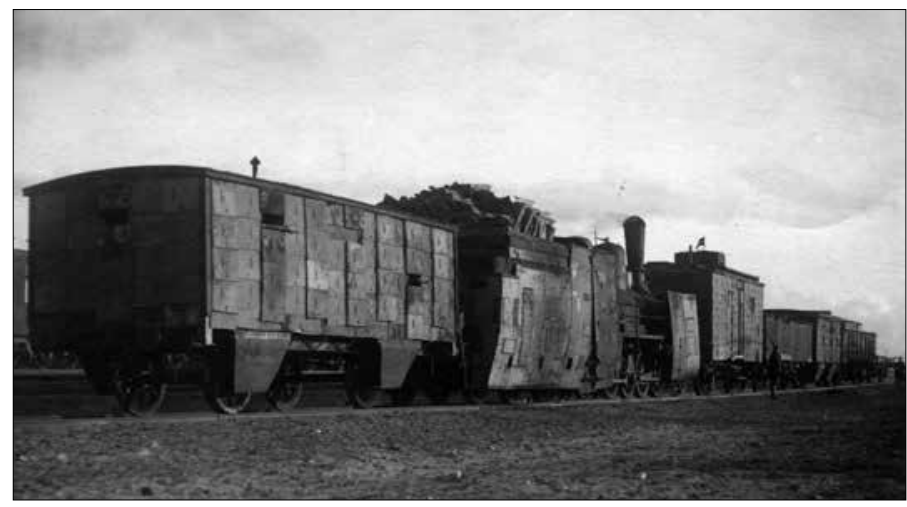

vaidžiais.

Šarvuotajj traukinị Nr. 4 sudare garvežys, 4 šarvuotieji vagonai, nuo 1919 m. pab. - dar 2 šarvuotojo traukinio Nr. 5 priskirti vagonai, ginkluotę - $277 \mathrm{~mm}$ ir $250 \mathrm{~mm}$ patrankos, 6 kulkosvaidžiai.

Šarvuotajji traukinị Nr. 5 „Kalpaks“ („Kalpakas“) sudarè garvežys, 2 šarvuotieji vagonai (1919 m. pab. - perduoti šarvuotajam traukiniui Nr. 4), 1 šarvuotoji platforma, ginkluota $305 \mathrm{~mm}$ jūriniu pabūklu ir 2 kulkosvaidžiais ${ }^{139}$. Dar žinoma, kad Latvijoje (Liepojoje) kurị laiką veikè siaurųjų geležinkelių šarvuotasis traukinys „Pikols“ („Pikolis“).

1920 m. visi Latvijos kariuomenès šarvuotieji traukiniai sudare šarvuotųjų traukinių divizioną (buvo dislokuotas Rygoje, vèliau - kitose Latvijos vietose), nuo $1926 \mathrm{~m}$. buvo ịtraukti ị šarvuotųjų traukinių pulko sudètị ${ }^{140} .1938 \mathrm{~m}$. šiame pulke buvo keturi šarvuotieji traukiniai ir artilerijos, kulkosvaidžių, inžinerijos ir ryšių padaliniai. Traukiniai buvo ginkluoti $105 \mathrm{~mm}$ haubicomis, $76 \mathrm{~mm}$ patrankomis, 7,7 mm „Vickers“ (Didžioji Britanija) kulkosvaidžiais. Šarvuotieji traukiniai buvo dislokuoti Rygoje, vèliau du - Daugpilyje, kiti du - Rezeknèje ${ }^{141} .1940$ m. pradžioje šarvuotųjų traukinių pulkas buvo išformuotas. Galiausiai 1940 m. vasarą Latvijos kariuomene, kuri buvo ịtraukta ị Raudonosios armijos sudètị,

\footnotetext{
${ }^{139}$ Bruṇoto vilcienu pulks. Latvieši vēstures likteṇdzirnās, <http://latviansmilhistory. blogspot.ru/2009/10/brunoto-vilcienu-pulks.html> [žiūrèta: 201501 15].

${ }^{140}$ N., Bruņoto vilcienu pulka 20 gadi, Latvijas kareivis, 1939, Nr. 127, 2 lpp.

${ }^{141} 1938$ m. Latvijos Respublikos kariuomenès dislokacijos schema Nr. 6, LCVA, f. 929, ap. 2, b. 1064, 1. 8 ap, lapas nenumeruotas.
} 


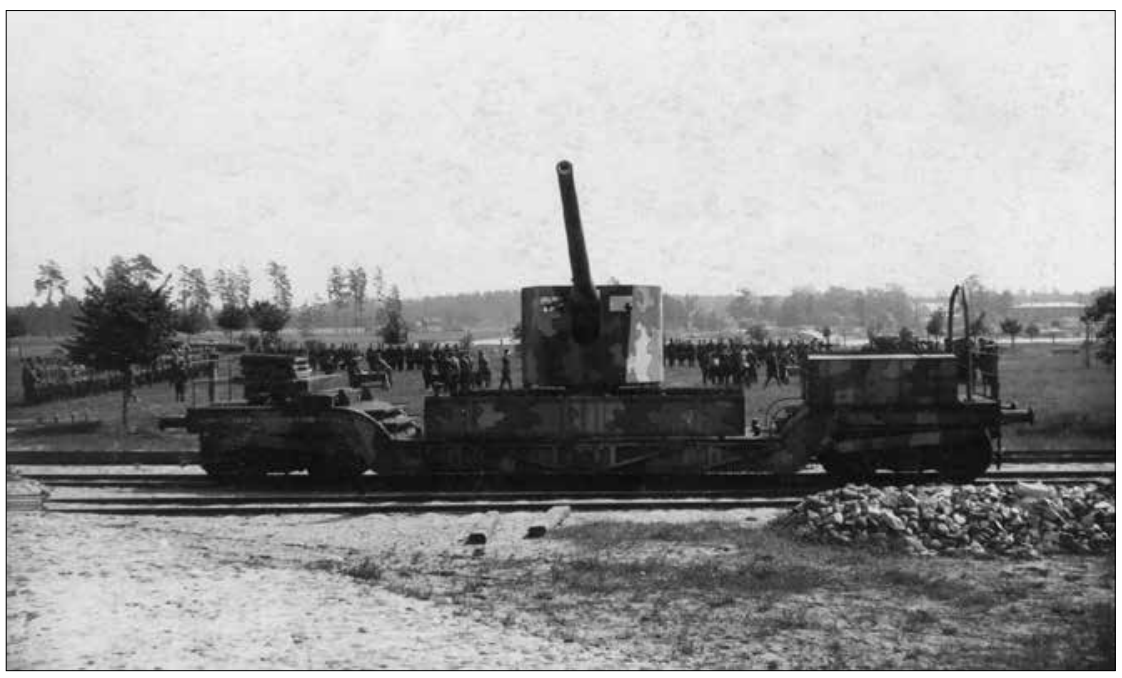

Latvijos kariuomenès šarvuotojo traukinio artilerijos platforma, ginkluota $152 \mathrm{~mm}$ kalibro M1877 modelio jūrine patranka „Canet“ (Rusija). XX a. 4-asis dešimtmetis LKM rinkiniai, inv. Nr. LKM 4-30650/8000-FT

turèjo du šarvuotuosius traukinius. Jie papildè SSRS Baltijos karinio laivyno 10-ąji atskirąji geležinkelių artilerijos divizioną ${ }^{142}$.

Lyginant Baltijos valstybių šarvuotuosius traukinius pasakytina, kad šarvuotụjų traukinių kaip tokio tipo kovinių dalinių pajègumus lèmé skirtinga Nepriklausomybės kovų patirtis ir karinès vadovybės pozicija. Jau 1918-1919 m. Estijos ir Latvijos kariuomenès šiose kovose panaudojo daugumą savo traukinių, skirtingai nuo Lietuvos kariuomenès, kurios šarvuotasis traukinys tik $1920 \mathrm{~m}$. pabaigoje dalyvavo kovose su lenkais. Taip pat tiek bolševikai, tiek bermontininkai fronte gana dažnai pasitelkdavo šarvuotuosius traukinius, kai kuriuos kaip karo grobi paèmè minètos šalys. Skyrèsi ir kovos pobūdis, karių, turèjusių profesinių žinių ir tarnavusių šarvuočių daliniuose, patirtis, likusių nuo karo riedmenų skaičius.

Šių „tvirtovių ant bėgių“ Estijos ir Latvijos karinè vadovybė atsisakyti neskubėjo, nes šie traukiniai turejo nemažą mobilumo, šarvuotės ir ginkluotès pranašumą, galejjo remti kitus karinius dalinius, netgi būti jų jud-

${ }^{142}$ М. Коломиец, Бронепоезда Великой Отечественной. „Сухопутные броненосць““ Красной Армии, Москва, 2010, с. 53. 

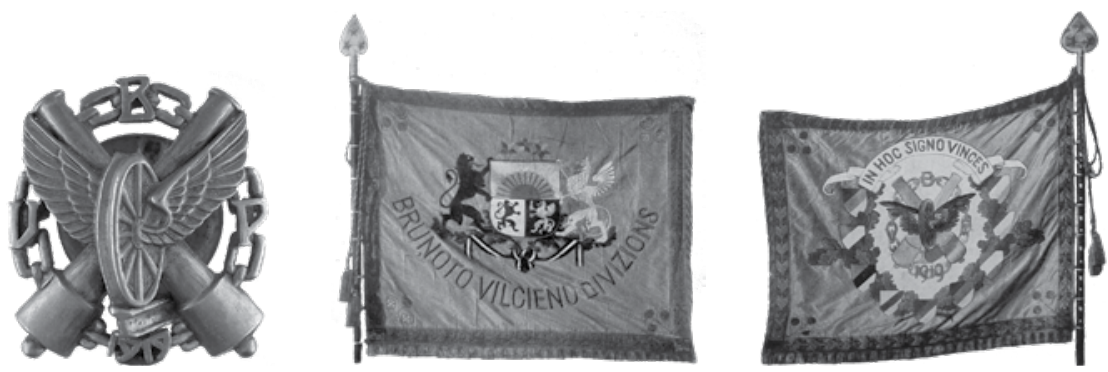

Latvijos kariuomenės šarvuotųjų traukinių karių antkrūtinis ženklas (XX a. 3-4 dešimtmetis) ir šarvuotụjų traukinių diviziono vèliava (apie $1925 \mathrm{~m}$.)

Autoriaus asmeninè skaitmeninè kolekcija

riomis aprūpinimo bazėmis ir t. t. Galimybès panaudoti šiuos traukinius priklausè nuo geležinkelių tinklo. Labiausiai išplètotą plačiojo ir siaurojo geležinkelių tinklą turèjo Latvija, gerokai retesnị (net už Lietuvos) - Estija, tačiau šis veiksnys neturèjo ịtakos šarvuotụjų traukinių dalinių raidai.

Nepriklausomybès kovose Baltijos valstybių kariuomenès susidūrè su bolševikų, bermontininkų ir lenkų (tik Lietuvos kariuomené $\dot{e}^{143}$ ) šarvuotaisiais daliniais, taip pat ir šarvuotaisiais traukiniais. Tačiau šiame straipsnyje pateikiami tik trijų Baltijos valstybių kariuomenių šarvuotụjų traukinių pagrindiniai duomenys, kadangi, palyginti su šiomis šalimis, ypač Nepriklausomybès kovų metu (1918-1921 m.), Lenkijos kariuomenè turèjo labiau išplètotą geležinkelių tinklą, daugiau šarvuotụjų traukinių (per 50), klasikinę, tačiau nuoseklią organizacinę struktūrą (divizionų, pulkų), sukomplektuotą personalą, galingesnę šarvuotę ir panašią ginkluotę. $1931 \mathrm{~m}$. vyko šarvuotųjų traukinių dalinių modernizavimas, dẻl to pasikeitè dalinių struktūra, personalo sudètis ir funkcijos. Šie šarvuotieji traukiniai dalyvavo ir Antrajame pasauliniame kare ${ }^{144}$.

Nepriklausomybės kovose Baltijos valstybių kariuomenių šarvuotųjų traukinių reikšmė ir funkcinis panaudojimo efektyvumas buvo didžiausias, tačiau taikos metu daugiausia dèl finansavimo, pasikeitusių karybos

${ }^{143}$ Žinoma, kad 1920 m. rudenị Lietuvos teritorijoje veikè Lenkijos šarvuotieji traukiniai „Pederevskis“ / „Generolas Želigovskis“ (lenk. „Paderewski“ / „Generał Żeligowski“) ir „Mirtis“ (lenk. „Śmierć“).

${ }^{144}$ T. Krawczak, J. Odziemkowski, Polskie pociagi pancerne $w$ wojnie 1939, Warszawa, 1987, s. 9-20, 23-35, 172-205. 
tendencijų ir pačios kariuomenès poreikių perskirstymo, skiriant daugiau dèmesio šarvuotiesiems automobiliams ir lengviesiems tankams, šarvuotụjų traukinių įtaka sumažèjo, tačiau, priešingai nei Lietuva, kitos kaimyninès valstybès jų neatsisakè, bet, sumažinusios skaičių, juos modernizavo, perskirstė pajégumus ir funkcijas.

\section{IŠVADOS}

1920 m. sausị pradètas, o rugpjūčio 25 d. buvo baigtas formuoti pirmasis Lietuvos kariuomenès šarvuotasis traukinys „Gediminas“. Jo igula rugsejji ir spali Suvalkų fronte dalyvavo kovose su lenkais. „Gediminas“ fronte vykdè žvalgomąsias ir paramos funkcijas, o taikos metu saugojo strateginius objektus, dalyvavo manevruose, pratybose ir mokymuose.

Visą laiką, kol funkcionavo šarvuotųjų traukinių koviniai daliniai, juos sudarè dvi pagrindinès dalys - kovinè ir bazinè. I kovinę dalị iejjo prekiniai garvežiai, 1-4 keturašès ir dviašès artilerijos platformos, ginkluotos patrankomis ir haubicomis, 1-2 kulkosvaidžių vagonai, ginkluoti kulkosvaidžiais, 1-2 motorinė ir rankinè šarvuotosios drezinos, skirtos žvalgybai vykdyti. Bazinę dali sudarẻ keliolika rusiškų ir vokiškų keturašių, triašių ir dviašių keleivinių I-II, III ir IV klasès ir prekinių vagonų, kontrolinių platformų. Bazinis sąstatas buvo bendras visam traukiniui arba daliniui, jis kovos veiksmuose nedalyvaudavo, bet buvo naudojamas apsaugai ir paramai užtikrinti.

Šarvuotieji traukiniai buvo ginkluoti įvairių kalibrų prancūziškomis ir vokiškomis (angliškomis) patrankomis, vokiškomis haubicomis ir kulkosvaidžiais. Šarvuotieji traukiniai buvo nudažyti prancūzišku, vèliau vokišku kamufliažu arba tik slepiamąja spalva, o atskiroms užduotims vykdyti maskuojami medžiais ir šakomis. Ant traukinio garvežių ir vagonų šonų buvo pavaizduotas baltas Vytis raudoname fone, baltos spalvos dažais parašyti traukinio ir vagonų pavadinimai ir numeriai.

Traukinio igula buvo ginkluota vokiškais, ispaniškais pistoletais, vokiškais ir britiškais šautuvais, karabinais ir granatomis. Iš pradžių kariai dèvejjo vokiškas ir (daugiausia) amerikietiškas, vèliau - tik lietuviškas karių uniformas su skiriamaisiais ženklais.

1921 m. rugpjūčio 1 d. šarvuotojo traukinio „Gediminas“ pagrindu 
buvo suformuotas šarvuotųjų traukinių pulkas. Jị sudarè trys traukiniai „Gediminas“, „Kęstutis“ ir „Algirdas“. 1924 m. sausio $1 \mathrm{~d}$. pulkas buvo reorganizuotas ị šarvuotụjų traukinių batalioną. Jị sudarẻ traukiniai „Gediminas“ ir „Kęstutis“. 1927 m. rugsèjo 16 d. šarvuotųjų traukinių batalionas buvo performuotas i kuopą, ją sudarè tik "Gediminas“. $1935 \mathrm{~m}$. rugpjūčio $14 \mathrm{~d}$. buvo išformuotas paskutinis šarvuotasis traukinys. Šarvuotieji traukiniai buvo dislokuoti Kaune (Žemojoje Fredoje, Žemuosiuose Šančiuose ir Linksmakalnyje), nuo 1925 (1927) m. - Radviliškyje.

Lietuvos kariuomenès šarvuotieji traukiniai galejo būti priskiriami vidutinių šarvuotųjų traukinių tipui, bet dydžiu niekada neprilygo nustatytam standartui. Performuojant ir išformuojant šarvuotuosius traukinius (dažniausiai dèl brangios eksploatacijos ir trūkstamo finansavimo), jų riedmenys buvo perduoti 2-ajam artilerijos pulkui, 2-ajam inžinerijos batalionui ir Geležinkelių valdybai.

Estijos ir Latvijos kariuomenėse šarvuotụjų traukinių daliniai buvo pradèti formuoti anksčiau nei Lietuvoje - 1918-1919 m. - ir funkcionavo visą Nepriklausomybès laikotarpi, juos sudarè daugiau traukinių. Šių šalių šarvuotieji traukiniai buvo geriau aprūpinti ir pasirengę vykdyti kovines paramos ir žvalgybos funkcijas.

Iteikta $2016 \mathrm{~m}$. rugpjūčio $1 \mathrm{~d}$. 


\title{
LES TRAINS BLINDÉS DE L’ARMÉE LITUANIENNE 1920-1935
}

\author{
Lieutenant dr. Andriejus STOLIAROVAS \\ Brigade d'infanterie mécanisée de l'armée lituanienne "Loup de fer »
}

La formation du premier train blindé de l'armée lituanienne, le " Gediminas », a commencé le 18 janvier et s'est achevée le 25 août 1920. Son unité a participé dès septembre et octobre sur le front de la Suvalkija aux combats pour l'indépendance contre les Polonais. Le "Gediminas " remplissait au front les fonctions de reconnaissance et de soutien au combat, et, en temps de paix, il protégeait les sites stratégiques, participait aux manœuvres, exercices et entraînements.

Le train blindé comprenait deux parties principales : la partie de combat et la partie de base. La partie de combat possédait des locomotives de série, une à quatre plateformes d'artillerie à quatre ou deux essieux, armées de canons et d'obusiers, un ou deux wagons à mitrailleuses, armés de mitrailleuses, et une ou deux draisines, motorisée ou manuelle, blindée ou non, pour effectuer la reconnaissance. La partie de base comprenait une dizaine de wagons russes et allemands à quatre, trois ou deux essieux pour les passagers de classe I-II, III et IV et les marchandises qui permettaient à l'unité de se loger (officiers en classe III et soldats en classe III, toilettes), étudier (classes), travailler (quartier général, administration, loge de la garde), préparer les repas et manger (cuisine et cantine), se détendre (mess) et se soigner (dispensaire). Cette partie comprenait également des wagons de marchandises à usage spécifique pour les entrepôts et les ateliers, ainsi que des plateformes de contrôle avec le matériel ferroviaire (rails, outils) et des outils d'assistance. Le convoi de base était commun à tout le train ou l'unité qui ne participait pas aux combats mais était utilisée pour assurer protection et soutien.

Les trains blindés étaient armés avec des canons français et allemands (anglais) de différents calibres, des mitrailleuses et obusiers allemands. Les trains blindés étaient peints avec un camouflage français, puis allemand, ou simplement une couleur de dissimulation, et ils étaient masqués avec des arbres et des branches pour effectuer certaines missions. Un Vytis blanc sur fond rouge était représenté sur les côtés des locomotives et des wagons des trains, les noms et numéros des trains et des wagons étaient écrits à la peinture blanche.

L'unité du train était armée de pistolets allemands et espagnols ainsi que de carabines, grenades et fusils allemands et britanniques. Au début, les soldats portaient des uniformes allemands et (surtout) américains, puis, uniquement 
des uniformes lituaniens avec des insignes distinctifs.

Le $1^{\mathrm{er}}$ août 1921, sur la base du train blindé « Gediminas » a été constitué le régiment des trains blindés. Il comprenait trois trains : «Gediminas », « Kęstutis » et "Algirdas ». Le $1^{\text {er }}$ janvier 1924, le régiment a été réorganisé en bataillon des trains blindés qui comprenait les trains « Gediminas » et "Kęstutis ». Le 16 septembre 1927, le bataillon des trains blindés a été réorganisé en compagnie et il comprenait seulement le "Gediminas ». Le dernier train blindé a été retiré le 14 août 1935. Les trains blindés étaient stationnés à Kaunas (dans les quartiers de Žemoji Freda, Žemieji Šančiai et Linksmakalnis) puis, à partir de 1925 (1927), à Radviliškis.

Les trains blindés de l'armée lituanienne pouvaient être classés dans la catégorie des trains blindés moyens, mais, par leur taille, ils n’ont jamais atteint la norme établie. Lorsque les trains blindés ont été reconfigurés et retirés (le plus souvent à cause de leur exploitation chère et d'un manque de financement), leur équipement roulant a été transféré au $2^{\mathrm{e}}$ régiment d'infanterie, au $2^{\mathrm{e}}$ bataillon de génie et à la direction des chemins de fer, tandis que le matériel militaire restant a été attribué non seulement aux unités de combat, mais aussi aux ateliers locaux et mobiles.

Dans les armées estonienne et lettonne, des unités des trains blindés ont constituées plus tôt qu'en Lituanie (1918-1919), elles ont été en activité pendant toute la période de l'indépendance, c'est-à-dire jusqu'en 1940, et comprenaient plus de trains. Les trains blindés de ces pays étaient mieux équipés et préparés pour remplir les fonctions de soutien au combat et de reconnaissance. 


\title{
ARMOURED TRAINS OF THE LITHUANIAN ARMED FORCES 1920-1935
}

\author{
Lieutenant dr Andriejus STOLIAROVAS \\ Mechanized Infantry Brigade Iron Wolf \\ of the Lithuanian Armed Forces
}

The formation of the Lithuanian armoured army train, Gediminas, whose crew participated in the independence battles with the Poles in September and October on the Suwalki front, started on 18 January 1920 and was completed on 25 August 1920. Train Gediminas conducted exploratory and combat support functions at the front, and in peacetime guarded strategic facilities, and took part in manoeuvres, exercises and training.

The armoured train consisted of two main parts - the basic and the combat parts. The combat part included locomotives, 1-4 four-axle and biaxial artillery platforms armed with cannons and howitzers, 1-2 machine gun carriages armed with machine guns, 1-2 motor and manual armoured and non-armoured railcars designed to conduct reconnaissance. The basic part included a dozen Russian and German four-axle, two-axle and three-axle passenger cars of I-II, III and IV class and freight cars to accommodate the unit's team (I-II class rooms for army officers, III class rooms for soldiers, a washroom), learning (classes), working (headquarters, office, the guard), cooking and eating (kitchen and dining room), entertainment (officers club), medical treatment (outpatient department), and various special purpose freight cars for storage and workshops, control platforms with railway materials (rails, tools) and aids. The basic formation was common to the whole train or units, which did not participate in combat actions but was used to ensure protection and support.

Armoured trains were equipped with various calibre French and German (English) cannons, howitzers and German machine guns. Armoured trains were painted in French and later in German camouflage, or only in camouflage colours or for individual tasks - masked by trees and branches. The White Vytis on a red background was depicted on the sides of locomotives and cars, and the names and numbers of trains and cars were written in white paint.

The train crew was armed with German, Spanish pistols, German and British guns, shotguns and grenades. At first, soldiers wore German and (mostly) American, and later only Lithuanian military uniforms with insignia.

On 1 August 1921, the regiment of armoured trains, based on the armoured 
train Gediminas, was formed. It consisted of three trains - Gediminas, Kęstutis and Algirdas. On 1 January 1924, the regiment was reorganized into the armoured train battalion. It consisted of the Gediminas and Kestutis trains. On 16 September 1927, the armoured train battalion was transformed into a squadron, and consisted of only the Gediminas train. On 14 August 1935, the last armoured train was disbanded. Armoured trains were deployed in Kaunas (Žemoji Freda, Žemieji Šančiai ir Linksmakalnis), and from 1925 (1927) - in Radviliškis.

Armoured trains of the Lithuanian army could be attributed to the type of medium armoured trains, but never equalled the standard in size. During reshaping and disbanding of armoured trains (usually due to their expensive operation and lack of funding), their vehicles were transferred to the 2nd Artillery Regiment, 2nd Engineering Battalion and the Railway Board, and the remaining military inventory was attributed not only to combat units, but also to local and mobile workshops.

Formation of armoured train units of the Estonian and Latvian armed forces began earlier than in Lithuania - in 1918-1919 and they functioned during the entire period of independence, namely until 1940, and consisted of more trains. Armoured trains in these countries were better equipped and prepared to carry out reconnaissance and combat support functions. 